UNIVERSIDADE DE SÃO PAULO

INSTITUTO DE PSICOLOGIA

DEPARTAMENTO DE PSICOLOGIA CLÍNICA

EMERSON FIGUEIRÊDO SIMÕES FILHO

\title{
Manejo de metáforas em psicoterapia analítico-comportamental
}

São Paulo 
UNIVERSIDADE DE SÃO PAULO

INSTITUTO DE PSICOLOGIA

DEPARTAMENTO DE PSICOLOGIA CLÍNICA

EMERSON FIGUEIRÊDO SIMÕES FILHO

\section{Manejo de metáforas em psicoterapia analítico-comportamental}

(Versão original)

Dissertação apresentada ao Instituto de Psicologia da Universidade de São Paulo como parte dos requisitos para a obtenção do grau de Mestre em Psicologia.

Área de Concentração: Psicologia Clínica

Orientadora: Profa. Dra. Sonia Beatriz Meyer

São Paulo 
AUTORIZO A REPRODUÇÃO E DIVULGAÇÃO TOTAL OU PARCIAL DESTE TRABALHO, POR QUALQUER MEIO CONVENCIONAL OU ELETRÔNICO, PARA FINS DE ESTUDO E PESQUISA, DESDE QUE CITADA A FONTE.

Catalogação na publicação

Biblioteca Dante Moreira Leite

Instituto de Psicologia da Universidade de São Paulo

Simões Filho, Emerson Figueirêdo.

Manejo de metáforas em psicoterapia analítico-comportamental / Emerson Figueirêdo Simões Filho; orientadora Sonia Beatriz Meyer. -São Paulo, 2014.

$83 \mathrm{f}$.

Dissertação (Mestrado - Programa de Pós-Graduação em Psicologia. Área de Concentração: Psicologia Escolar e do Desenvolvimento Humano) - Instituto de Psicologia da Universidade de São Paulo.

1. Metáforas 2. Delineamento experimental 3 . Terapia analíticocomportamental 4. Comunicação verbal 5. Teoria das molduras relacionais 6. Ansiedade I. Título.

BH301.M4 
FOLHA DE APROVAÇÃO

Emerson Figueirêdo Simões Filho

Manejo de metáforas em psicoterapia analítico-comportamental

Dissertação apresentada ao Instituto de Psicologia da Universidade de São Paulo como parte dos requisitos para a obtenção do grau de Mestre em Psicologia.

Área de Concentração: Psicologia Clínica

Orientadora: Profa. Dra. Sonia Beatriz Meyer

Aprovada em :

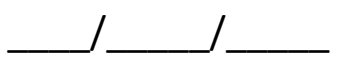

Banca Examinadora:

Prof. Dr.

Julgamento:

Assinatura:

Prof. Dr.

Julgamento:

Assinatura:

Prof. Dr.

Julgamento:

Assinatura: 


\section{AGRADECIMENTOS}

A quem nunca me deixou fraquejar ou desistir nas minhas empreitadas pela vida, minha mãe, Gladys. Sempre se fez presente para me dar apoio e me ensinou, com sacrifícios e exemplos, aos "trancos e barrancos", do que se trata a genuinidade do amor.

À Sonia, minha orientadora, pelos conselhos valiosos e por se colocar sempre à disposição apesar da minha não tão correspondente. Por cada empurrão, apoio, e sim, até cobranças sempre pertinentes.

À minha "vó" Iracy, quem com toda sua simplicidade e pureza encoraja-me no dia a dia a batalhar.

Ao meu avô Eujácio, talvez o maior exemplo de guerreiro e batalhador que eu tenha tido, que (lindamente) se emocionava cada vez que contava sua sofrida trajetória.

Ao meu pai, Emerson, de quem herdei o nome e possivelmente uma série de outras coisas, como criticidade e perseverança.

Ao meu irmão Leo, com quem aprendo aos poucos como é ter um amigo como irmão. Sou mais do que grato por esse.

Ao meu irmão Diego, que apesar de toda sua teimosia e peculiaridades consegue ser um cara bem bacana e companheiro. Deve ser bem difícil conciliá-las! Mas ele consegue.

À minha pequena irmã Lis, que me mostra o lado belo da vida cada vez que vejo ou apenas ouço seu riso, por exemplo. Entristece-me não poder estar próximo dela, fisicamente, todos os dias.

Ao meu tio Humberto. Embora não tenha tido o tempo que gostaria de ter tido ao seu lado, sempre o considerei e o considerarei especial. Se hoje eu sei o que é aceitação, e posso atribuir a alguém isso, é a ele.

À Mercedes Cunha Carvalho, por tamanho incentivo à minha imersão na Psicologia, sobretudo no Behaviorismo Radical, e que, um dia, disse que eu estava realizando o seu sonho. 
Ao Denis e ao Beto, por me acolherem de forma tão afetuosa e por me estenderem a mão nos momentos mais difíceis da minha vida - exemplos de companheirismo, de profissionalismo, de caráter... Do que há de mais humano.

À Roberta, por ter acreditado em mim com tamanha graciosidade e competência, interessantemente ao mesmo tempo.

À Yara, pela paciência e contribuições mais que relevantes, especialmente na formulação do projeto de pesquisa.

Ao Bernardo, que gostaria muito de ser chamado aqui de "Deus", mas não, não será. Mesmo assim, preciso reconhecer, sem ele, não conseguiria terminar este trabalho. Um amigo de grande estima. Embora "a pessoa mais quinta-série" que conheço.

Ao Dante, por se mostrar tão disposto a me receber em nova empreitada, desde o primeiro dia em que pus os pés em São Paulo. Que exemplo de amor ágape, não?

Ao Candido, pelas discussões metodológicas mais que valiosas e pelas sugestões de livros. Uma pena que não pude aproveitar tanto o George Orwell! Mas sim, foi e é fonte de inspiração. Ambos.

Ao Pedro e ao Victor, mais que parceiros de cursos e congressos, amigos queridos, espero que de longa data! Tão diferentes e opostos, quase que complementares, mas igualmente importantes e prezados por mim.

À Gabi Akemi (meu pandinha!), por todas as piadas, risadas inconfundíveis, tardes (e feriados!) de estudos e trabalhos, mas, sobretudo, pelo apoio. Uma grande amiga que sou muito grato por tê-la conhecido.

À Dani (Dadalto), uma grande amiga que tive o prazer de conhecer, embora há tão pouco tempo, tão profundamente.

À Natália e à Darlene, que se prontificaram tão delicadamente em me ajudar, apesar do deveras irritante bordão da última, "nós já conversamos sobre isso antes", que ela insiste que é "nós já tivemos essa conversa".

Ao Pedrinho. Sem dúvidas um dos meus grandes amigos. Por tudo que um dia eu pude conhecer nele ser especial. Por todas as noitadas de bebidas, de abraços e beijos que lhe dou (que ele não gosta, mas eu dou assim mesmo), sorrisos... Por cada piada sem graça que ele 
conta (eu realmente não acho graça em 99\%, mas ele insiste em contar... Sim, possivelmente a doce intermitência). E por ter se disposto tão prontamente a simplesmente me ajudar em tudo que eu poderia precisar, e estar por perto quando mais precisei.

Ao Marc, um dos caras mais incríveis e únicos com quem tenho o prazer de compartilhar a vida há quase 20 anos. Um irmão. E claro, falastrão e fácil de provocar também, o que me é extremamente prazeroso. Um dia ainda hei de publicar o seu livro!

Ao Carlito, Marcelinho, Deco, Felipe, Rodrigo, João, Maraivan... Esqueci alguém? Caveiras! Ao único e inigualável Barreto(s), um grande cara, embora ele não saiba o quanto. Ao me ver doente, sem dormir e trabalhando (sim, nessa dissertação), por exemplo, se prontificou sem hesitar a fazer um café da manhã (e o sanduíche ainda era bom!) e a ir na farmácia por mim.

Ao Jan, um dos caras mais hiperativos que conheço e que se provou um grande colega de pósgraduação e parceiro de clínica.

Ao Fernando Cassas, por confiar em mim, na minha capacidade como profissional, e me dar grandes modelos de como ser um.

Ao grupo de pesquisa da USP do laboratório de terapia comportamental, pelas reuniões, cafés (imprescindíveis, não?), discussões e "estrelas no lattes".

À Tau, quem tanto me ajudou (imagino que sem saber até!) a pensar detalhes do delineamento (tá bom vai, como medir a estabilidade da VD ao longo das fases do procedimento).

À Mi... Minha doce colega de mestrado. Quem sempre me surpreende, quase cotidianamente. Como alguém tão doce, gentil e aparentemente frágil pode ser tão forte! Uma guerreira! Perto dela, me sinto até apequenado, tamanha a garra dessa menina, o que me leva a lutar ainda mais, pelo exemplo. Já senti até medo (tá, exagerei) certa vez em que ela discutia com o mecânico de uma oficina na qual estava o seu carro.

À Laís, por todas as conversas interessantíssimas sobre feminilidade, discussões de gênero, igualdade, convenções sociais, preconceitos... Essa menina/mulher vai longe!

Ao grupo de pesquisa do Paradigma, pelos momentos lúdicos e de descontração, somados as reuniões e discussões calorosas. 
A Ismael, Plínio, Nelinho, Ramón, Fábio, Thiago, Rodrigo, Diego Dantas, Breno, Ana, tia Valéria, Luiza (vida!), Sanjuan, Mestre Marcus, Diogo, Ju, Karine, Uirá, André, Ciro, Tico, toda a família Brige Borges, dinda Erbene, Mila, Lara, Mateus, Isadora... A todos que um dia compartilharam comigo conversas, olhares, opiniões, risadas, gestos, carinhos, afetos, amizades e amor... Se hoje, sou quem sou, e escrevo essa dissertação, devo isso a cada um de vocês.

E, sobretudo, à Bruna Rubik. A quem reservo os agradecimentos em pensamentos - diários. 


\title{
RESUMO
}

\begin{abstract}
Simões Filho, E. F. (2014). Manejo de metáforas em psicoterapia analíticocomportamental. Qualificação de Mestrado. Departamento de Psicologia Clínica. Instituto de Psicologia. Universidade de São Paulo. São Paulo.
\end{abstract}

O entendimento do comportamento verbal (ou simbólico) e sua aplicação aos problemas comportamentais é importante para a análise clínica do comportamento pelo fato de o comportamento verbal humano ser pervasivo. Ou seja, humanos, ao serem verbalmente capazes, interagem com o ambiente, e processos verbais se tornam uma fonte de regulação comportamental. Considerando a psicoterapia como eminentemente verbal, entende-se como necessário a condução de pesquisas que abordem a complexidade do comportamento verbal no ambiente terapêutico. Embora metáforas, uma forma de intervenção verbal, tenham sido utilizadas por terapeutas analítico-comportamentais, nem sempre são claras as vantagens ou elucidados os efeitos que tal manejo traria. Esta pesquisa investigou, num delineamento experimental de caso único A-B-A-B na clínica, os efeitos do manejo de metáforas orientadas para valores na psicoterapia analítico-comportamental em um cliente com queixas ligadas à ansiedade. Os resultados foram comparados e correlacionados da categorização das sessões segundo o SiMCCIT - Sistema Multidimensional para a Categorização de Comportamentos na Interação Terapêutica e a qualidade das relações estabelecidas pelo cliente, com os resultados do EAS-40 e do BAI. Sugere-se que o manejo de metáforas evocou um estabelecimento de relações maior por parte da cliente no momento em que metáforas eram manejadas, embora os dados sejam pouco conclusivos. $\mathrm{O}$ uso de observações repetidas e contínuas, a avaliação da linha de base e o critério de estabilidade nesta e para as mudanças nas fases, assim como a replicação direta, permitiram demonstrar confiabilidade e contribuíram para a validade interna da pesquisa.

Palavras-chaves: metáforas, delineamento experimental de caso único, pesquisa de processo, terapia analítico-comportamental, comportamento verbal, teoria das molduras relacionais, ansiedade 


\begin{abstract}
Simões Filho, E. F. (2014). Manejo de metáforas em psicoterapia analíticocomportamental. Qualificação de Mestrado. Departamento de Psicologia Clínica. Instituto de Psicologia. Universidade de São Paulo. São Paulo.

The understanding of verbal (or symbolic) behavior and its application to behavioral problems is important for the clinical behavior analysis due to verbal behavior pervasiveness. While being able to verbally interact with the environment, human's verbal and cognitive processes become a source of behavioral regulation. As psychotherapy is considered eminently verbal, it is understood as necessary conduct researches that address the complexity of verbal behavior in this context. Although metaphors, a form of verbal intervention, are being used by behavioral therapists, advantages or effects of the management of them would bring are not always clear. This research investigated, in a single case ABAB experimental design, the effects of the management of oriented values' metaphors in a behavior therapy on a client with complaints related to anxiety. The results were compared and correlated with the categorization of sessions using the SiMCCIT, the quality of the relations established by the client on then, and the results of the EAS-40 and BAI. It is suggested that the management of metaphors evoked a greater establishment of relations by the client at the time that metaphors were handled, although the data are still inconclusive. The use of repeated and continuous observations, the evaluation of the baseline and the stability criteria on this and in the changes of the phases, as well as direct replication, have demonstrated reliability and contributed to internal validity.
\end{abstract}

Keywords: metaphor, single-case experimental design, psychotherapeutic processes, behavior therapy, verbal behavior, relational frame theory, anxiety 


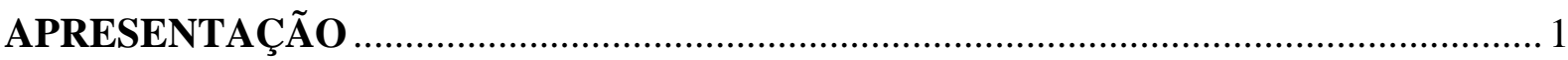

RELATOS DA HISTÓRIA DA(S) TERAPIA(S) COMPORTAMENTAL(IS) NO

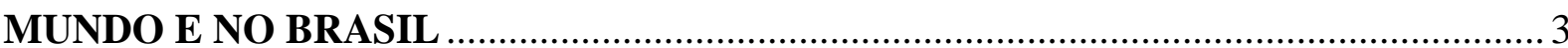

O DESENVOLVIMENTO DE PESQUiSAS DE PROCESSO E DE RESUltado NA PSICOTERAPIA, A PRODUÇÃO DE EVIDÊNCIAS E TERAPIA

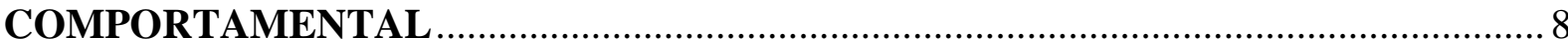

COMPORTAMENTO VERBAL, TEORIA DAS MOLDURAS RELACIONAIS E O USO E RECOMENDAÇÕES DE INTERVENÇÕES METAFÓRICAS NAS

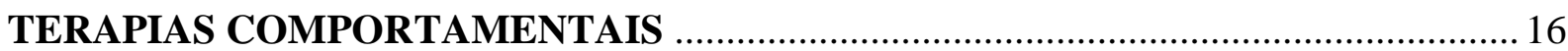

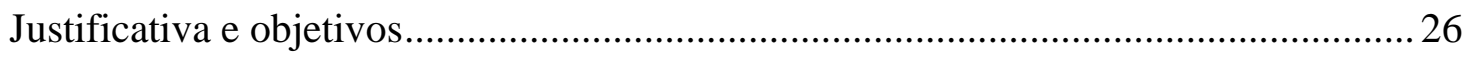

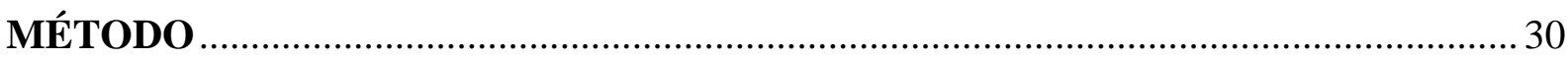

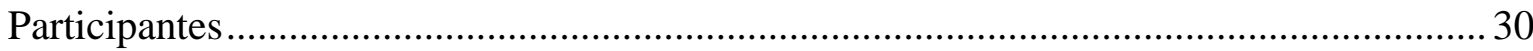

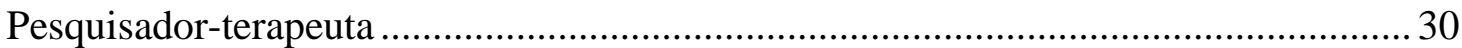

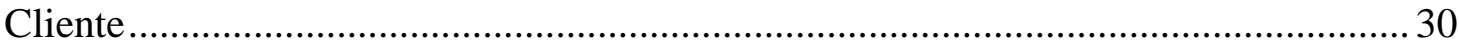

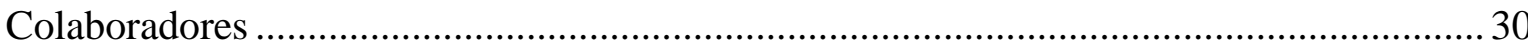

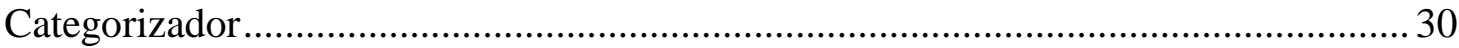

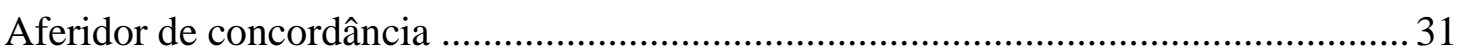

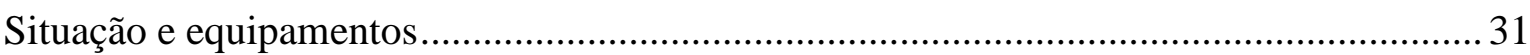

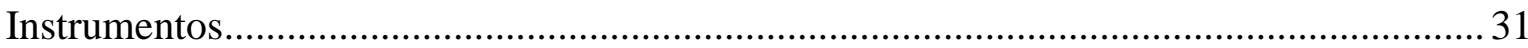

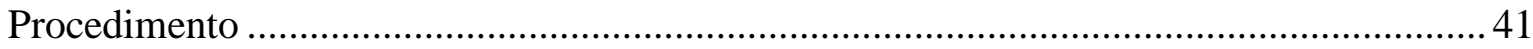

1) Seleção dos participantes .................................................................................... 41

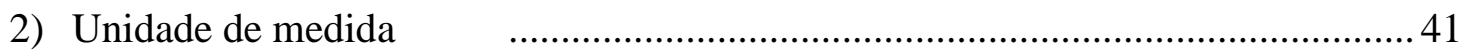

3) Procedimento experimental .............................................................................. 42

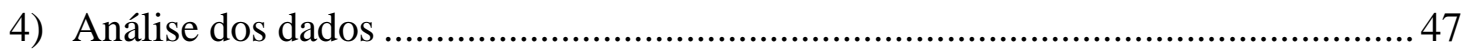

Concordância entre observadores .................................................................................. 47 


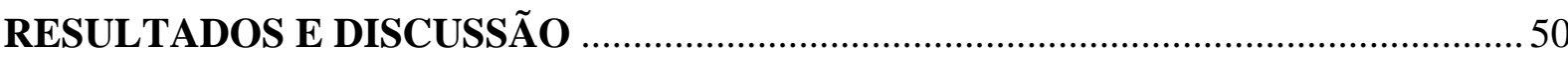

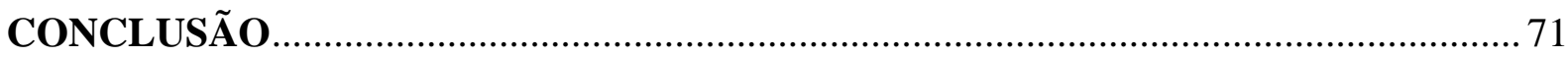

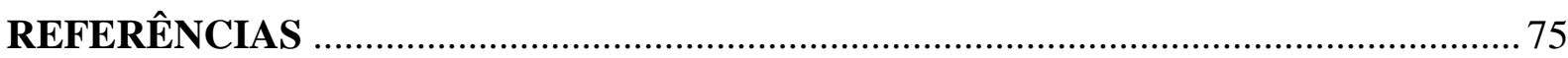

ANEXO 1 - Termo de consentimento livre e esclarecido para clientes …......................... 80

ANEXO 2 - Termo de compromisso e responsabilidade …........................................... 82

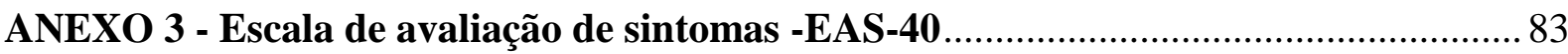

ANEXO 4 - Inventário de ansiedade de Beck - BAI ....................................................... 86

ANEXO 5 - Metáforas orientadas para valores utilizadas na pesquisa ......................... 87

ANEXO 6 - Resumo de Categorias do eixo 1 do SiMCCIT - Sistema Multidimensional de Categorização de Comportamentos na Interação Terapêutica................................. 95 


\section{LISTA DE TABELAS}

Tabela 1. Categorias do SiMCCIT do Eixo I referentes aos comportamentos verbais vocais de terapeuta e cliente

Tabela 2. Qualificadores das relações estabelecidas pela cliente

Tabela 3. Caracterização do manejo da metáfora do esquiador da ACT de acordo com o SiMCITT

Tabela 4. Resultados do Inventário de Ansiedade do Beck (BAI) por fase do procedimento.

Tabela 5. Resultados da Escala de Avaliação de Sintomas EAS-40 por fase de procedimento experimental 68 


\section{APRESENTAÇÃO}

O presente trabalho teve como finalidade, de um modo geral, estudar metáforas, ou, o uso dessas em um ambiente clínico. E passou por uma série de mudanças e refinamentos até essa versão definitiva.

Originalmente, o capítulo 1, "Relatos da história da(s) terapia(s) comportamental(is) no mundo e no Brasil", tinha como título "Breve histórico da terapia(s) comportamental(s)". Os dois "s" entre aspas referiam-se às múltiplas propostas recentes que se designam terapias comportamentais. Contudo, na medida em que foi redigido, fez-se necessária uma adaptação do título. Cabe enfatizar: por mais que possa ter existido uma história da terapia comportamental ou das terapias comportamentais, aqui apresento o relato verbal das pessoas que a narram, ou, ainda o meu relato verbal do relato delas.

Neste, são apresentadas resumidamente perspectivas da história da terapia comportamental no mundo, paralelamente com a da terapia comportamental no Brasil, nomeada Terapia Analítico-comportamental, e como as pesquisas em comportamento verbal evoluíram ao ponto de permitir agora, no ambiente clínico, a manipulação experimental de metáforas. Afinal, como em um sistema explicativo avesso ao uso de metáforas é possível estudá-las?

No capítulo 2, "O desenvolvimento de pesquisas de processo e de resultado na psicoterapia, a produção de evidências e terapia comportamental", primou-se apresentar considerações sobre a produção de evidências na psicoterapia, de que maneira pensá-las, como pesquisas de resultado e processo, delineamento experimental de caso único, e como conciliá-las com a variável estudada. 
O capítulo 3 "Comportamento verbal, teoria das molduras relacionais e o uso e recomendações de intervenções metafóricas nas terapias comportamentais" apresenta os referenciais teóricos em que o manejo de metáforas na clínica analítico-comportamental pode se basear, bem como são apontados possíveis efeitos não-excludentes do manejo dessas. Neste, também são detalhados os objetivos e a as justificativas que sustentam essa pesquisa

No capítulo 4 "Método" são apresentadas detalhes do procedimento experimental, dos participantes e dos instrumentos utilizados no estudo, enquanto que no capítulo 5 os resultados e a discussão proveniente destes.

No capítulo 6 "Conclusão" pormenoriza-se as considerações finais deste estudo, bem como questões relativas à validade interna e externa da pesquisa frente a proposições metodológicas correntes na literatura clínica e analítico-comportamental. 


\section{RELATOS DA HISTÓRIA DA(S) TERAPIA(S) COMPORTAMENTAL(IS) NO MUNDO E NO BRASIL}

O termo terapia comportamental veio a ser utilizado pela primeira vez em um projeto de pesquisa de Skinner, em 1953. Entretanto, seu primeiro uso em publicação cientifica ocorreu em 1954, num artigo de Lazarus. Logo em seguida, este termo abarcaria três grupos distintos, que futuramente trariam as mais diversas implicações para esta terapia. Um nos EUA, outro na África do Sul, e mais um no Reino Unido (Reed \& Luiselli, 2009).

Não tardaria muito para que estes grupos viessem a ser chamados de "modificadores de comportamento", ou, segundo a divisão de Hayes em 2004, a primeira onda das terapias comportamentais. Como aponta Pérez-Álvarez (1996), o elemento em comum, entre estes grupos, seria uma teoria da aprendizagem operacionalmente definida em conformidade com paradigmas experimentais bem estabelecidos já nessa época.

A década de 70 e 80 foram marcadas pelo surgimento e predomínio do cognitivismo, das terapias consideradas mediacionais, e do esforço em integrá-las com o conhecimento produzido até então (seja pelos modificadores de comportamento, seja por autores que os antecederam, como Watson), vide as psicoterapias cognitivo-comportamentais. Ou, para Hayes (2004), as terapias da segunda onda. Pérez-Álvarez (2006) aponta que a terapia cognitivo-comportamental seria a terapia psicológica melhor representada no rol dos tratamentos psicológicos, pois teriam comprovado sua eficácia em estudos que permitiriam a comparação dos resultados desta com tratamentos farmacológicos.

Contudo, este autor evidencia que tal êxito teria sido ao custo de se adotar o modelo médico na psicoterapia, ou, modelo de déficit, “internalista, mecanicista e nosológico (nomotético) (Pérez Alvarez, 2006, p.162)”. Anteriormente, cabe notar, Foucault (1962/1994) já teria antecipado e discutiu, de modo similar, as implicações epistemológicas que tal adoção 
acarretaria ao questionar um "paralelismo abstrato" em que os saberes psicopatológicos vigentes naquela época estariam fundamentados.

$\mathrm{Na}$ década de 90, emergiu a análise comportamental clínica (clinical behavior analysis), ou, a terceira onda das terapias comportamentais segundo Hayes (2004). De acordo com Pérez-Alvarez (2006), tal ascensão é produto tanto do desenvolvimento da análise do comportamento, do behaviorismo radical, como um desdobramento da análise funcional, sobretudo no campo do comportamento verbal, por conta de limitações da terapia cognitivocomportamental.

No Brasil, a evolução das terapias comportamentais ocorreu de modo singular. Como bem evidencia Vandenbergue (2011), a terapia comportamental brasileira, nomeada de terapia analítico-comportamental, se desenvolveu "no seio da análise do comportamento (...)", e “apresenta grande semelhança clínica e filosófica com as terapias da terceira onda. Ambas são externalistas e se concentram na relação entre os encobertos (do cliente e do terapeuta) com as contingências interpessoais" (p. 39). Além disso, caberia apontá-las como sustentadas em princípios científicos, advindos principalmente da psicologia da aprendizagem, e, ao mesmo tempo idiográfica, voltada para casos individuais. Não à toa, características essas em comum com as ditas terapias comportamentais da primeira geração comportamental, ou, a modificação de comportamento.

Segundo Kovac, Zamignani e Avanzi (2009), "no Brasil, a Terapia AnalíticoComportamental tem origem na produção coletiva de terapeutas de diferentes regiões do país" (p. 321). Todavia, cabe ressaltar que, com o seu desenvolvimento e talvez devido essa produção coletiva supracitada, na última década a terapia comportamental no Brasil veio a ter quatro diferentes denominações, como assinala Costa (2011). A saber: terapia analíticocomportamental, terapia por contingências de reforçamento, terapia molar e de autoconhecimento e a psicoterapia comportamental pragmática. 
Por outro lado, de modo semelhante, com o desenvolvimento e enfoque em determinadas intervenções, a terapia comportamental no resto do mundo tem sido representada, dentre outras propostas, pela psicoterapia analítica funcional (FAP), terapia de aceitação e compromisso (ACT), terapia comportamental dialética (DBT), terapia de casal comportamental integrativa (Zettle, 2005).

Há de se assinalar que tal caracterização das terapias comportamentais não é um consenso, sobretudo no Brasil, em que o movimento da terapia comportamental não fora análogo ao resto do mundo. Segundo Kerbauy (2011), por exemplo, não há ondas ou gerações na terapia comportamental, e sim uma mudança natural, ou, o desenvolvimento do próprio conhecimento acerca do fenômeno comportamental na clínica.

Para Vandenbergue (2011), dado o movimento relativamente inverso de desenvolvimento da terapia analítico-comportamental no Brasil frente às terapias comportamentais no resto do mundo ou nos EUA, ou, o (1) endividamento das terapias comportamentais de terceira onda com as terapias cognitivas da segunda onda, e (2) o linguajar idiossincrático de tratamentos como a ACT, a terapia de aceitação e compromisso (Hayes et al, 1999), não caberia identificar a terapia analítico-comportamental como uma terapia comportamental da terceira onda. Contudo, em razão do externalismo e dos princípios científicos em comum citados acima, o conhecimento dessas terapias comportamentais, as brasileiras (no artigo em questão, este menciona a terapia analítico-comportamental) e as de terceira onda, pode ser considerado como intercambiável.

Semelhantemente, Costa (2012) considera que, ao menos a ACT, não se mostrou em nada incompatível com os fundamentos da terapia analítico-comportamental.

Kohlenberg et al. (2005) apontam ainda que o futuro dos modelos de terapias comportamentais parece ser uma combinação de elementos destas em intervenções 
individualizadas, uma continuidade da análise clínica do comportamento, ao menos no que tange à psicoterapia analítica funcional e terapia de aceitação e compromisso.

De todo modo, segundo Pérez Alvarez (2006) a terceira geração trouxe um "repensar contextual da psicologia clínica" (p. 165), ou ainda, um "retorno às raízes contextuais da própria terapia comportamental" (p. 166). Isto incluiria a psicopatologia, a avaliação, tratamento e reofereceria a análise funcional, agora também aos eventos privados. Nesta, residiria a diferença mais significativa em relação às outras gerações.

Cabe ressaltar que, dada a preocupação com a produção de conhecimento científico, a comprovação empírica, e o estabelecimento de linhas de pesquisas básicas (que a possibilitaria se distinguir dos demais conhecimentos produzidos na psicologia), a análise do comportamento não deu ênfase (ou não pôde dar?) a pesquisas em comportamento verbal na clínica (logo também em metáforas) até recentemente.

Alguns autores (Donahoe, 1998; Drash \& Tudor, 1991; Eshleman, 1991; Leigland, 1998) apontam dificuldades metodológicas como o principal empecilho para o avanço de pesquisas e estudos sobre comportamento verbal, tais como a manipulação de antecedentes e consequentes desse operante, ou, se a frequência seria uma medida adequada para mensurar a variável dependente.

Fidalgo (2011) aponta um aumento sistemático no número de publicações de teses e dissertações no Brasil com o tema comportamento verbal a partir de 1989, assim como uma mudança na produção de pesquisas descritivas e experimentais, ao ponto de que em 2002 o total de trabalhos experimentais superasse o total de trabalhos descritivos desenvolvidos. Nesse estudo a autora aponta que, dentre as 26 pesquisas (teses ou dissertações) clínicas sobre comportamento verbal no Brasil até 2007, dezesseis adotaram principalmente o método descritivo. 
Somente uma pesquisa clínica, Abreu e Silva, (2012), teve metáforas como variável independente. Contudo, a autora não mediu a estabilidade da variável dependente no delineamento ABA empregado. Esse estudo será detalhado no capítulo 3.

Atualmente, pode-se assinalar que com conhecimentos sobre processos comportamentais consolidados, abre-se a possibilidade de abordar temas talvez mais complexos, como o comportamento verbal, com uma nova ênfase, sob uma nova ótica, em diversos ambientes. Não apenas descrevê-los ou interpretá-los (Skinner, 1957), baseando-se em conhecimentos de pesquisas básicas, mas manipulá-los onde quer que estes possam vir a ocorrer. Isto é, controlá-los, baseando-se nas mais diversas evidências científicas (Blackledge 2003, Dymond et al 2010, Dymond e Roche 2012, Grow 2010, \& Torneke 2010). 


\section{O DESENVOLVIMENTO DE PESQUISAS DE PROCESSO E DE RESULTADO NA PSICOTERAPIA, A PRODUÇÃO DE EVIDÊNCIAS E TERAPIA COMPORTAMENTAL}

O surgimento do campo e da prática da psicoterapia pode ser dito como contemporâneo ao da psicologia, enquanto domínio da ciência. A primeira clínica psicológica data de 1896 (concebida por Lightner Witmer, na Pensilvânia), e, se considerarmos o surgimento do Psychologische Institut em Leipzig como marco para a constituição da psicologia enquanto ciência, em 1879, separa-se então aproximadamente dezessete anos (McReynolds, 1997, citado por APA, 2006).

Desde então, um quase infindável número de técnicas e práticas, por um lado, e de conceitos, linhas teóricas e abordagens, por outro, desdobraram-se em torno desse recém formado campo de conhecimento.

Paralelamente, vários tipos de pesquisa com diversos métodos empregados em psicoterapia têm sido realizados. Neste estudo, será dada ênfase às pesquisas de resultado $e$ pesquisas de processo. Ou, se e como funciona a psicoterapia, respectivamente.

As pesquisas em psicoterapia surgiram em meados dos anos 50, tendo como preocupação central os resultados que esta poderia oferecer. Isso se deveu principalmente à demanda por justificativas científicas, legitimação social, e questionamentos da prática da psicoterapia (Eysenck, 1952; Migone, 1996).

Naquela época, a solução fora a formulação de manuais que apresentassem minuciosamente os procedimentos terapêuticos indicados para cada tipo de caso, propondo intervenções padronizadas para problemas específicos, com um número definido de sessões e protocolos rígidos de intervenção. A eficácia desses protocolos era avaliada por meio de estudos com metodologia de comparação dos resultados dessas intervenções entre grupos, 
segundo o delineamento de ensaios clínicos randomizados, ou RCT (em inglês randomized controlled trials). Estes estudos vieram a ser chamados de pesquisas de resultado (Migone, 1996).

Contudo, embora houvesse alguma necessidade de sistematização do trabalho do psicólogo clínico, o que é importante para a replicação dos estudos, isso não implicava em ter por objetivo a padronização de um trabalho que lida, dentre outras coisas, com eventos privados e individualização de seus clientes.

Assim, novas críticas das mais diversas abordagens psicoterápicas surgiram em torno dessa possível solução, como: (1) a padronização e a manualização dos tratamentos serem possivelmente menos benéficos dos que os propostos individualmente, ou ainda, a rigidez dos manuais poderia prejudicar a relação terapêutica, ao enfatizar demasiadamente uma determinada técnica; e (2) o fato de que muitos procedimentos nessas pesquisas estariam dispostos sob o mesmo rótulo, como "terapia cognitivo-comportamental" e "psicoterapia psicodinâmica" (Chambless \& Ollendick, 2001; Pheula \& Isolan, 2007).

$\mathrm{Ou}$, ainda que tais pesquisas apontassem resultados e indicassem mudanças comportamentais e correlações, não necessariamente haveria causações. Demonstrar uma mudança não significaria que a intervenção (ou VI) testada a ocasionou (fora responsável pela alteração da VD) (Kazdin, 2007; Peuker, Habibzang, Koller \& Araujo, 2009).

Analogamente a essa linha de pesquisa de resultados baseada em manuais, por volta dos anos 70, pesquisadores passaram a investigar os mecanismos de mudança comportamental que decorrem da terapia clínica, no interior desta, de forma mais detalhada. Essa linha de investigação foi chamada pesquisa de processo. Nesta, se busca identificar regularidades do processo terapêutico por meio do estudo de relações de determinação recíproca entre comportamentos do terapeuta e do cliente (Greenberg \& Pinsof, 1986; Russel \& Trull, 1986). 
Embora historicamente ambas as linhas de pesquisa, de resultado e processo, fossem tidas como domínios separados, nas últimas décadas essa divergência tem sido revista e abandonada. Pesquisadores têm conduzido estudos denominados processo-resultado, ao entenderem ambos como complementares, um continuиm. Nesse sentido, o resultado pode ser medido ao longo do processo terapêutico, em muitos pontos do tratamento e no follow-up (Greenberg \& Pinsof, 1986).

De qualquer maneira, em 1993, a APA (American Psychological Association) divulgou um relatório em que nomeou uma Força Tarefa Presidencial em Prática Baseada em Evidências, com o intuito de definir e explicitar princípios da prática baseada em evidências na psicologia. Embora os benefícios gerais da psicoterapia tivessem sido estabelecidos por revisões meta-analíticas na década de 70, neste documento discute-se, por exemplo, a noção de que, em algumas "esquinas do sistema de saúde" estadunidense, os tratamentos psicológicos para um transtorno específico seriam inferiores (ou até ineficazes) ao tratamento farmacológico (APA, 1993).

Posteriormente, em 2006, foi feita uma recomendação para clínicos se valerem de uma "prática baseada em evidência na Psicologia (em inglês, EBPP)", defendida como a integração da melhor evidência de pesquisa disponível com a experiência clínica, no contexto das características do paciente, de sua cultura e suas preferências. (APA, 2006)

Recentemente, talvez por conta da noção apresentada em 1993, a APA (2013) divulgou uma nova resolução em que reapresenta tanto algumas definições, como o que seria psicoterapia, aliança terapêutica, tratamento, prática psicológica baseada em evidências, como reconhece a efetividade da psicoterapia. Nesta, esta associação lista uma série de estudos que comprovariam efetividade em: (1) diversas populações, de crianças a adultos; (2) com variadas condições, como transtornos de ansiedade, depressão, (3) diferentes contextos e ambientes; assim como relacionadas a (4) políticas de saúde, como a redução de uso de 
medicações e gastos em geral e um adesão de minorias étnicas e raciais ao tratamento. Embora conclua e ateste que a psicoterapia deva ser incluída em sistemas de saúde como uma prática baseada em evidências, a APA reconhece a especificidade de alcance, limitações e implicações da prática psicoterápica, e, que ainda não foram pesquisados igualmente todos os fatores que aumentariam ou diminuiriam a efetividade da psicoterapia.

Em resoluções anteriores, primeiramente em 1993, e depois revistos em 1998, a APA estabeleceu alguns critérios para que tratamentos baseados em estudos de caso único sejam considerados empiricamente validados. Para tal, estes deveriam ter uma grande série de estudos de caso único, $\mathrm{n}>9$, com um bom delineamento experimental e comparações com outros tratamentos. Ainda que, novamente, para serem considerados tratamentos bem estabelecidos, os estudos deveriam ser conduzidos com tratamentos manualizados. Ou, para serem considerados tratamentos provavelmente eficazes, ao menos uma pequena série de estudos (com n igual ou maior que 3) com delineamento de caso único que demonstrassem (1) ou que o tratamento foi superior a lista de espera, ou (2) fossem conduzidos pelo mesmo investigador, ou (3) demonstrassem efetividade embora os clientes fossem heterogêneos (APA, 1993; Chambless, 1998).

Não parece ser exatamente clara a razão da APA em estabelecer como superior a nove estudos para que um tratamento seja bem estabelecido. Ainda que se possa entender como uma busca por sistematização a exigência por um tratamento padronizado e manualizado, para que este venha a ser considerado bem estabelecido, e assim poder-se-ia estabelecer com uma maior precisão os efeitos da variável estudada, novamente há de se apontar que a rigidez dos manuais poderia vir a prejudicar a relação terapêutica, tanto ao enfatizar demasiadamente uma determinada técnica, como levar o tratamento a ser menos benéfico a um cliente específico, por conta da influência de inúmeras outras variáveis desse cliente específico possivelmente não consideradas no estudo original. 
Contudo, ainda que se possa entender dessa maneira, como uma busca por sistematização, mesmo assim, considerações acerca da produção de evidencias de um delineamento experimental não seriam contempladas nesses critérios acima da APA, como o sujeito como seu próprio controle.

Em se tratando de delineamentos experimentais de caso único, Smith (2012), numa revisão sistemática sobre o tema agregou uma série de considerações na literatura da área, indicando assim como estes poderiam ser combinados a fim de prover melhores evidências. Aparentemente, nesse trabalho o autor procurou apresentar e descrever de modo imparcial o estado da arte de tal metodologia de pesquisa na literatura da área nos últimos 10 anos, a fim de prover para pesquisadores quais as técnicas, medidas e métodos estariam sendo utilizados. Vale ressaltar que, até 2006, estima-se nessa revisão que $80 \%$ dos estudos de caso único se valeram exclusivamente da inspeção visual como método de análise dos dados coletados.

Adicionalmente, Kratochwill (2013), em um artigo que pode ser entendido como prescritivo, na medida em apresenta níveis de qualidade de pesquisas com delineamento experimental de caso único, recomenda: para um delineamento $\mathrm{ABAB}$ (ou de reversão) seriam necessárias quatro fases (em que na fase B a VI seria inserida e em A não) com ao menos cinco pontos em cada (ou cinco sessões), para "atender aos padrões", ou, ao menos três pontos em cada fase para "atender aos padrões com reservas".

Embora (ainda?) não haja um consenso entre esses pesquisadores sobre qual seria o melhor delineamento para uma pesquisa com metodologia de caso único, talvez a combinação de estratégias já consolidadas com o problema de pesquisa e variáveis do cliente possa ser ponderada em cada estudo, a depender então, da amostragem, dos objetivos da pesquisa, da variável independente, das técnicas de medidas e análise, dentre outros.

Ainda que tradicionalmente os métodos estatísticos fossem questionados pela análise do comportamento (por exemplo, Sidman, 1960), talvez por conta de pesquisas psicológicas 
que dependessem exclusivamente destes para apontar algum controle experimental e validade interna, Fisch (1998 e 2001) recomenda fortemente alguns procedimentos estatísticos, quase todos não dependentes de suposições paramétricas ou que infiram uma distribuição normal de variáveis, sobretudo em circunstâncias que limitariam o controle experimental e dificultariam a inspeção visual.

De todo modo, talvez a maior preocupação na área de pesquisa em psicoterapia seja uma busca por evidência científica, seja esta qual for, e a necessidade da articulação entre a pesquisa e a prática clínica.

Em relação à terapia comportamental, alguns autores sugerem que pelo seu comprometimento com a pesquisa experimental e básica, ou, por se privilegiar o método indutivo nessas pesquisas, a terapia comportamental, por princípio, seria baseada em evidências e por isso não necessitaria então ser pesquisada (Forsyth \& Hawkins, 1997; Eifert \& Plaud, 1998).

Contudo, com o boom de terapias que se declararam comportamentais, caberia investigar se de fato todas essas seriam sustentadas em evidências, ou, se as intervenções que estas se propõem a utilizar são igualmente efetivas (leia-se, possui forte validade externa) num contexto clínico, caso tenham se provado eficazes (i.e., possui forte validade interna) em pesquisas básicas ou aplicadas.

A divisão 12 da APA mantém atualizado um sítio (o http://www.div12.org/PsychologicalTreatments/treatments.html) no qual dispõe todos os tratamentos psicológicos considerados empiricamente suportados, voltados para o público em geral acessá-los, e como profissionais de saúde poderiam vir a obter treinamento para administrá-los. Até a presente data, cinco tratamentos referiam-se à terapia de aceitação e compromisso, incluindo um para ansiedade. 
Cabe ressaltar que, quanto à depressão, por exemplo, o Instituto Cochrane publicou em 2013 uma revisão sistemática com metanálise comparando achados das pesquisas das terapias de terceira onda com outras terapias psicológicas, como a terapia cognitiva. Embora este estudo considere como vieses a formação dos pesquisadores, e assim, possíveis conflitos de interesses, há de se ressaltar que, quanto ao follow-up, o tratamento oferecido pelas terapias de terceira onda demonstrou-se significativamente superior.

De uma maneira geral, caberia perguntar: o que caracterizaria uma terapia para que esta viesse a ser nomeada terapia de terceira onda, ou ainda, terapia de aceitação e compromisso, e, nestas, quais elementos assegurariam uma mudança comportamental, ou, a efetividade de um tratamento. Ou seria o "pacote completo"? Embora presente em alguns estudos e manuais da terapia de aceitação e compromisso, o manejo de metáforas então, caso esta terapia tenha sido considerada efetiva para um determinado transtorno, por exemplo, pode ser considerado sustentado por evidências? Se não, como este manejo poderia vir a ser?

A produção de evidências é uma demanda tanto científica quanto social. No Brasil, foi sancionada em 2011 a lei $\mathrm{n}^{\circ} 12401$ que prevê a incorporação no sistema de saúde pública do país, o sistema único de saúde (SUS), de tratamentos baseados em evidências, como eficácia e efetividade destes (Brasil, 2011).

Do ponto de vista científico, Zamignani (2007), destaca que investigações envolvendo a combinação de diferentes métodos de coleta e análise de dados podem garantir uma maior e mais completa compreensão de um fenômeno tão complexo quanto a psicoterapia.

Este mesmo autor (Zamignani, 2007) considera que estudar o processo de mudança, e não só os resultados, seria bastante consistente com o modelo de construção da abordagem analítico-comportamental, visto que a interação entre o indivíduo e o ambiente, o processo e o produto dessa interação (como defende Todorov, 2012), assim como os processos de aprendizagem, são seus objetos de estudo. Zamignani (2007) também reitera que uma das 
possibilidades de identificação de regularidades é a sistematização dos dados de observação em classes de comportamentos do terapeuta e do cliente, cujos critérios de sistematização seriam descritos em termos de categorias de registro de comportamentos. Dessa maneira, seria possível conduzir uma análise das relações entre essas categorias.

Dessa maneira, esse estudo irá se preocupar em medir resultados simultaneamente com medidas do processo da psicoterapia, para posteriormente compará-los e correlacionálos, de forma a permitir identificar a que resultado corresponde o processo estudado, ou, a variável independente da pesquisa. A saber, metáforas orientadas para valores. 


\section{COMPORTAMENTO VERBAL, TEORIA DAS MOLDURAS RELACIONAIS, E O USO E RECOMENDAÇÕES DE INTERVENÇÕES METAFÓRICAS NAS TERAPIAS COMPORTAMENTAIS}

Há várias razões em que a dimensão do comportamento verbal (ou simbólico), como sua interação com o comportamento humano não-verbal e implicações em problemas comportamentais, torna o seu entendimento crucial, sobretudo no campo da análise clínica do comportamento (Dougher, 2000; Hayes et al, 1999; Pérez Alvarez 2006 \& Tourinho 2006).

As razões envolveriam: (1) em muitos contextos, uma mudança comportamental é (e talvez somente possa ser) alcançada através de uma "interação verbal" (verbal exchange) entre cliente e terapeuta: (2) o comportamento verbal humano é pervasivo, ou seja, humanos verbalmente capazes interagem com o ambiente verbalmente, e esses processos verbais tornam-se uma fonte significativa de regulação ou mudança comportamental; e (3) um substancial corpo de evidências sugere que processos verbais modificam a função de outros processos comportamentais (Hayes et al, 2007).

Embora o comportamento verbal seja constituído de atividade neural e muscular, ele não poderia ser meramente reduzido a isto. Analogamente, culturas humanas envolvem comportamentos verbais, que por sua vez requerem falantes e ouvintes, e envolvem contingências entrelaçadas e práticas culturais, que produzem conseqüências para além dos produtos dos comportamentos individuais nesta cultura (Glenn, 1989).

Para Glenn (1989), dizer que um comportamento é verbal basicamente é afirmar que é um comportamento sob controle de outras variáveis, além das envolvidas na contingência direta. Enquanto que, para Catania (2006), o comportamento verbal é um modo excessivamente eficiente por meio do qual um organismo pode modificar o comportamento de outro. 
Semelhantemente, como pretende-se apresentar nesse capítulo, poder-se-ia pensar metaforizar como um comportamento verbal específico que produz consequências no ouvinte além da fala e dos sons emitidos pelo falante, já característicos dos demais comportamentos verbais.

Publicações explícitas sobre metáforas na análise do comportamento podem ser rastreadas (ao menos) até 1945, no artigo “A análise operacional de termos psicológicos" de Skinner. Desde então, dois sistemas explicativos que dariam conta desse fenômeno da linguagem, comportamento verbal (Skinner, 1957) e teoria das molduras relacionais (Hayes, 2001), foram desenvolvidos.

Ao descrever um dos modos como a comunidade sócio-verbal modela e gera respostas verbais a eventos privados, Skinner (1945) comenta como, através da indução de estímulos, uma metáfora de um falante frente a uma estimulação privada pode ser emitida e mantida sob reforçamento público desta comunidade.

Para Skinner (1957), uma metáfora é um tato estendido, uma abstração de uma propriedade em comum de dois ou mais tipos de eventos ambientais diferentes. Dessa maneira, uma dada descrição de um evento privado poderia remeter a uma estimulação pública similar, como por exemplo, ao utilizar-se de "pluma" para descrever estados corpóreos (possivelmente passageiros) relativos à felicidade. Ou ainda, em situações em que o falante não possua uma resposta "disponível”, ou correspondente a uma dada estimulação ambiental.

Quando um tato estendido metafórico é reforçado, e assim, estabilizado, ele permite isolar uma nova propriedade de estímulo ou grupo de propriedades outrora não identificadas pela linguagem da comunidade verbal do falante. Ou seja, pela extensão metafórica do tato, novas propriedades da natureza são constantemente trazidas ao controle do comportamento verbal. Assim, para Skinner (1957) o comportamento verbal seria muito menos efetivo caso a 
extensão metafórica não fosse possível, assim como a natureza dos eventos que a subjazem seria uma questão empírica.

Por outro lado, para este autor, na medida em que essa resposta verbal nova metafórica é emitida e reforçada, ela "deixa" de ser um tato estendido metafórico. Agora, ela poderia vir a estar sob controle da audiência, por exemplo, e não mais sob a estimulação privada única que a antecedeu.

Até mesmo quando uma dada resposta verbal, um tato não-estendido, estaria disponível ao falante, Skinner considera que haveria vantagens para este ao se utilizar de um tato metafórico, como evocar respostas emocionais no ouvinte.

Dentre os diversos autores e obras que recomendam e incentivam o uso de metáforas no ambiente clínico e seriam baseadas (ao menos) na taxonomia funcional proposta por Skinner (1957) destacam-se Kohlenberg e Tsai (1991) e Tsai et al. (2009), ambas obras da Psicoterapia Analítica Funcional (ou FAP, do nome em inglês Functional Analytic Psychotherapy). Nas referidas publicações, as metáforas são consideradas respostas verbais de causas múltiplas sob o controle parcial de variáveis sutis. Assim, os autores sugerem ao terapeuta especular se o uso de metáforas pelo cliente seria mais do que uma mera descrição dos eventos ocorridos na sessão, pois esta poderia caracterizar um "pedido oculto" (um mando disfarçado ou um tato impuro).

Dessa maneira, caberia ao terapeuta fazer suposições sobre os reforçadores ocultos de tal resposta verbal, quando o uso da metáfora fosse empregado pelo cliente, ou o terapeuta poderia se valer desta para levantar hipóteses, como ao solicitar relatos, descrições ou previsões de análise ao cliente, visto que tais respostas poderiam ser melhor compreendidas através do conhecimento do contexto e da história que levaram a sua ocorrência (Kohlenberg \& Tsai, 1991). 
Em 2009, Tsai e colaboradores também sugerem o uso da "metáfora do coração" por parte do terapeuta, com o intuito de ilustrar o ato de "se abrir", ou tornar-se vulnerável, que corresponderia a um comportamento envolvido em desenvolver uma relação íntima ou de proximidade.

Possivelmente se baseando em assertivas skinnerianas, dentre outras, Banaco (1999) afirma que os relatos verbais de clientes sobre eventos privados seriam dicas das contingências em vigor em seus ambientes.

Meyer et al (2008) corroboram a possibilidade da comunicação por metáforas pelos clientes sugerir que estes estariam em contato com uma variável importante a ser investigada, pelo terapeuta. Quanto às funções de mando ou tato (operantes verbais skinnerianos) de uma dada resposta verbal, estes ressaltam o fato de uma comunicação pelo cliente ser direta ou indireta, editada ou não, e, novamente, quais as possíveis variáveis de controle de uma resposta, dada a causalidade múltipla do comportamento verbal.

Contudo, como indica Maccorquodale (1970), apesar da análise skinneriana do comportamento verbal ser sustentada nos termos das suas relações de controle, todos os termos do seu aparato analítico básico serem empiricamente definidos e os cuidados com as restrições das ciências naturais, esta seria um "esforço interpretativo" (Skinner, 1957, p.11). Logo, para Maccorquodale, uma hipótese, apesar do próprio Skinner explicitamente não o considerar assim, na medida em que não recorreria a entidades explanatórias hipotéticas. Semelhantemente, para Kohlenberg (2005), a análise skinneriana seria prematura.

Para Stewart e Barnes-Holmes (2001), as limitações da noção skinneriana sobre metáfora residiriam no fato de não apresentarem as condições necessárias para que surjam os desenvolvimentos da extensão metafórica do tato, ou, como um repertório verbal complexo de metaforizar se desenvolveria de um simples repertório de abstração de propriedades formais de estímulos. Lipkens e Hayes (2009) afirmam que Skinner não considerou em seu estudo as 
analogias "puramente relacionais", ou, aquelas nas quais não haveria nenhum elemento físico em comum.

Entretanto, como Maccorquodale (1970) e Tourinho et al (2003) analisam, o comportamento verbal seria uma hipótese que teria seu mérito ao ser sustentada em conceitos empiricamente comprovados como eficazes na interpretação de fenômenos menos complexos (como o operante e a teoria do reforço), rica em evidencias observáveis. Segundo estes autores, a grande contribuição skinneriana para o comportamento verbal fora apontar o caráter operante da linguagem.

Recentemente, estudos sobre responder relacional arbitrariamente aplicável e a Teoria das Molduras Relacionais (RFT, do inglês relational frame theory), inspirados nas pesquisas sobre equivalência de estímulos, indicaram novas possibilidades que o manejo de metáforas poderia oferecer às terapias comportamentais. Segundo Tourinho (2012), a investigação do responder relacional derivado estendeu a compreensão sobre fenômenos outrora insatisfatoriamente abordados.

De acordo com a RFT, humanos verbalmente capazes, ou expostos a certas contingências de reforçamento que operam na comunidade verbal, treinos de múltiplos exemplares, demonstram responder também a relações arbitrárias. Para os autores que defendem esta teoria, a característica diferenciadora dos seres humanos seria justamente a habilidade de relacionar estímulos de modo arbitrário, sem que estes compartilhem propriedades formais entre si, a depender exclusivamente da presença de um contexto relacional específico (Hayes, 2001).

Paralelamente, Stewart e Barnes-Holmes (2001), num esforço de convergência, evidenciam como seria possível integrar essas duas propostas de linguagem, comportamento verbal e teoria das molduras relacionais. Para Skinner, uma das características do comportamento verbal seria a mediação, isto é, a consequência reforçadora última de uma 
resposta verbal depende da mediação de um ouvinte especialmente treinado para provê-la. E esse treino especial do ouvinte nada mais seria que o treino de múltiplos exemplares assinalado pelos proponentes da RFT.

Para Skinner (1953/2003), por meio de um treino de reforçamento diferencial, no qual são reforçadas respostas aos estímulos que partilham uma propriedade física similar $e$ simultaneamente não são reforçadas respostas aos estímulos que não contém tal propriedade, o responder de um indivíduo é colocado sob controle exclusivo dessa propriedade em comum.

Enquanto que, aprendemos a abstrair propriedades relacionais ao sermos expostos a uma história de reforçamento, um treino de discriminação condicional com múltiplos exemplares de pares de estímulos que variam em muitas propriedades, mas mantém-se constante aquela correspondente à relação a ser abstraída (Perez et al, 2014).

Para a RFT, através deste treino de múltiplos exemplares, seria modelado desde a infância um operante de ordem superior, o responder relacional arbitrariamente aplicável (RRAA). Basicamente, relacionar implicaria em responder a um evento por controle de outro. Esse fenômeno segundo os proponentes da RFT poderia ser representado por famílias de molduras relacionais, que remeteriam não apenas a relações de equivalência (ou igualdade, para a RFT), como a área equivalência de estímulos sugere, mas também a relações de oposição, maior que, menor que, diferente de, dentre outras. Dessa maneira o comportamento não seria meramente controlado por propriedades formais, pela contiguidade ou contingência direta. Funções (de estímulos) poderiam ser verbalmente transformadas (Hayes et al, 2007).

Dentre as propriedades do RRAA, a implicação mútua, implicação combinatória e transformação de função de estímulos. No que se refere ao estudo de metáforas, cabe destacar a última, a transformação de função. Em geral, por uma metáfora, seriam estabelecidas relações de coordenação e hierarquia entre determinados estímulos, ou, numa rede relacional, 
que permitiria rapidamente ao ouvinte discriminar uma propriedade formal entre eventos aparentemente muito diferentes.

Em se tratando de metáforas, a transformação de função entre este eventos seriam unidirecionais - a relação $\mathrm{B}$ é análoga à $\mathrm{A}$, mas a relação $\mathrm{A}$ não é necessariamente análoga à B, diferentemente de analogias, como apontam Stewart e Barnes-Holmes (2001), Törneke (2010) e Ruiz e Luciano (2012). E todos estes, assim como McCurry (1992), reiteram: ainda faltam respostas a questões empíricas relacionadas a este fenômeno.

Em suma, quatro são os elementos relevantes de uma metáfora de acordo com a definição da RFT: (1) duas relações de coordenação distintas; (2) a derivação de uma relação de coordenação entre essas relações; (3) a discriminação de uma relação formal entre essas duas relações de coordenação; e (4) a transformação de função de estímulos baseada nessa última relação formal (Foody et al, 2014).

Nesse sentido, e valendo-se da mesma sustentação teórica, Eifert e Heffner (2002) evidenciaram que o manejo de metáforas reduziu o relato de medo e "sintomas cognitivos" durante a inalação de gás carbônico $\left(\mathrm{CO}_{2}\right)$. Roche, Forsyth e Maher (2007) apontaram que intervenções baseadas na aceitação (dentre elas, metáforas) levaram a uma tolerância maior à dor ao se imergir as mãos em um compartimento com água gelada, enquanto McMullen et al (2008), por sua vez, demonstraram redução da avaliação da dor frente a um choque elétrico.

Na clínica, Wilson e Luciano (2002), em um manual da Terapia de Aceitação e Compromisso (ACT, do inglês acceptance and commitment therapy), consideram que o manejo de metáforas pelo terapeuta seria um dos métodos clínicos de transformação da função de estímulos.

Enquanto que Hayes, Strosahl e Wilson (1999) apontam que o uso de metáforas na clínica aumentaria a proporção que o comportamento do cliente que fica sob controle de reforçadores não-sociais. Para estes autores, por meio de verbalizações metafóricas, também 
seria possível abordar conteúdos difíceis, aversivos, com menos resistência ou defesas por parte do cliente.

Não obstante, Sturmey (2007) afirma que a incorporação do responder relacional arbitrariamente aplicável provê uma intervenção (clínica) mais flexível em um escopo consideravelmente maior.

Enquanto isso, no Brasil, apenas em 22 publicações podem ser encontradas a presença do termo metáfora, segundo Abreu e Silva (2012), além desta própria. Dessas 22, a maioria, $54,54 \%$, estariam ligadas à terapia infantil. Apenas outras três publicações remetiam ao comportamento do terapeuta de metaforizar, e foram classificadas por essa autora com os temas "relação terapêutica" e "análise funcional". Em "relação terapêutica", teriam como função diminuir a aversividade de algumas relações interpessoais, que, para Abreu e Silva (2012), remeteriam ao efeito evocativo emocional descrito por Skinner. No tema "análise funcional", metáforas constituiriam uma via de acesso às contingências de controle do cliente. Todas, sem exceção, seriam baseadas na análise skinneriana do comportamento verbal.

Abreu e Silva (2012) protagonizou também o primeiro estudo de caso (narrativo) no Brasil com o tema metáforas. Não houve manipulação experimental ou mensuração da estabilidade de variáveis dependentes e os achados de tal estudo convergem com as proposições skinnerianas.

Anteriormente, também no Brasil, Meyer (2000) questionou-se sobre quais os processos comportamentais envolvidos nas mudanças de comportamento observadas durante o período da terapia. E assinalou: "mudamos, em terapia verbal, o controle de estímulos, quando identificamos uma propriedade do estímulo discriminativo que controla uma resposta e tornamos mais salientes outras propriedades do mesmo estímulo, que controlam outras respostas" (p. 5). Sendo assim, cabe questionar, poderia então o uso de metáforas vir a ser um modo de tornar salientes essas outras propriedades do estímulo que controlariam a resposta? 
De todo modo, resumindo, sugere-se então cinco possíveis definições não excludentes dos efeitos que o manejo de metáforas na clínica poderia produzir:

1) um modo de tornar salientes na sessão outras propriedades do estímulo que controlaria o responder do cliente, uma estimulação suplementar;

2) um modo de evocar a análise de comportamentos-problema do cliente por este na sessão; ${ }^{1}$

3) um modo de evocar respostas emocionais no cliente, baseando-se em Skinner (1957);

4) um dos métodos clínicos de transformação da função de estímulos, como defendem Wilson e Luciano (2012).

5) uma maneira de lidar com conteúdos aversivos com menos resistência ou defesas por parte do cliente, tal qual Hayes, Strosahl e Wilson (1999) defendem.

Ainda na literatura da análise clínica do comportamento é apontado que, dentre outros comportamentos-problema, clientes com queixas de ansiedade recorrentemente engajam-se em situações com o intuito de eliminar ou reduzir a ansiedade, e isto faria parte do problema, na medida em que manteria o cliente continuamente eliminando um produto das contingências em vigor, sem de fato alterá-las. Dentre intervenções e modos de lidar com este perfil de clientes, uma conexão com valores é expressamente recomendada (Eifert \& Forsyth 2005).

$\mathrm{Na}$ ACT, valores têm sido defendidos como direções de vida escolhidas, globais, desejadas e verbalmente construídas. Desta forma, seriam pontos de partida para a construção da vida e de objetivos, assim como das metas da terapia (Luoma, Hayes \& Walser, 2007).

\footnotetext{
${ }^{1}$ Segundo a conceituação de caso da FAP, tais respostas do cliente sobre problemas comportamentais que ocorrem fora da sessão e não remeteriam a relação terapêutica, ao serem evocados na sessão, seriam classificados como O 1 (do inglês outsiders). Ao cliente lidar com estes abertamente na sessão, com o terapeuta, novamente segundo a racional da FAP e a depender da conceituação do caso, podem vir a configurá-los como um CRB 2, ou, um comportamento de melhora do cliente também apresentado em sessão.
} 
Assim como caberiam aos terapeutas orientados pela ACT o esclarecimento e a delimitação dos valores dos pacientes, embora não envolvam uma discussão crítica dos valores em si mesmos (i.e., se os clientes deveriam ter ou não um determinado valor).

Segundo Leigland (2005), um valor, poderia ser tido como uma operação motivadora estabelecedora, que estabeleceria como reforçador consequências imediatas que até então não selecionariam o comportamento do cliente (talvez por este produzir consequências muito atrasadas ou a longo prazo, por exemplo) e evocariam respostas direcionadas a tais consequências a longo prazo.

Michael (1982) aponta uma série de considerações sobre a definição de uma operação motivadora estabelecedora, como a correlação entre essas e a efetividade diferencial de um estímulo enquanto reforçador.

Simplificando, operações motivadoras momentaneamente aumentam ou diminuem a efetividade de um estímulo como reforçador. Logo, indiretamente aumentam ou diminuem a frequência das respostas que o produziriam dado o efeito estabelecedor e o efeito evocativo, respectivamente (Michael, 1993).

Entretanto, em se tratando de comportamentos verbais, como a enunciação de um "valor para a vida" em terapia, é evidente como dificilmente este pode ser tido como algo momentâneo. Assim, embora reconheça a possibilidade destes estabelecerem ou abolirem a eficácia de reforçadores (assim como outras funções de estímulos), Leigland (2005) reitera que, nestes casos, trata-se da verbalização de um tipo de regra, chamado augmenting. Segundo este autor, tal alteração (ou transformação) de função reforçadora da consequência imediata, por exemplo, derivaria da participação dessa resposta verbal em uma moldura relacional, e seria produto também de uma história presumida de treinos de múltiplos exemplares e reforçamento social mediado. 
Para Törneke, Luciano e Salas (2008), em vez de especificar contingências ou consequências, este tipo de regra alteraria o valor reforçador das consequências descritas ou implícitas/relacionadas nela, pela transformação de função de estímulos. Também permitiria governar um comportamento embora um indivíduo nunca tenha experienciado diretamente as consequências que este dado comportamento acarretaria, ou, engajar-se em comportamentos apesar de possíveis consequências aversivas em curto prazo.

Em suma, a orientação para valores por meio de metáforas "tornaria o trabalho duro valorizado", ao alterar o valor da consequência imediata. Por exemplo, evocaria respostas enfraquecidas no repertório de clientes que poderiam produzir poucos reforçadores a curto prazo e talvez negativos, mas, a longo prazo, estariam ligadas a reforçadores atrasados potentes e possivelmente positivos. Ou ainda, algumas metáforas facilitariam a formação de regras augmenting por clientes.

Por fim, Eifert e Forsyth (2005) entendem que comportamentos dirigidos a valores podem ser tidos como alternativas para o comportamento-problema de manejar ou tentar controlar a ansiedade.

\section{Justificativa e Objetivos}

Notadamente, o tratamento dado aos eventos privados (ou encobertos) pode ser considerado um dos fatores determinantes dos "caminhos percorridos" na história das terapias comportamentais. Como descrito por Skinner (1945) no início do capítulo, o estudo de metáforas está intimamente relacionado aos estudos dos eventos privados. Banaco (1999) já as apontou como uma via de acesso a estes. Poder-se-ia até conduzir uma análise histórica à luz do modo em que estes eram compreendidos, e possivelmente, apontar o seu entendimento 
como um dos fatores decisivos no desdobramento das inúmeras terapias comportamentais em voga na atualidade.

Ao ponderar então sobre o papel dos eventos privados e respostas encobertas, e o modo como o comportamento verbal pode gerar fontes originais de controle do comportamento humano não-verbal, Tourinho (2006) reconhece a necessidade de técnicas que abarquem o escopo de uma terapia eminentemente verbal.

Atualmente, destaca-se a recorrência da presença do termo metáfora na literatura psicológica, bem como a sugestão de seu uso em terapia comportamental. Todavia, nem sempre são claras quais as vantagens ou efeitos antevistos que tal manejo traria/anteciparia. Novamente, o uso de metáforas em psicoterapia analítico-comportamental pode ser considerado empiricamente validado? Ou "suportado?" Ou ainda, quais as possíveis mudanças comportamentais que estas poderiam produzir?

Ora, se a psicoterapia, como apontam (dentre outros) Pérez Álvarez (2006), Hayes et al (2007) e Tourinho (2006) é eminentemente verbal, não seria adequada a condução de pesquisas que abordassem a complexidade do comportamento verbal? Ou, que permitam ao psicoterapeuta manejá-lo de um modo efetivo em relação às metas estabelecidas no processo terapêutico?

Ou ainda, de que modo o emprego de metáforas por parte do terapeuta evocaria na sessão o estabelecimento de relações por parte do cliente, que por sua vez poderiam ser entendidas como comportamentos de melhora ou análises do porquê de seu comportamento estar ocorrendo e sendo mantido em determinadas situações? Haveria diferenças entre as possíveis relações estabelecidas pelo cliente após metáforas emitidas pelo terapeuta e relações formadas pelo cliente posteriormente à intervenções não-metafóricas? Desse modo, justificase um estudo sobre metáforas, e a maneira como essas podem vir a auxiliar na prática dos terapeutas. 
Cabe considerar que, como distinguiu a APA em 2006 (p. 274):

Intervenções específicas que não tenham sido submetidas a testes empíricos sistemáticos para problemas específicos não podem ser assumidas como eficazes ou ineficazes; elas seriam simplesmente não testadas até a presente data. No entanto, a boa prática e a ciência indicam este momento como oportuno para se testar as práticas psicológicas de uma forma que os operacionalize adequadamente, usando a metodologia científica apropriada (p. 274, tradução livre). ${ }^{2}$

Ou, nas palavras de Zamignani (2007), "entender como e porque o tratamento funciona pode proporcionar a maximização de seus efeitos e assegurar que seus aspectos críticos sejam generalizados para a prática clínica” (p. 2).

Paralelamente, Meyer (1995) indica a possibilidade de se valer de conhecimentos e técnicas advindas de outros campos ou abordagens psicológicas. Ao analista do comportamento, caso estas se provassem eficazes e produtivas, caberia analisar e explicar quais os processos comportamentais que justificariam tal uso.

Sendo assim, este trabalho apresentou como objetivo geral:

1) Investigar os efeitos do manejo de metáforas orientadas para valores no repertório de uma cliente diagnosticada com transtorno de ansiedade generalizada através de um delineamento experimental de caso único na clínica;

Os objetivos específicos foram:

1) Examinar as diferenças no processo terapêutico quando o terapeuta utiliza metáforas de clarificação de valores (VI) e quando não as usa, como por exemplo, um aumento na

\footnotetext{
${ }^{2}$ Specific interventions that have not been subjected to systematic empirical testing for specific problems cannot be assumed to be either effective or ineffective; they are simply untested to date. Nonetheless, good practice and science call for the timely testing of psychological practices in a way that adequately operationalizes them using appropriate scientific methodology.
} 
ocorrência e/ou duração da categoria "cliente estabelece relações" (VD), segundo o SiMCCIT - Sistema Multidimensional para a Categorização de Comportamentos na Interação Terapêutica (Zamignani, 2007), no repertório do cliente;

2) Avaliar a qualidade das relações estabelecidas pelo cliente no processo terapêutico (VD), tendo como critério a descrição verbal da resposta, consequências (imediatas ou a longo prazo), encobertos (sentimentos e pensamentos) e meios de solucionar problemas. 


\section{MÉTODO}

\section{Participantes}

Pesquisador-terapeuta: Nessa pesquisa, o pesquisador foi o terapeuta. Este é formado em psicologia e especialista em psicologia clínica analítico-comportamental, com quatro anos de experiência em psicoterapia na época da coleta. Considerou-se que a figura do pesquisador como terapeuta pôde vir a somar ao estudo na medida em que estaria sensível ao cliente e em quais momentos manejaria (ou não) a VI do estudo, avaliando em que ocasiões foram favoráveis e adequadas às mudanças de fases da pesquisa, e, sobretudo, ponderaria como alinhar os objetivos do trabalho com a condução de uma psicoterapia de acordo com as metas e valores do cliente.

Cliente: Participou deste estudo uma cliente adulta, do sexo feminino, selecionada por meio da triagem que ocorreu na clínica-escola de um instituto de formação de terapeutas analítico-comportamentais, e que apresentou um diagnóstico de Transtorno de Ansiedade Generalizada. A cliente preencheu um Termo de Consentimento Livre e Esclarecido (Anexo 1) que autorizou a participação na pesquisa, a filmagem, e o uso dos dados para fins de pesquisa.

\section{Colaboradores}

Categorizador: Nessa pesquisa foi selecionado um categorizador para dispor os resultados de uma maneira que facilitasse as análises dos dados. Este é psicólogo com formação em análise do comportamento e terapeuta analítico-comportamental com 
experiência prévia tanto em clínica, como com o SiMCCIT - Sistema Multidimensional para a Categorização de Comportamentos na Interação Terapêutica (Zamignani, 2007). Um Termo de Responsabilidade (Anexo 2) foi assinado para assegurar o sigilo das informações obtidas na coleta da pesquisa.

Aferidor de concordância: Para garantir a concordância dos dados obtidos nesta pesquisa, o pesquisador-terapeuta categorizou uma sessão da terapia, escolhida ao acaso.

\section{Situação e equipamentos}

As sessões foram realizadas em uma sala de uma clínica-escola em um instituto para formação de terapeutas, localizado na cidade de São Paulo. Essas sessões foram semanais e de aproximadamente 50 minutos. As sessões foram analisadas e categorizadas mediante uma planilha de Excel que permite uma análise das sessões terapêuticas e da contínua interação entre cliente e terapeuta, fornecendo informações referentes à frequência e duração das categorias do SiMCITT.

\section{Instrumentos}

Foram utilizados os seguintes instrumentos na coleta de dados a ser realizada:

- SiMCCIT - Sistema Multidimensional de Categorização de Comportamentos na Interação Terapêutica, desenvolvido por Zamignani e Meyer (2007).

Trata-se de um sistema para categorização e análise de comportamentos do terapeuta e do cliente, observados em sessão, cuja função é presumida a partir de sua forma gramatical 
(e.g., imperativa, interrogativa, etc.) e de sua relação com eventos imediatamente precedentes e subsequentes, e contexto de ocorrência.

Esse sistema foi desenvolvido para padronizar a categorização de comportamentos verbais de terapeutas e clientes na interação terapêutica. Para isso, o sistema conta com três eixos principais de análise e os dois primeiros eixos possuem qualificadores específicos. O Eixo I refere-se exclusivamente aos comportamentos verbais de terapeuta e cliente. O Eixo II refere-se à categorização dos temas abordados durante a interação. O Eixo III contém as categorias dos comportamentos motores. Recentemente, o SiMCCIT teve sua validade aparente, ou, sua capacidade de medição para o que este se propõe a medir, medida por Zamignani (2011).

Para a presente pesquisa foi selecionado apenas o Eixo I de análise, por auxiliar na categorização dos comportamentos verbais vocais existentes na interação Terapeuta-Cliente. As categorias relativas aos comportamentos verbais não vocais existentes no Eixo I, bem como os outros eixos não foram utilizados a princípio. No anexo 6 foram inclusos resumos das categorias utilizadas nessa pesquisa para facilitar a visualização dos dados arrolados no capítulo 5.

A seguir, na Tabela 1, são apresentadas as categorias presentes no Eixo I que se referem aos comportamentos verbais vocais de Terapeuta e Cliente. 
Tabela 1 - Categorias do SiMCCIT do Eixo I referentes aos comportamentos verbais vocais de terapeuta e cliente.

\begin{tabular}{|c|c|}
\hline Categorias das Respostas Verbais do & Categorias das Respostas Verbais do \\
Terapeuta & Cliente \\
\hline 1. SOLICITAÇÃO DE RELATO (SRE) & 1. SOLICITAÇÃO (SOL) \\
\hline 2. FACILITAÇ̃̃O (FAC) & 2. RELATO (REL) \\
\hline 3. EMPATIA (EMP) & 3. MELHORA (MEL) \\
\hline 4. INFORMAÇ̃̃O (INF) & 4. METAS (MET) \\
\hline 5. SOLICITAÇÃO DE REFLEXÃO (SRF) & 5. RELAÇÕES (CER) \\
\hline 6. RECOMENDAÇÃO (REC) & 6. CONCORDÂNCIA (CON) \\
\hline 7. INTERPRETAÇÃO (INT) & 7. OPOSIÇÃO (OPO) \\
\hline 8. APROVAÇÃO (APR) & 8. OUTRAS VOCAL CLIENTE \\
\hline 9. REPROVAÇÃO (REP) & 9. C SILÊNCIO \\
\hline 10. OUTRAS VOCAL TERAPEUTA & \\
\hline 11. T SILÊNCIO & \\
\hline
\end{tabular}

\section{Categorias das respostas verbais do terapeuta}

1. Solicitação de Relato (SRE): Terapeuta solicita ao cliente descrições sobre ações, eventos, sentimentos ou pensamentos. Inclui: 1.1. Solicitação de informações sobre fatos e 1.2. Solicitação de relato de respostas encobertas do cliente. Ocorre tipicamente em situações relacionadas a coleta de dados e levantamento de informações ao longo de qualquer etapa do processo terapêutico. 
2. Facilitação (FAC): Terapeuta emite verbalizações curtas ou expressões paralinguísticas durante a fala do cliente indicando atenção ou sinalizando a continuidade do relato do cliente. Inclui: 2.1. Verbalizações mínimas e 2.2. Expressões paralinguísticas.

3. Empatia (EMP): Verbalizações do terapeuta que indiquem acolhimento, aceitação, cuidado, entendimento validação da experiência ou sentimento do cliente. Tais verbalizações não têm um caráter específico, sugerindo aceitação do cliente sem validação ou julgamento. Inclui: 3.1. Nomeação e inferência de sentimento; 3.2. Normalização e validação de sentimentos; 3.3 . Exclamações e expressões de interesse; 3.4. Verbalizações e cuidados; 3.5. Auto revelações sobre experiências similares; 3.6. Validação de discordâncias o u críticas do cliente; 3.7. Humor; 3.8. Apoio; 3.9. Paráfrases e 3.10. Comentários de entendimento.

4. Informação (INF): Verbalizações nas quais o terapeuta relata eventos ou informa o cliente sobre eventos (que não o comportamento do cliente ou de terceiros). São verbalizações tipicamente associadas às intervenções "psicoeducacionais" e ao contrato terapêutico. Inclui: 4.1. Informações Factuais; 4.2. Explicações de eventos; 4.3. Descrição de regularidades ou padrões recorrentes a respeito de eventos; 4.4. Explicações teóricas e experimentais sobre eventos; 4.5. Informações sobre o contrato terapêutico; 4.6. Descrições de estratégias, de procedimentos ou do programa terapêutico e 4.7. Justificativas de intervenções.

5. Solicitação de Reflexão (SRF): Terapeuta solicita ao cliente qualificações, explicações, interpretações, análises ou previsões a respeito de qualquer tipo de evento. Diferentemente de solicitação de relato, na qual o terapeuta pede que o cliente apenas relate a ocorrência de eventos, sentimentos ou pensamentos, nesse caso o terapeuta solicita que o cliente analise ou estabeleça relações entre os eventos em discussão. Inclui: 5.1. Solicitação de análise; 5.2. Solicitação de avaliação; 5.3. Solicitação de previsão e 5.4. Solicitação de observação.

6. Recomendação (REC): Terapeuta sugere alternativas de ação ao cliente ou solicita o engajamento em ações ou tarefas. Inclui: 6.1. Conselhos; 6.2. Modelo; 6.3. Incentivo; 6.4. 
Estruturação da atividade (frase de entendimento) e 6.5. Permissão, proibição ou solicitação de parada.

7. Interpretação (INT): Verbalizações nas quais o terapeuta descreve, supõe ou infere relações causais e/ou explicativas (funcionais, correlacionais, ou de contiguidade) sobre o comportamento do cliente ou terceiros. Inclui: 7.1. Descrições de relações explicativas entre ações (do cliente ou de terceiros) e outros eventos; 7.2. Descrição de regularidades ou padrões recorrentes entre ações (do cliente ou de terceiros) e outros eventos ou ações; 7.3. Diagnóstico; 7.4. Devolutiva de avaliação padronizada; 7.5. Estabelecimento de sínteses; 7.6. Metáforas ou analogias explicativas; 7.7. Inferências; 7.8. Previsões; 7.9. Confrontações; 7.10. Normalizações e 7.11. Descrição de processo.

8. Aprovação (APR): Verbalizações do terapeuta que sugerem avaliação ou julgamento favoráveis a respeito de ações, pensamentos, características ou avaliações do cliente. Inclui: 8.1. Elogios ou avaliações positivas sobre o cliente; 8.2. Descrição de ganhos terapêuticos; 8.3. Verbalizações de concordâncias; 8.4. Pseudo discordância; 8.5. Relato de sentimentos positivos; 8.6. Exclamações e expressões de aprovação e 8.7. Agradecimentos.

9. Reprovação (REP): Verbalizações do terapeuta que sugerem avaliações ou julgamentos desfavoráveis a respeito de ações, pensamentos, características ou avaliações do cliente. Inclui: 9.1. Discordância; 9.2. Crítica; 9.3. Ironia; 9.4. Ameaça; 9.5. Paráfrase crítica; 9.6. Autorrevelações desafiadoras; 9.7. Relato de sentimentos negativos e 9.8. Advertência.

10. Outras Vocal Terapeuta (OUT): Inclui: 10.1. Verbalizações do terapeuta não classificáveis nas categorias anteriores; 10.2. Acertos ocasionais; 10.3. Recuperação de assunto e 10.4. Opiniões pessoais sobre eventos externos.

11. Silêncio (TSL): Esta categoria é do tipo estado (presente por um período de tempo) e deve ser utilizada no intervalo de tempo entre uma verbalização do terapeuta e a próxima verbalização do mesmo. 


\section{Categorias das respostas verbais do cliente}

1. Solicitação (SOL): Verbalizações nas quais o cliente apresenta pedidos ou questões ao terapeuta. Inclui: 1.1. Solicitação de informações e esclarecimentos; 1.2. Solicitação de avaliação; 1.3. Solicitação de recomendação; 1.4. Solicitação de procedimentos; 1.5 . Solicitação de asseguramento e 1.6. Apresentação da demanda.

2. Relato (REL): Cliente descreve ou informa ao terapeuta a ocorrência de eventos, ou aspectos relativos a eventos, repostas emocionais suas ou de terceiros. Nessas verbalizações o cliente não estabelece relações entre os eventos. Inclui: 2.1. Relato de informação sobre eventos; 2.2. Relato de eventos anteriormente registrados; 2.3. Relato de sentimentos e emoções; 2.4. Relato de estados motivacionais ou tendências a ação e 2.5 Julgamento ou avaliação.

3. Melhora (MEL): Verbalizações nas quais o cliente relata mudanças satisfatórias com relação à sua queixa clínica, problemas médicos e/ou comportamentos considerados inadequados ou indesejados (independentemente da concordância de ambos quanto à melhora). Inclui: 3.1. Relato de ganhos terapêuticos; 3.2. Relato de mudanças positivas no comportamento de terceiros; 3.3. Relato de autocontrole e 3.4. Relato de autoconsciência.

4. Metas (MET): Verbalizações do cliente em que há descrição de planos e/ou projetos para a solução de problemas trazidos como queixa na sessão. Inclui: 4.1. Planejamento de estratégias e 4.2. Proposta de ações futuras.

5. Cliente Estabelece Relações (CER): Verbalizações nas quais o cliente estabelece relações causais e/ou explicativas entre eventos, mesmo por meio de metáforas ou analogias. Inclui: 5.1. Estabelecimento de relações explicativas; 5.2. Identificação de regularidades, relações de contiguidade ou de correlação entre eventos; 5.3. Atribuição de diagnóstico; 5.4. 
Estabelecimento de síntese; 5.5. Inferências; 5.6. Previsão sobre eventos futuros; 5.7. Reflexões que conduzem a razões, a explicações ou a análises de consequências.

6. Concordância (CON): Verbalizações nas quais o cliente expressa julgamento ou avaliação favoráveis a respeito de afirmações, sugestões, análises ou outras respostas emitidas pelo terapeuta. Também fazem parte dessa categoria verbalizações do cliente que completam ou resumem as falas do terapeuta. Inclui: 6.1. Avaliações favoráveis sobre o terapeuta; 6.2. Relato de esperança; 6.3. Relato de satisfação; 6.4. Relato de seguimento de solicitação de reflexão; 6.5. Indicações de atenção; 6.6. Indicações de entendimento e 6.7. Exclamação de concordância.

7. Oposição (OPO): Verbalizações nas quais o cliente expressa discordância, julgamento ou avaliação desfavoráveis a respeito de afirmações, sugestões, análises ou outras respostas emitidas pelo terapeuta. Inclui: 7.1. Queixas ou reclamações sobre a terapia; 7.2. Relatos de descontentamento; 7.3. Indicações de contradição; 7.4. Relato de sentimentos negativos; 7.5. Ironia dirigida ao terapeuta; 7.6. Relatos de incredulidade; 7.7. Pedidos de interrupção; 7.8. Ameaças; 7.9. Recusas; 7.10. Desvios do assunto; 7.11. Recusas de elogio; 7.12. Relatos de não seguimento.

8. Outras vocal cliente: Verbalizações do cliente não classificáveis nas categorias acima, cumprimentos, despedidas, interrupções ou comentários ocasionais alheios à terapia. Inclui: 8.1. Acertos ocasionais; 8.2. Recuperação de assunto e 8.3. Outras respostas verbais do cliente.

9. Cliente silêncio: Esta categoria é do tipo estado (presente por um período de tempo) e deve ser utilizada no intervalo de tempo entre uma verbalização do cliente e a próxima verbalização do mesmo. 


\section{Para Análise do Estabelecimento de Relações pelo Cliente}

Para além da categorização prevista do SiMCCIT , a categoria CER, também teve os seguintes qualificadores analisados, para se considerar a completude, coerência e consistência das relações estabelecidas pelo cliente, como constam na Tabela 2, e, poder-se de algum modo comparar as relações estabelecidas pela cliente e se estas apresentavam diferenças de acordo com o procedimento experimental.

Utilizou-se uma versão modificada dos qualificadores desenvolvidos por Rodrigues et al (no prelo). Esta categorização divide os CER's em três grupos de acordo com o número de elementos que podem ser identificados no trecho da fala do cliente.

Os elementos que poderiam ser identificados na relação estabelecida pelo cliente poderiam ser: (1) Evento antecedente; (2) Resposta; (3) Evento consequente; (4) aspectos da história de reforçamento relevantes para explicar a função de um dado evento.

A Tabela 2 a seguir detalha os possíveis qualificadores (qualis) da categoria CER do cliente. 
Tabela 2: Qualificadores das relações estabelecidas pela cliente.

\section{QUALIFICADORES DAS VERBALIZAÇÕES DE ESTABELECIMENTO DE}

RELAÇÕES DE RODRIGUES ET AL (NO PRELO) MODIFICADO

Qualis1

Relações constituídas por premissas falsas, inconsistentes ou incoerentes ou, ainda que consistentes de forma isolada, a conexão estabelecida entre elas parecia pouco plausível, falaciosa ou frágil perante um exame lógico elementar. Foram incluídas nesta categoria explicações com base em eventos de ordem metafísica, relações mágicas ou supersticiosas, explicações que atribuíam causalidade exclusiva a eventos privados, ou, que não apresentaram mais de um elemento da tríplice contingência. Ressalta-se que, se um dos elos for um evento privado, este não poderia ser tratado como causa da ocorrência de uma classe de resposta.

Qualis2

Relações que apontam para premissas coerentes ou consistentes, mas que carecem de uma descrição mais aprofundada de parte das variáveis relevantes. Foram incluídas nesta categoria descrições que continham até dois elos da tríplice contingência. Se um dos elos fosse um evento privado, este não poderia ser tratado como causa da ocorrência de uma classe de resposta.

\section{Qualis3}

Relações baseadas em premissas válidas e consistentes. Foram incluídas nesta categoria descrições que continham os três elos da tríplice contingência. Se um dos elos fosse um evento privado, este não poderia ser tratado como causa da ocorrência de uma classe de resposta. 


\section{Escala de Avaliação dos Sintomas (EAS-40)}

O EAS-40 foi um instrumento adaptado por Laloni (2001) a partir de um estudo de validação para a população brasileira do instrumento SCL-90-R (Symptom Checklist-90Revised) (Derogatis, 1994, apud Laloni, 2001). A SCL-90-R é um inventário de autoavaliação a partir de uma escala Likert de cinco pontos, que avalia problemas psicológicos e sintomas psicopatológicos.Tem sido utilizada também como medida externa de melhora na avaliação de eficácia de drogas. Ao ser estudado para a população brasileira sofreu algumas adaptações e foi reduzida para uma escala de 40 itens avaliados com uma escala Likert de três pontos e denominada como EAS-40. Os 40 itens mencionados são divididos em quatro dimensões: Psicoticismo - avaliação de um contínuo entre psicose e depressão com sintomas de hostilidade e ideias paranóides; Obsessividade Compulsividade - repetição de pensamentos e ações, além de desconforto nas relações interpessoais; Somatização - sintomas de transtornos somáticos ou somatoformes; Ansiedade - avaliação tanto de ansiedade generalizada como ansiedade fóbica. Desse modo, a EAS-40 é capaz de identificar diferenças na população e foi utilizada na presente pesquisa como instrumento auxiliar de medida do comportamento externo do cliente ao longo do processo psicoterápico. A escala já foi validada para a população brasileira e aplicada em diversos estudos, apresentando atualmente indicadores de parâmetros de normatização. Além disso, a utilização deste instrumento permite aferir se os resultados obtidos na terapia seriam suficientes para esta vir a ser considerada como bem-sucedida ou não (Anexo 3). 


\section{Inventário de Ansiedade de Beck (BAI)}

Traduzido e validado por Cunha (2001) para a realidade brasileira, trata-se de um inventário composto por 21 itens de múltipla escolha, utilizado para avaliar o grau da ansiedade de um indivíduo, com alternativas de respostas variando de nada a um pouco, moderadamente e gravemente. O BAI tem sido recorrentemente utilizado para medir por meio do autorrelato do cliente a severidade da ansiedade. Beck, Epstein, Brown e Steer (1988) ainda sugerem que o BAI também pode ser utilizado como uma medida de resultado da terapia (Anexo 4).

\section{Procedimento}

\section{1) Seleção dos participantes}

Nesta etapa o pesquisador-terapeuta e a orientadora-supervisora selecionaram uma cliente. Esta seleção foi realizada por meio da leitura das fichas que da triagem da clínicaescola de um instituto de formação de terapeutas analítico-comportamentais. A cliente selecionada (tal como indicado nas características do cliente) foi contatada pelo pesquisador e questionada sobre o interesse em receber atendimento e sobre a participação na pesquisa.

\section{2) Unidades de medida}

Nos estudos de categorias comportamentais, como sustenta Zamignani (2007), há certo debate sobre quais medidas poderiam ser utilizadas para descrevê-las. De um modo geral, esse autor aponta que, tradicionalmente, por conta da pesquisa básica e experimental, a 
análise do comportamento apresentava costumeiramente seus resultados em frequência de respostas, e esta se mostrou uma medida bastante apropriada para representar o processo de aquisição de comportamentos. Contudo, em estudos de categorias de comportamento, recorrer a "utilização da freqüência como dimensão representativa da ocorrência de determinadas categorias de comportamento coloca em um mesmo nível de análise (e, portanto, as considera comparáveis) desde verbalizações mínimas (...) até longo segmentos de verbalização” (p.27). Sendo assim, pode-se superestimar verbalizações mínimas na terapia.

Para Sturmey (1996), em muitos comportamentos clinicamente importantes a duração e a proporção do tempo em que estes se estendem são medidas muito mais importantes que a frequência deste. Assim, na clínica, seria mais interessante recorrer à duração das categorias de comportamento como medida representativa dessas que, por exemplo, a frequência.

Por outro lado, para Sturmey (1996) e Zamignani (2007), a adoção exclusiva da medida duração subestima a importância de comportamentos com duração mínima na clínica que seriam superestimados com a freqüência. Ambos os autores sugerem então a adoção de ambas.

Logo, pautado nesses argumentos, esse estudo irá conciliar ambas as medidas, duração e freqüência, como medidas representativas das categorias de comportamentos.

\section{3) Procedimento experimental}

Esse estudo se valeu do entrecruzamento de duas metodologias de pesquisa clínica, encabeçadas pelas pesquisas de resultado e de processo. Por um lado, foram comparados os resultados do Inventário de Ansiedade do Beck (BAI) e da Escala de Avaliação de Sintomas (EAS-40), que foram aplicados no início de cada fase. Por outro, através da observação, buscou-se a identificação de regularidades e padrões de interação permitidas pelo SiMCITT. 
A intervenção terapêutica consistiu em 21 sessões, com a duração de 50 minutos cada. Foi utilizado o delineamento de caso único, do tipo A-B-A-B, no qual o participante foi o próprio controle das medidas observadas e dessa forma sua história de vida e as variáveis relativas aos diferentes contextos em que estava inserido foram consideradas. Neste, uma variável é selecionada (VI), e, ao ser introduzida em alguns momentos, seus efeitos são observados (VDs), comparando-os com a linha de base, a situação em que tal variável não estava presente. Vale ressaltar que, dentre as características deste tipo de delineamento, seu formato permite realizar sucessivas comparações entre condições controle e condições experimentais em um mesmo caso. Assim, os resultados podem indicar se de fato foi a VI responsável pela modificação na VD, caso, por exemplo, se o desempenho da VD se modificar quando a VI for inserida (B), voltar à condição anterior a tal inserção quando a VI for retirada (A), e mudar novamente quando a VI for reinserida (B) (Kazdin, 1982).

A variável independente desta pesquisa foram metáforas orientadas para valores da Terapia de Aceitação e Compromisso, ou, ACT (da sigla em inglês Acceptance and Commitment Therapy). Essas metáforas foram extraídas e compiladas de manuais e livros da Terapia de Aceitação e Compromisso (Eifert \& Forsyth, 2005; Hayes et al. 1999; Luoma et al. 2007; Wilson \& Luciano, 2002) e do portal da ACBS (da sigla em inglês Association for Contextual and Behavioral Science), localizado no sítio: http://contextualscience.org/acbs.

A estrutura do delineamento desta pesquisa pode ser apresentada da seguinte maneira:

\section{Linha de Base + TAC, TACM, TAC e TACM.}

Considerando a complexidade do fenômeno comportamental na clínica - o grau de variabilidade intra-sujeito dos clientes - as fases foram encerradas a partir do momento em que se alcançou uma formulação bem definida do caso e uma variação máxima de $20 \%$ da frequência relativa entre as ocorrências da categoria CER por três sessões, ou, uma variação máxima de $10 \%$ em relação à ocorrência total da CER na sessão, por três sessões. 
Dada a possibilidade de influências de variáveis estranhas e difíceis de serem controladas no ambiente clínico, foi permitido "descartar" uma sessão para admitir-se a estabilidade dos dados e a mudança de fase, contanto que não fosse a última sessão da fase.

Caso os critérios de estabilidade de tal VD não fossem atingidos até a oitava sessão, a próxima fase seria iniciada a despeito disso. Neste caso, as comparações de estabilidade das próximas fases poderiam ser feitas com um possível padrão de variação de CER observado nessa fase inicial.

Como critério último para mudanças de fases foi utilizada como um norteador a inspeção visual dos dados, especialmente da VD CER. Dessa maneira, uma nova fase só era iniciada se a VD CER não apresentasse grandes variações em sua ocorrência, ou, tendências comportamentais, como um aumento e/ou diminuição constantes e recorrentes entre as sessões. A figura no capítulo 5 "Resultados e discussão" apresenta as porcentagens da ocorrência da categoria CER por sessão. No início de cada fase e na última sessão do procedimento eram aplicadas a Escala de Avaliação de Sintomas (EAS 40) e o Inventário de Ansiedade de Beck (BAI).

\section{1) Fase A1: Linha de Base e Terapia Analítico-Comportamental}

Nesta fase foi priorizado (1) o estabelecimento de vínculo, aumentando a adesão à terapia/pesquisa e diminuindo a chance de uma possível desistência, e (2) a coleta de informações iniciais. Além disso, foi realizada a conceituação do caso e a mensuração das VDs, a categoria CER pelo SiMCITT, até se obter dados relativamente estáveis.

Vale ressaltar que o manejo de metáforas nessa fase, assim como na fase A2, era preterido, se não inexistente, pelo terapeuta. Este não apresentava nenhuma metáfora 
orientada para valores, tampouco aprofundava ou explorava alguma metáfora que a cliente pudesse apresentar nas sessões.

Por se tratar da linha de base, considerou-se ampliar esta fase, e estendê-la por sete sessões.

\section{2) Fase B1: TACM (Terapia analítico-comportamental e metáforas)}

Nesse período, o pesquisador-terapeuta realizou intervenções de análise de contingências dos relatos do cliente e, no que tange às consequências das ações do cliente, foi priorizado o manejo de metáforas e uso de metáforas pré-estabelecidas orientadas para os valores do cliente (Anexo 5).

A escolha do momento na sessão e da metáfora que seria utilizada ficou a cargo do pesquisador-terapeuta, dada a conceituação e o desenrolar do caso, a análise de contingências em vigor neste (e o efeito cumulativo destas no repertório do cliente), as idiossincrasias do cliente, o tema da sessão e o tema da metáfora, e, a experiência clínica e julgamento do terapeuta para considerar proveitoso o manejo de metáforas orientadas para valores naquela ocasião, considerando a responsividade defendida por Stiles (1999), como é discutido na figura 7 do próximo capítulo "Resultados e discussão". Dessa maneira, em geral, as metáforas eram apresentadas ao final de cada sessão.

.Nesta fase, foram apresentadas as primeiras quatro metáforas contidas no Anexo 5, uma em cada sessão. Na medida em que eram consideradas úteis, e o cliente as recuperava, o terapeuta as abordava livremente, independentemente da sessão e da metáfora, como ocorreu na sessão 10, em que a cliente fez uma comparação entre as metáforas 1 e 3. 
Vale ressaltar que outras intervenções não-programadas poderiam ser utilizadas por se tratar de um processo terapêutico.

Essa fase e as demais se estenderam até que fosse atingido o critério de estabilidade, durante três sessões, com a possibilidade de ser descartada uma das sessões para a troca de fases, contanto que não fosse a última. Ela durou quatro sessões.

\section{3) Fase A2: Terapia analítico-comportamental (TAC)}

Nessa fase, o pesquisador-terapeuta realizou intervenções de análise de contingências dos relatos do cliente e, no que tange os valores e as consequiências de respostas do cliente, o uso de intervenções metafóricas foi preterido em relação a outras possíveis intervenções do terapeuta, como confrontações, informações, e até recomendações para a ação, tal como descrito na fase A1. Caso a cliente remetesse a alguma das metáforas previamente utilizadas na fase B1, ou, relatasse eventos por meio de metáforas novas, o terapeuta estava instruído a pouco explorá-las ou pedir dados sobre possíveis eventos concretos correspondentes ao relato metafórico.

Conforme mencionado anteriormente, essa fase e as demais se estenderam até que fosse atingido o critério de estabilidade, durante três sessões, com a possibilidade de ser descartada uma das sessões para a troca de fases, contanto que não fosse a última. Ela durou cinco sessões.

\section{4) Fase B2: TACM (Terapia analítico-comportamental e metáforas)}

Nessa fase, o pesquisador-terapeuta realizou intervenções de análise de contingências dos relatos do cliente e novamente, em relação às consequências das ações do cliente, foi 
priorizado o manejo e a inserção de metáforas orientadas aos valores do cliente, tal como descrito na fase B1. Foram utilizadas duas metáforas novas, não apresentadas até então na terapia, a $5^{\mathrm{a}}$ na sessão 17 , e a $6^{\mathrm{a}}$ na sessão 20.

Esta fase durou cinco sessões. Contudo, por conta das férias programadas da cliente e a opção (metodológica) por manutenção do número das sessões desta fase, o período de tempo entre as sessões foi encurtado. Duas delas tiveram apenas dois dias de diferença.

\section{4) Análise dos dados}

Após coletados, os dados foram analisados mediante uma planilha de Excel desenvolvida especificamente para a análise de resultados de pesquisas que se valeram do SiMCITT para a categorização de dados.

Nessa etapa foi feito um esforço de convergência e ordenamento das possíveis correlações e causações visualizadas nestes dados, entre os comportamentos do terapeuta e do cliente, sobretudo nos episódios em que ocorreram os manejos de metáforas, como análises sequenciais, a probabilidade condicional de ocorrência de uma dada categoria após outra, e etc.

Além disso, foram analisados os dados obtidos com a categorização das sessões, com a avaliação da qualidade das relações estabelecidas pelo cliente, e os resultados do EAS-40 e do BAI.

\section{Concordância entre observadores}

A concordância entre observadores foi realizada pelo cálculo do índice Kappa, que leva em conta a proporção da concordância observada e proporção da concordância ao acaso 
(Suen \& Ary, 1989). Assim, uma sessão foi categorizada pelo categorizador e pelo aferidor de concordância, e teve seu índice kappa medido. Para a categorização do terapeuta, o índice kappa fora 0,88 , e para o cliente 0,73 .

Segundo Kazdin (1982), a concordância entre observadores é de bastante importância para pesquisas aplicadas pois assegura a consistência entre observadores, diminui possíveis efeitos de vieses de observação e indica uma boa operacionalização dos comportamentos de interesse.

\section{ASPECTOS ÉTICOS}

O presente estudo foi conduzido com os devidos cuidados éticos, nos termos da Resolução 466/2012, do Conselho Nacional de Saúde. A pesquisa foi iniciada, somente, após ter sido submetida à apreciação e aprovada no dia 13 de maio de 2013 por uma Comissão de Ética em Pesquisas com Seres Humanos, por meio da Plataforma Brasil, pelo site: http://aplicacao.saude.gov.br/plataformabrasil/login.jsf, mediante o parecer consubstanciado número 270.743. Foi solicitado a cliente que assinasse o Termo de Consentimento Livre e Esclarecido (Anexo 1), autorizando a utilização dos dados obtidos. O categorizador assinou o Termo de Responsabilidade. Quanto à publicação e/ou apresentação dos resultados da pesquisa, os dados de identificação da cliente não foram, nem serão, divulgados, considerando o devido cuidado para o sigilo. Para garantir tal sigilo houve alteração dos dados que de alguma forma poderiam identificar o cliente e a ocultação de dados desnecessários para os diversos meios de divulgação científica. Além disso, após a utilização dos dados coletados para a presente pesquisa, as mídias contendo as gravações das sessões dos clientes foram guardadas em local seguro pertencente ao Laboratório de Terapia Comportamental da 
Universidade de São Paulo. A cliente foi informada disso e a destruição das mídias poderia ser solicitada pela cliente sem que nenhum prejuízo esteja implicado para este.

O pesquisador foi responsável pelo andamento da pesquisa, pela aplicação dos procedimentos e avaliação do bem-estar da cliente durante o andamento da coleta de dados. Caso na época da coleta fosse identificado qualquer problema e/ou desconforto da cliente, o pesquisador-terapeuta conversaria com o cliente e, se fosse o caso, ela teria a liberdade de interromper o tratamento. A interrupção da pesquisa também poderia ser solicitada a qualquer momento pela cliente, sendo que seu direito a atendimento continuaria garantido. Caso a cliente solicitasse a não-inclusão dos dados na presente pesquisa o direito de atendimento seria garantido e, novamente, nenhum prejuízo estaria implicado para este. O próprio pesquisador-terapeuta garantiria um encaminhamento do cliente para outro terapeuta ao menos igualmente qualificado.

O atendimento foi supervisionado pela orientadora do Programa de Pós-graduação em Psicologia Clínica do IPUSP, no grupo de supervisão do Laboratório de Terapia Comportamental. 


\section{RESULTADOS E DISCUSSÃO}

Os dados apresentados a seguir foram obtidos a partir da análise de 21 sessões de psicoterapia analítico-comportamental com a cliente. Foram no total 17 horas, 31 minutos e 51 segundos de gravações transformados em 3715 unidades de análise, ocorrências de categorias, de acordo com o SiMCCIT, o Sistema Multidimensional de Categorização de Comportamentos na Interação Terapêutica, cinco folhas de registro do Inventário de Ansiedade de Beck, BAI, e cinco da Escala de Avaliação de Sintomas - EAS 40.

Destes, 2 horas, 24 minutos e oito segundos e 2629 foram a duração e ocorrências de categorias nas falas do terapeuta, respectivamente, assim como 14 horas, 26 minutos e 2 segundos e 1087 foram da cliente. O tempo restante é a diferença entre o início e término das gravações e o início e término das sessões. Eventuais silêncios e pausas nas sessões foram incluídos nas análises, como prevê o manual do SiMCCIT (Zamignani, 2007).

Os resultados estão dispostos da seguinte maneira: (1) Dados do Sistema Multidimensional de Categorização de Comportamentos na Interação Terapêutica; (2) dados obtidos de acordo com as fases do delineamento experimental; (3) Caracterização de um episódio de manejo de metáfora; e (4) dados obtidos das medidas de resultado, o BAI e o EAS 40.

De um modo geral, cabe ressaltar que a cliente do estudo, Natália, fora encaminhada para terapia analítico-comportamental após um episódio que essa relata como "crise de ansiedade" (SIC), em que parou em uma cadeira de rodas em um hospital. Na ocasião, Natália fora diagnosticada com transtorno de ansiedade generalizada.

No início da terapia ela tinha 37 anos, namorava há dois, e trabalhava como gerente operacional de uma empresa de gestão contábil. Boa parte das sessões aqui analisadas tinham 
como tema o ambiente de trabalho, as demandas deste, e como entravam em conflito valores da cliente de "ser justa" e com assertividade, seja no trabalho com os seus chefes, em casa com a irmã, ou com o namorado no relacionamento amoroso.

Também foi foco de intervenções o repertório de tomada de decisões de Natália e de resolução de conflitos.

\section{Dados do Sistema Multidimensional de Categorização de Comportamentos na}

\section{Interação Terapêutica.}

A Figura 1 a seguir apresenta a distribuição das porcentagens relativas às ocorrências e durações das categorias no sistema SiMCCIT ao longo das 21 sessões da cliente Natália.

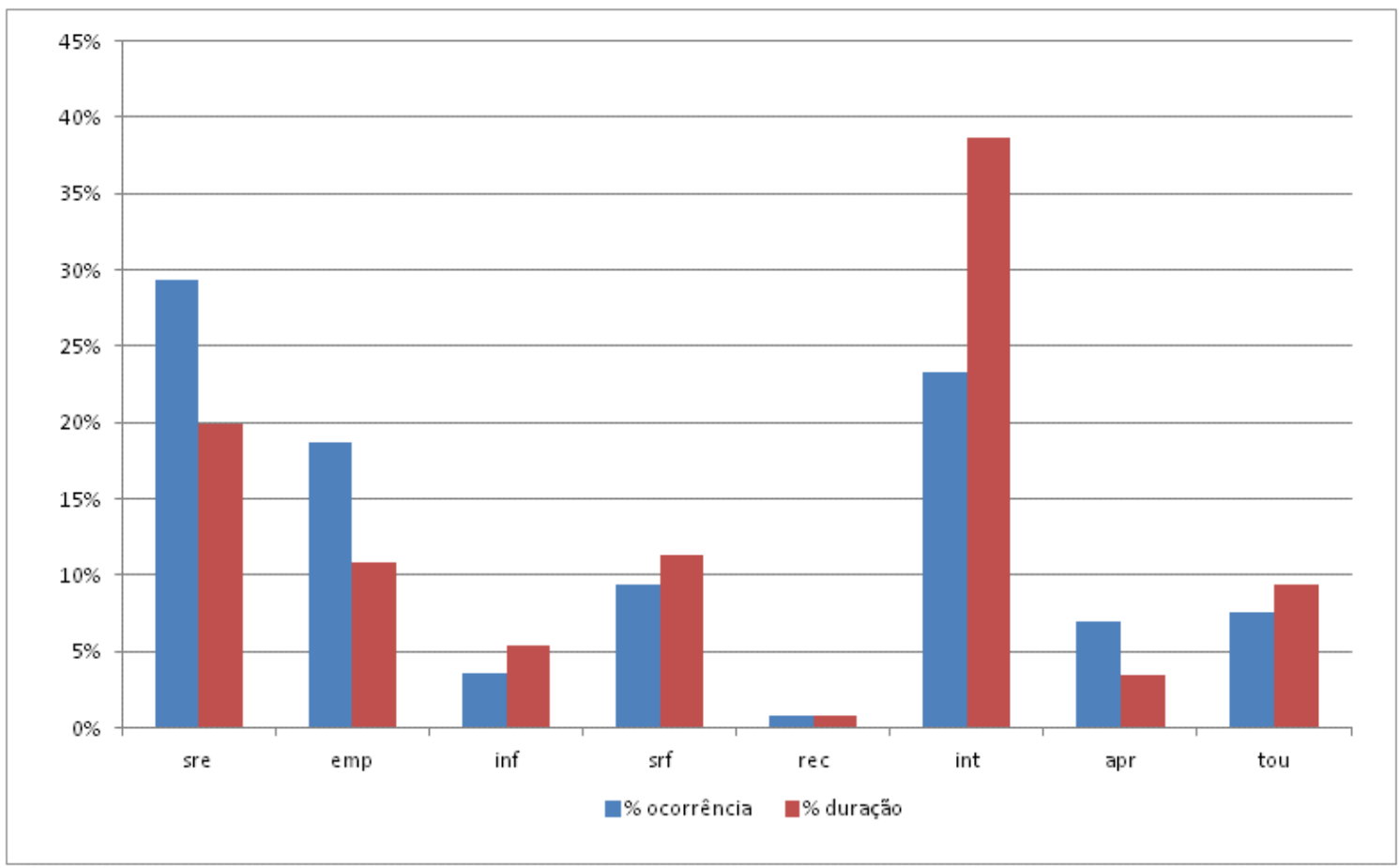

Figura 1. Frequência e duração relativas às categorias do terapeuta pelo SiMCCIT nas 21 sessões de psicoterapia. 
As categorias mais recorrentes foram interpretação e solicitação de relato, que alternaram entre si, a depender da medida de análise utilizada. Na ocorrência, solicitação de relato (SRE) aparece com maior frequência, 29,39\%, enquanto que interpretação (INT) teve $23,32 \%$. Por outro lado, inversamente, em termos de duração, interpretação se destaca com $38,72 \%$, enquanto que solicitação de relato com $19,9 \%$.

Evidencia-se também a empatia (categoria EMP, no gráfico), com $18,74 \%$ relativa à ocorrência e 10,78\% à duração, e a solicitação de reflexão (SRF), com 9,37\% relativo à ocorrência e $11,37 \%$ à duração.

Foram retirados dos gráficos do terapeuta os dados referentes às categorias facilitação (FAC), terapeuta permanece em silêncio (TSL) e reprovação (REP) por motivos diversos. Facilitação por conta de, caso tivessem sido incluídos, seja no gráfico ou no cálculo das porcentagens, obscureceriam os demais dados. Foi registrado um total de 1690 facilitações durante a coleta da pesquisa. Por outro lado, terapeuta permanece em silêncio e reprovação foram excluídos por serem considerados irrisórios, embora estes ainda estejam inclusos no cálculo das porcentagens. Terapeuta permanece em silêncio só foi registrado uma única vez, com uma duração de 10 segundos, ao passo que não houve falas categorizadas como reprovação.

Há de se assinalar também o número relativamente alto de falas registradas como TOU, outras vocal terapeuta, por conta do acerto de contrato, dadas as especificidades de uma pesquisa clínica, eventuais dúvidas e preenchimentos das folhas de registro referentes às medidas de resultado utilizadas, o Inventário de Ansiedade de Beck (BAI) e a Escala de Avaliação de Sintomas (EAS-40). 
De modo geral, pode-se analisar o padrão de responder do terapeuta como empático e reflexivo, possivelmente confrontativo, dado o número consideravelmente alto de interpretações (caberia analisar separadamente as subcategorias dessa para se precisar exatamente o quão confrontativo o terapeuta foi), assim como pouco recomendativo. Recomendações só foram registradas 8 vezes, num total de 1 minuto e 9 segundos de duração.

Um dado interessante notado por Zamignani (2007) foi que categorias interpretação e solicitação de reflexão seriam responsáveis por mudanças comportamentais ao longo do processo terapêutico, juntamente às categorias recomendação e aprovação. Logo, talvez esses altos dígitos de INT e SRF, somados aos de EMP, possam ser entendidos como descritores de um bom processo terapêutico por parte do terapeuta, quem sabe, eficaz e cuidadoso.

Os dados a seguir, dispostos na Figura 2, mostram a frequência e a duração das categorias da cliente obtidas nas 21 sessões de psicoterapia.

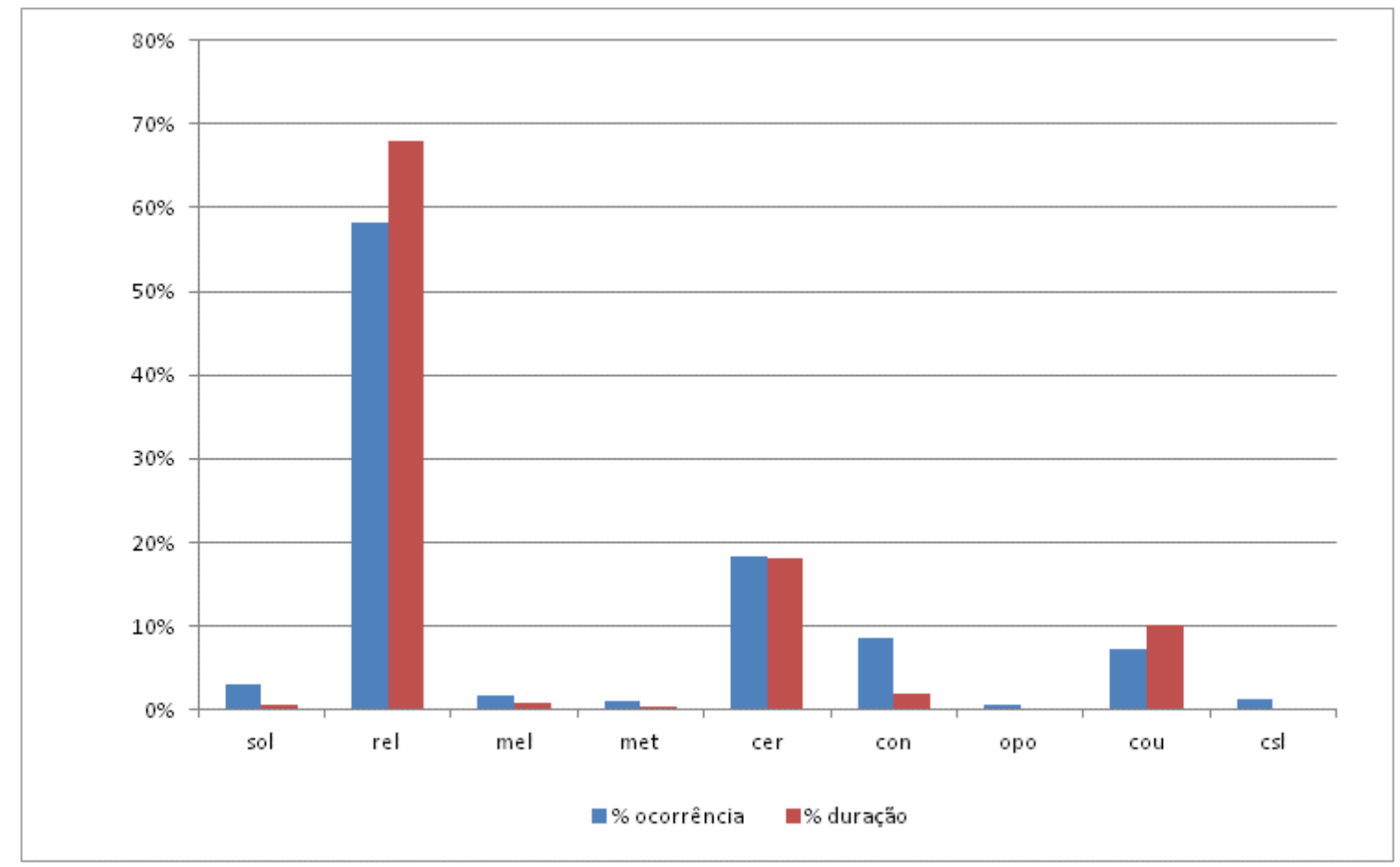

Figura 2. Frequência e duração relativas às categorias da cliente Natália no SiMCCIT nas 21 sessões de psicoterapia. 
Na Figura 2 observa-se que as categorias mais presentes nas sessões foram relato (REL) e cliente estabelece relações (CER), independentemente da medida de análise utilizada. REL ocorreu $58,14 \%$ e durou $68,04 \%$ do total das sessões, enquanto que CER $18,31 \%$ e $18,01 \%$ respectivamente.

Novamente, assinala-se a ocorrência e duração relativamente alta da categoria outras vocal cliente (COU), 7,18\% e 10,04\%, devido aos acertos e reasseguramentos do contrato da terapia e da pesquisa ao longo dessas, assim como o responder as folhas de registro do BAI e EAS-40, tal qual para o terapeuta, como descrito anteriormente.

Talvez os diferentes índices de concordância, 8,56\% de ocorrência e 1,94\% de duração, ao serem comparados aos quase inexistentes de oposição, 0,64\% de ocorrência e 0,10\% de duração, possam ser indicativos de uma boa relação terapêutica, ou, mais especificamente, de uma aliança terapêutica de qualidade.

Para Kohlenberg e Tsai (2001), a aliança terapêutica seria um componente vital da relação terapêutica, e remeteria à habilidade do cliente em se auto-observar no contexto de terapia.Também facilitaria a ocorrência de outros comportamentos de melhora na terapia (comportamentos clinicamente relevantes).

Alguns autores, como Horvath e Symonds (1991), em uma metanálise com 24 estudos que cruzam dados da qualidade da aliança terapêutica com desfechos da terapia, concluem que a qualidade da aliança terapêutica seria, no mínimo, um dos fatores preditivos de desfechos positivos de tratamentos.

Assim, aos se confrontar os dados da CON e OPO com REL e CER, pode-se supor que a terapia foi minimamente evocativa, e que talvez a cliente tenha se sentido confortável para expor-se e posicionar-se diante do terapeuta, e além de refletir sobre o conteúdo exposto. 
Paralelamente, os números baixos da ocorrência $(3,04 \%)$ e duração $(0,55 \%)$ da categoria solicitação (SOL) podem sugerir que, ao menos diretamente, a cliente pouco demandou do terapeuta nas sessões.

A Figura 3 adiante apresenta as porcentagens relativas à ocorrência das categorias do terapeuta difundidas por cada uma das 21 sessões.

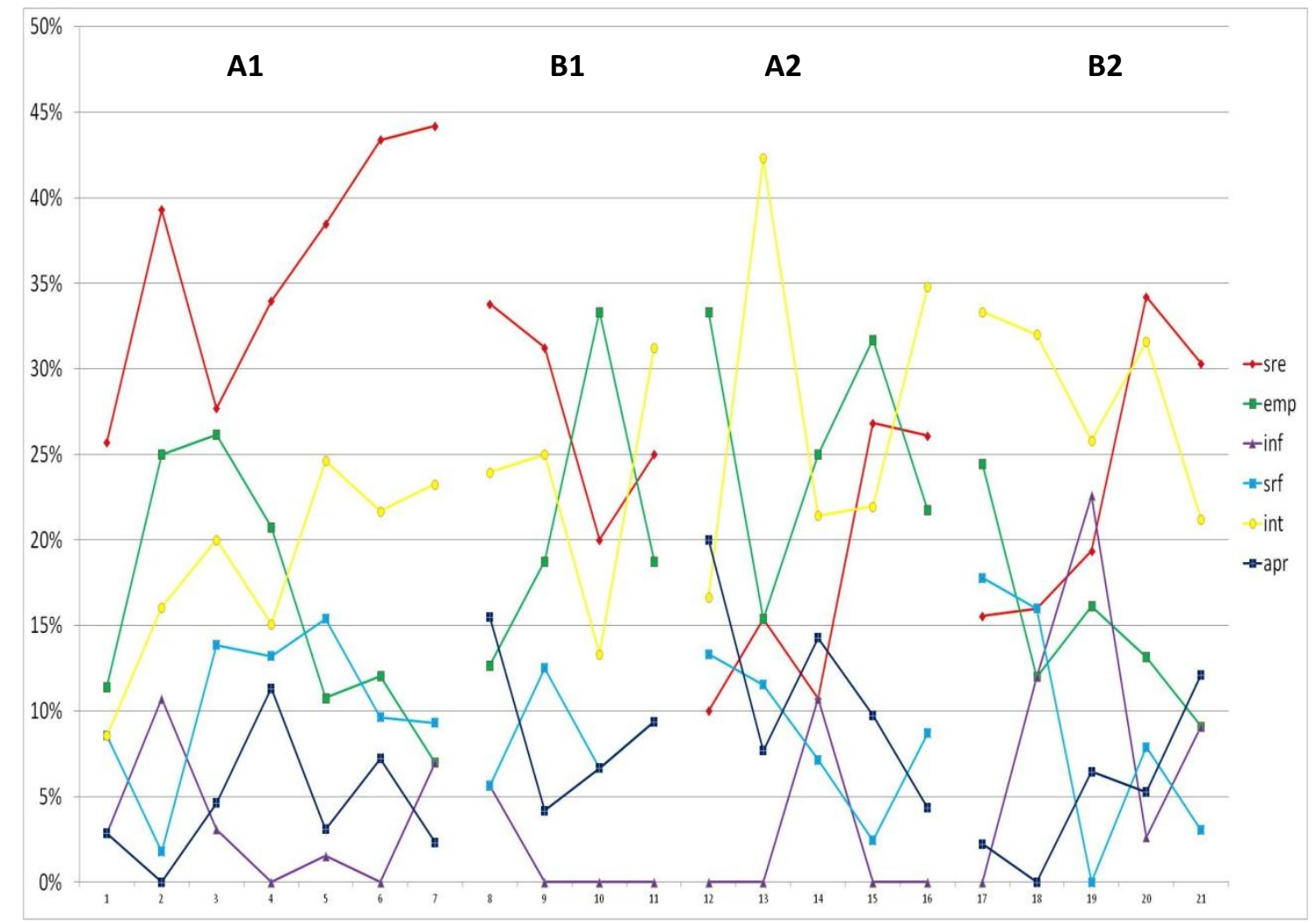

Figura 3. Porcentagens de ocorrência das categorias do terapeuta distribuídos em cada sessão.

A distribuição da ocorrência das categorias do terapeuta por sessão, em geral, evidencia as flutuações do padrão de responder dele durante o processo de tomada de decisões enquanto clínico e pesquisador. Neste processo, caberia ressaltar possíveis variáveis controlando o comportamento do terapeuta, como (1) a formação deste, a história profissional e pessoal, supervisão, e o modo como devem articular-se de maneira passiva e ativa (2) variáveis como evidências científicas (dados de pesquisas clínicas, básicas, aplicadas, 
documentais, entre outras), variáveis dessa cliente específica, Natália, e, neste caso, variáveis do procedimento experimental, como as diferenças entre as fases previstas no método (APA, 2006).

Quanto às porcentagens da ocorrência, salta aos olhos a categoria solicitação de relato (SRE), com um valor máximo de 44,19\% na sessão $710 \%$ na sessão 12 . Outras categorias de destaque foram interpretação (INT), com um valor máximo de 42,13\% na sessão 13 e 8,57\% na sessão 1 e 13,33\% na sessão 10, e empatia (EMP), com valor máximo de 33,33\% nas sessões 10 e 12 e mínimo de 4,29\%. Solicitação de reflexão (SRF), por sua vez, teve de $17,78 \%$ na sessão 17 e não ocorre na sessão 19.

A Figura 4 a seguir detalha as porcentagens de duração referente às categorias do terapeuta por sessão.

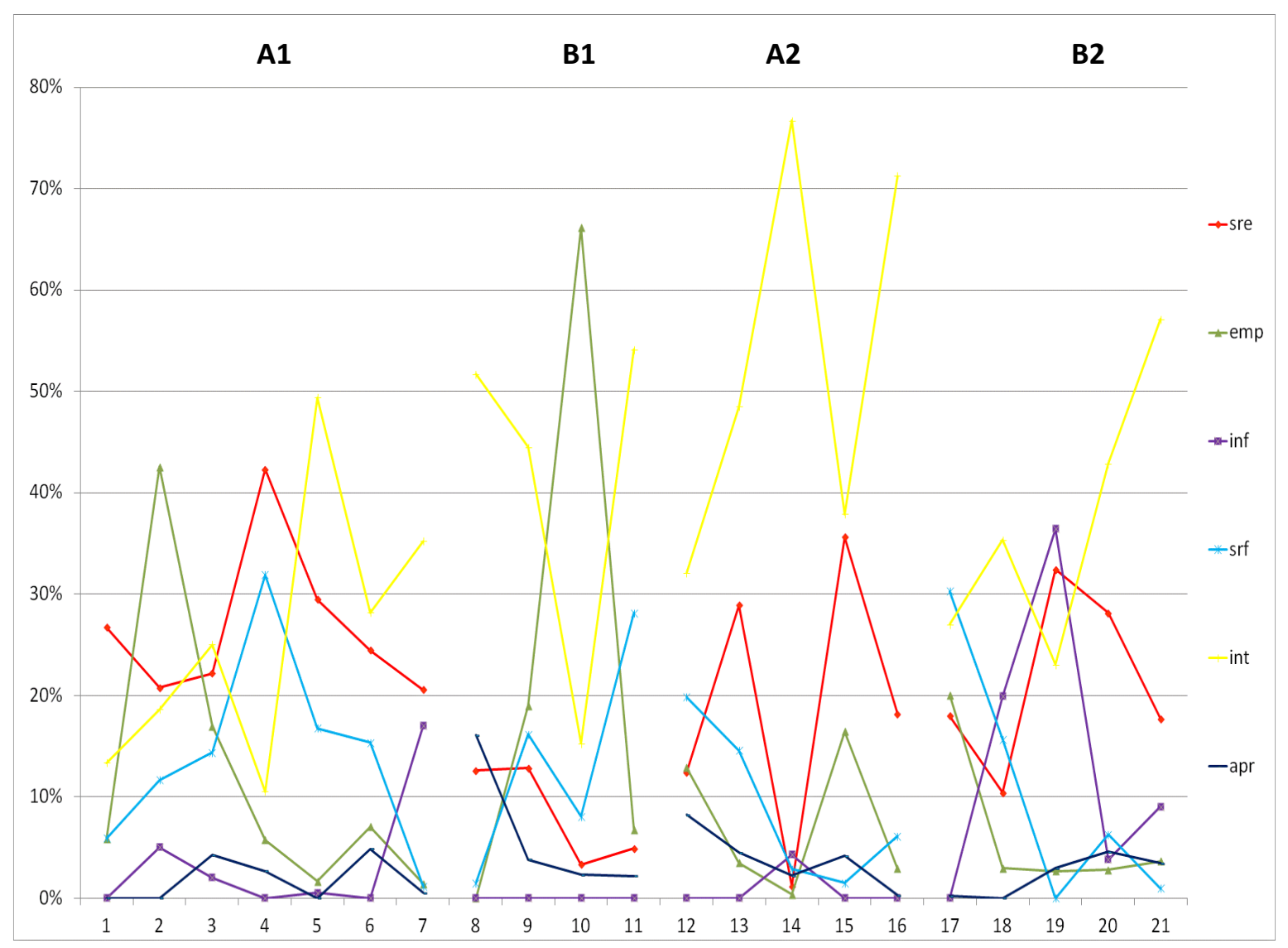

Figura 4. Porcentagens de duração das categorias do terapeuta distribuídos por sessão. 
As porcentagens de duração das categorias do terapeuta por sessão ressaltam, tal qual na ocorrência (Figura 3), as mudanças em seu padrão de responder durante o processo de tomada de decisões enquanto clínico e pesquisador.

Interpretação e empatia novamente são destaques. INT com valor máximo de 76,7 \% na sessão 14 e mínimo de 10,54\% na sessão 4, e EMP com máximo de 66,15\% na sessão 10 e mínimo de 0,36\% na sessão 14 .

Enquanto que solicitação de relato (SRE), alcançou 42,3\% na sessão 4 e mínimo de $1,18 \%$ na sessão 14 , e solicitação de reflexão (SRF) obteve $31,9 \%$ também na sessão 4 e não ocorreu na sessão 19.

A Figura 5 adiante apresenta as porcentagens da ocorrência das categorias do cliente.

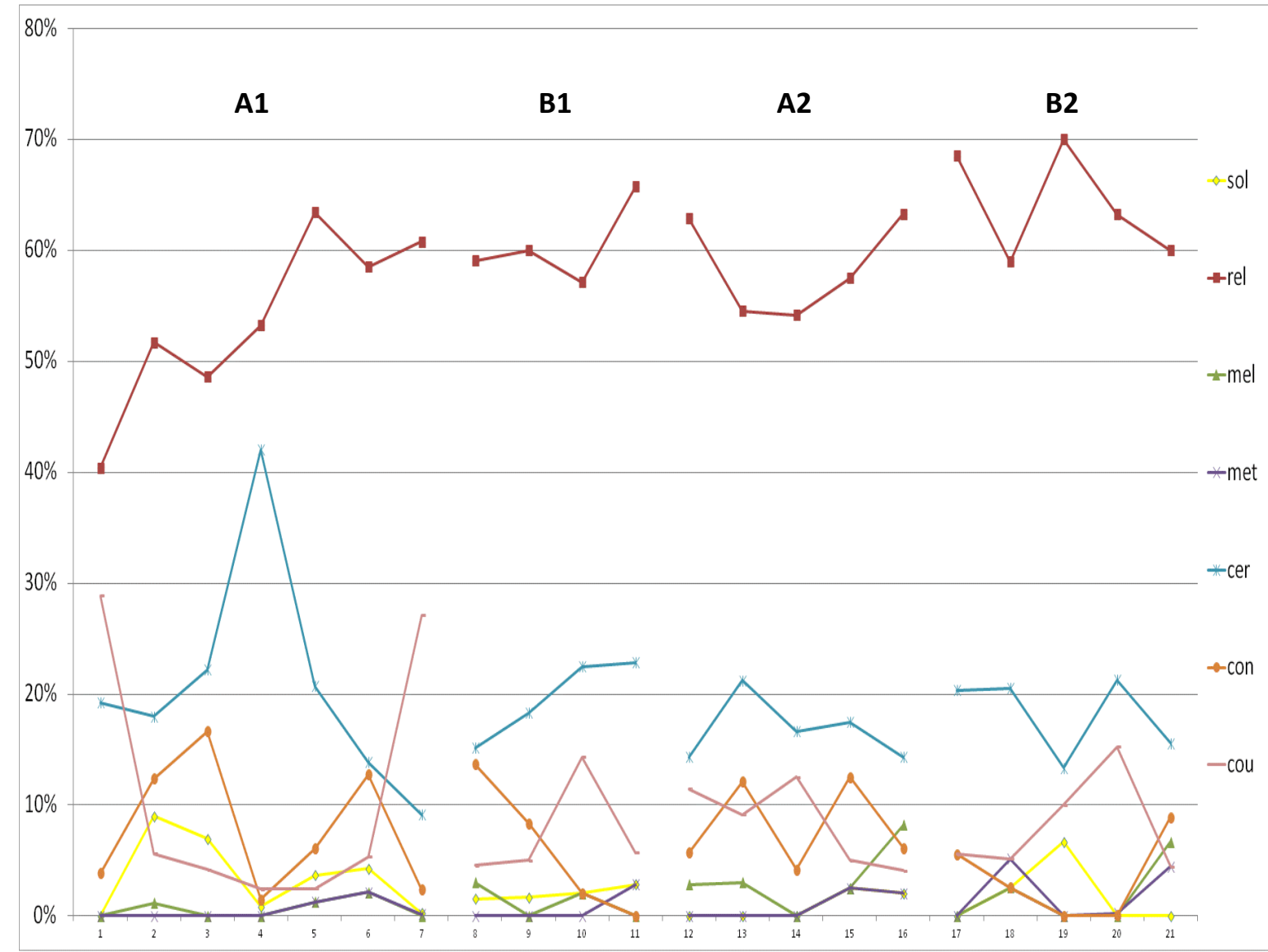

Figura 5. Porcentagens da ocorrência das categorias do cliente distribuídos por sessão. 
As porcentagens de ocorrência das categorias do cliente por sessão, por sua vez, apresentam o padrão de responder do cliente na sessão, em ambiente terapêutico. É visível a diferença da categoria relato (REL), a categoria com maior ocorrência em todas as sessões, com valores máximo de $70 \%$ na sessão 19 e mínimo de 40,48\% na primeira sessão. Outra categoria relevante é a cliente estabelece relações (CER), com valores entre máximo de 42,02\% na sessão 4 e mínimo de $9,15 \%$ na sessão 7 .

A Figura 6 a seguir detalha as porcentagens da duração das categorias do cliente por sessão.

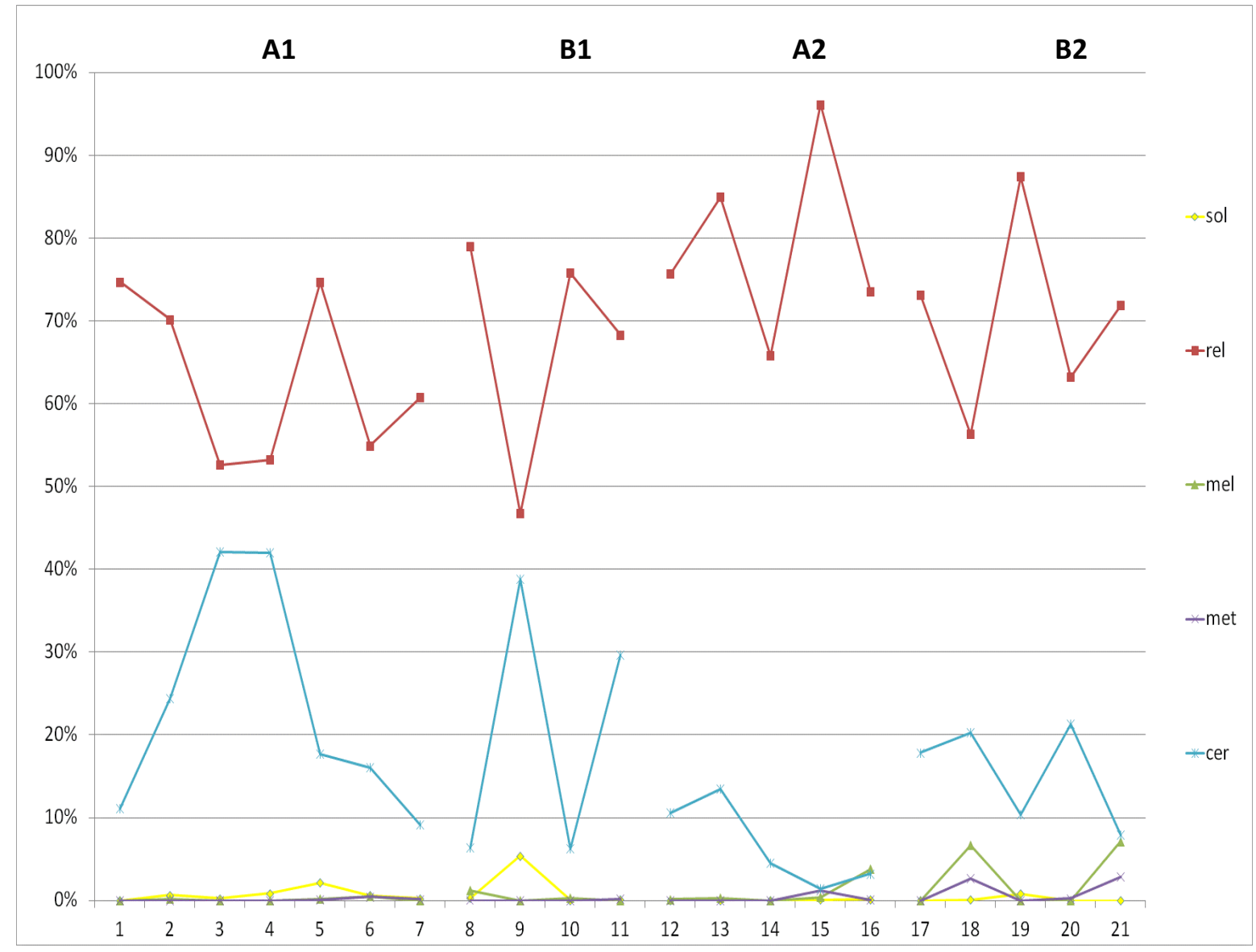

Figura 6. Porcentagens da duração das categorias do cliente distribuídos por sessão.

As porcentagens de duração das categorias do cliente por sessão, novamente, destacam o padrão de responder da cliente nesta. Nota-se, novamente, a predominância da categoria relato, com valor máximo de $96,13 \%$ na sessão 15 e mínimo de 46,75\% na sessão 9 . 
Há que se ponderar também possíveis comparações entre a sessão 1 e as demais sessões pois a gravação dessa tem apenas $31: 41$ s. O terapeuta iniciou a gravação somente após o consentimento da cliente, mediante acordo verbal e o preenchimento do Termo de consentimento livre e esclarecido para clientes na sessão (Anexo 1).

Confrontando os dados das quatro figuras, $3,4,5$ e 6 , em uma primeira inspeção visual, é possível observar certa correspondência entre as categorias SRF e CER, como mostra figura 7 a seguir.

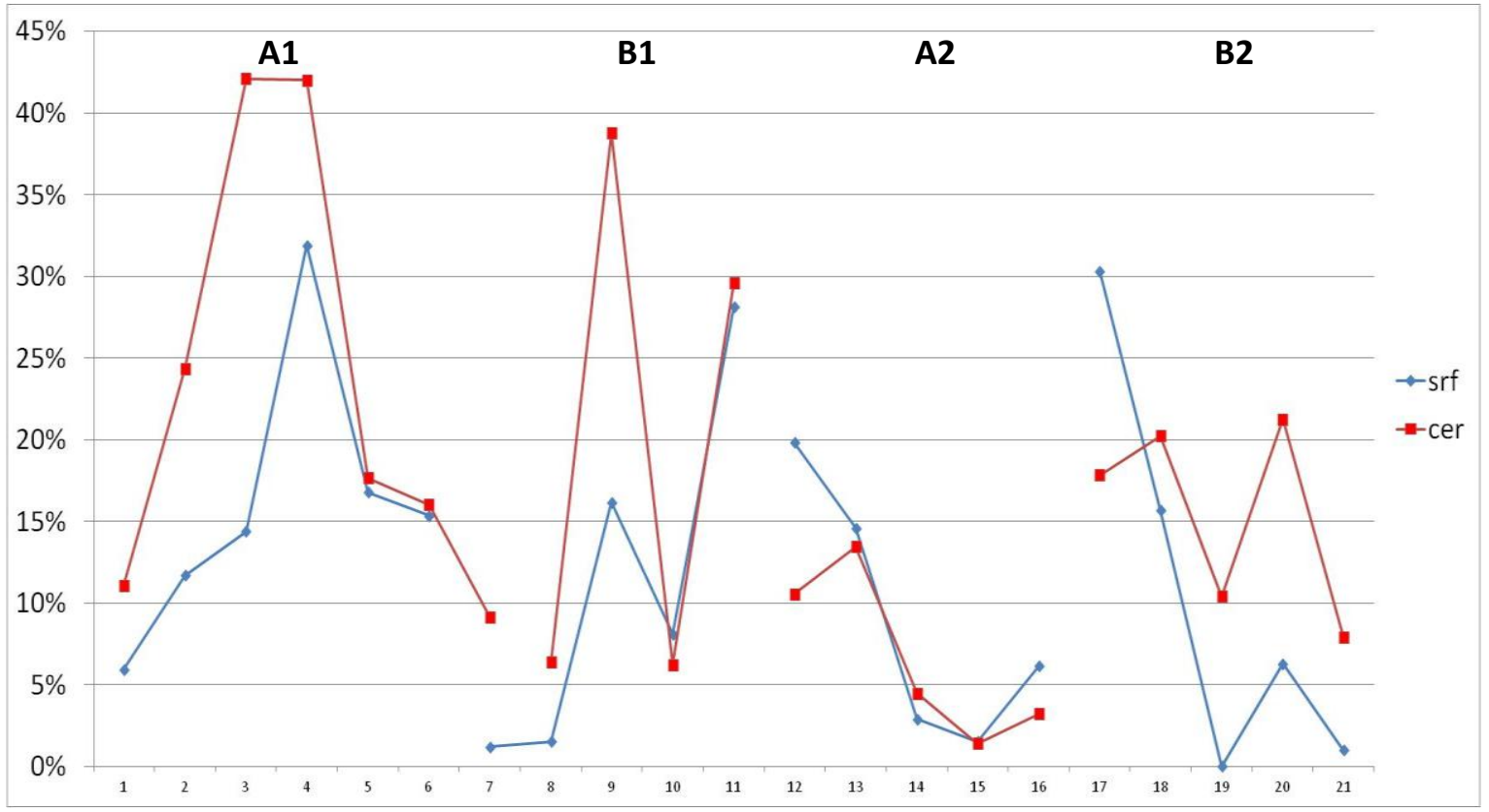

Figura 7. Porcentagens de duração das categorias solicitação de reflexão do terapeuta e cliente estabelece de relações.

Tal correlação pode ser produto de não somente "boas" SRF, mas também de o terapeuta estar sensível a que momento instigar a cliente na sessão, em que ocasião solicitar e 
promover reflexões à cliente, de acordo com o material apresentado pelo cliente. Ou seja, que o terapeuta tenha sido responsivo.

Stiles (1999) considera responsividade como o terapeuta responder de acordo com o contexto emergente na sessão, de um modo que avance os objetivos estabelecidos na terapia. Basicamente, considerar as variáveis do cliente e da relação terapêutica ao intervir. Este autor ressalta que intervenções, mesmo baseadas em evidências, ao serem aplicadas em clientes com problemas semelhantes ao de uma pesquisa em que essa intervenção originou resultados positivos, podem produzir resultados negativos, pelo fato do terapeuta não ter sido responsivo.

Tal correlação bastante próxima é visível até a sessão 19. A sessão 19 é um caso à parte. A cliente Natália chegou por volta de 30 minutos atrasada e, ao longo da sessão, aparentou estar bastante cansada. Estava com uma viagem marcada e queixou-se de ter contraído uma infecção urinária e estar "meio crica” (SIC), dias antes do embarque. Após interações ligadas à preocupação do terapeuta com a cliente e respostas dessa sobre sua condição de saúde, Natália pôs-se a refletir como sua saúde teria "recaídas danadas" (SIC) por conta de períodos de grandes exigências no ambiente de trabalho.

De todo modo, por conta do tempo reduzido da sessão, das condições de saúde da cliente, de já estarem ocorrendo relações, e a pedido expresso da cliente, o terapeuta não manejou metáforas nesta sessão. Ou seja, este não apresentou nenhuma metáfora nova, nem se referiu a qualquer metáfora previamente utilizada ao se dirigir a cliente, embora esta fosse uma sessão experimental, parte da fase B2. Até fora aberto à Natália a possibilidade de estenderem a sessão, mas esta pediu para "deixar para a próxima” (SIC).

Contudo, tanto na sessão 19 como nas demais (20 e 21) houve um número considerável de estabelecimento de relações em comparação com às sessões anteriores. É 
possível supor que, por conta de intervenções realizadas previamente na terapia, em outras sessões, possivelmente interpretações e solicitações de reflexão pelo terapeuta, outras intervenções (como a solicitação de relato e empatia, de acordo com o SiMCCIT) assumiram a função de promover reflexão. Ou seja, evocaram o estabelecimento de relações por parte da cliente. Talvez um possível desdobramento do efeito pervasivo do comportamento verbal no contexto da terapia.

Mais comparações sobre as mudanças entre as fases do procedimento experimental, sobretudo na categoria estabelecimento de relações, serão apresentadas no tópico a seguir.

\section{Dados obtidos de acordo com as fases do delineamento experimental}

Como em geral a introdução da variável independente, metáforas orientadas para valores (Anexo 5), somente era realizada próximo ao fim da sessão, boa parte dos possíveis efeitos dessas só eram notados na sessão seguinte. Por exemplo, na sessão 10, em mais da metade do tempo a cliente recomendou ao terapeuta um lanche em um determinado bar na cidade de São Paulo, que ela teria ido ao final de semana com as amigas, e gostado muito. Contudo, em um dado momento, descreveu que o episódio, bar com as amigas, seria um argumento do motivo de não desejar ter filhos, pois, para ela, crianças seriam um impeditivo para este tipo de programa. Após aprofundamentos sobre o tema, aos 45 minutos da sessão, o terapeuta manejou a Metáfora da tartaruga (Anexo 5). A sessão se encerraria 7 minutos depois.

$\mathrm{Na}$ sessão seguinte, possivelmente após reflexões durante a semana, é possível observar o aumento substancial da categoria CER - na sessão 10 foram $6,23 \%$, enquanto na sessão 11 foram $29,61 \%$. Até que ponto esse aumento pode ser atribuído ao manejo da 
metáfora na sessão anterior é discutível. Todavia, há de se considerar no mínimo a possibilidade dessa o ter influenciado, tal como um efeito posterior, não-imediato.

A categoria cliente estabelece relações também fora analisada separadamente e de acordo com as fases do procedimento experimental, como ilustram as figuras 8 e 9 a seguir.

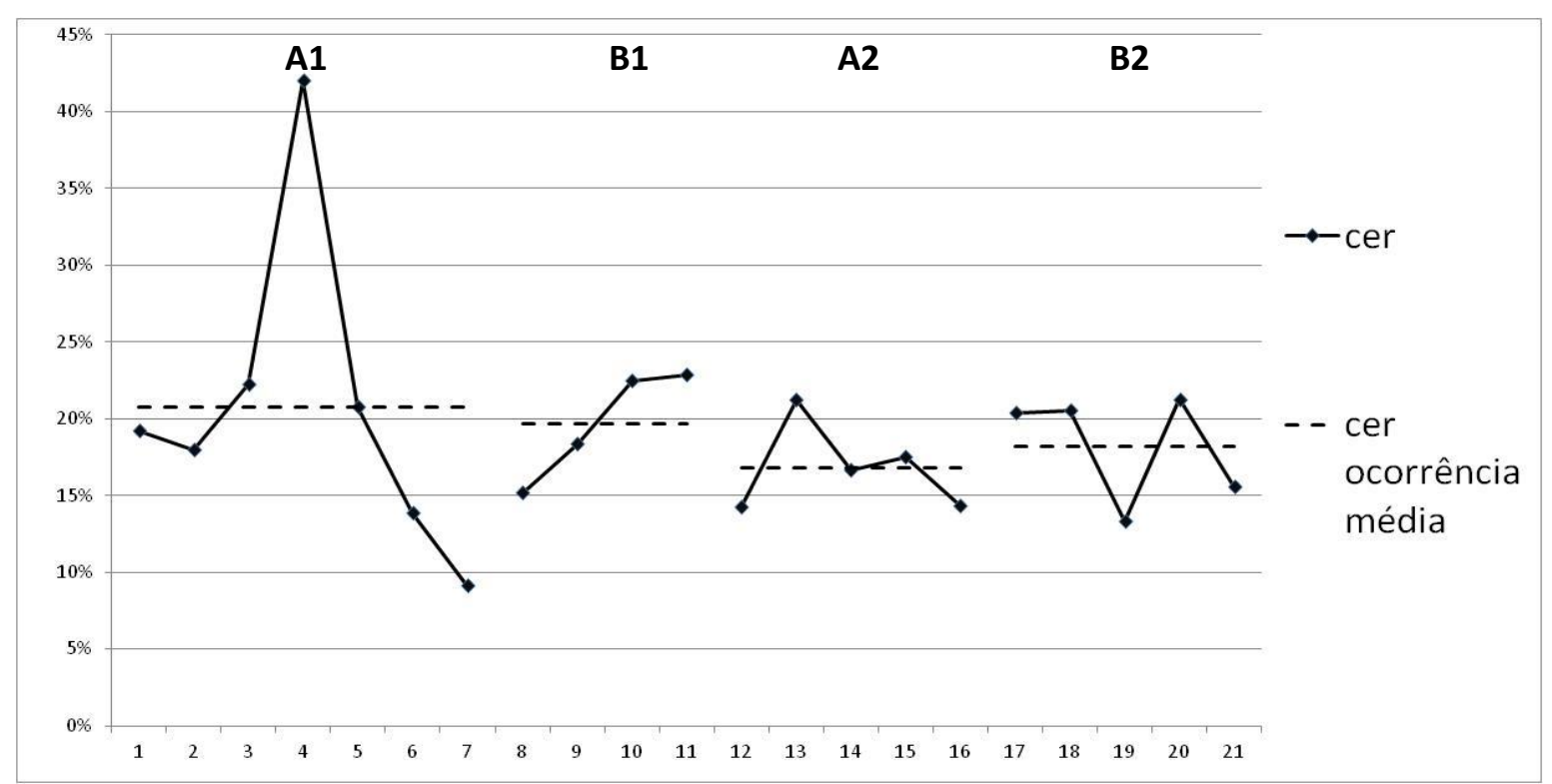

Figura 8. Porcentagens de ocorrência da categoria cliente estabelece relações do cliente e a média da categoria por fase do delineamento.

Aparentemente, utilizando-se a medida de ocorrência, numa primeira inspeção visual, a categoria CER não sofreu grandes alterações pelo procedimento vigente. Com exceção da sessão 4, analisada anteriormente, ela se manteve numa faixa de 9,15\% (sessão 7) à 22,22\% na sessão 11 . Uma amplitude de $13,7 \%$. Poder-se-ia pensar que, no máximo, a instauração do procedimento serviu para "restaurar" a terapia como evocativa, como se observa da sessão 7 para a 8, mas, em um nível semelhante ao da fase A2, por exemplo, quando não foi introduzida a VI do estudo. A diferença da média da fase A1 e da média da fase B2 é de apenas 2,91 pontos percentuais. 
Contudo, ao se observar as mudanças na CER pela medida de duração na Figura 9 adiante algumas outras conclusões podem ser extraídas.

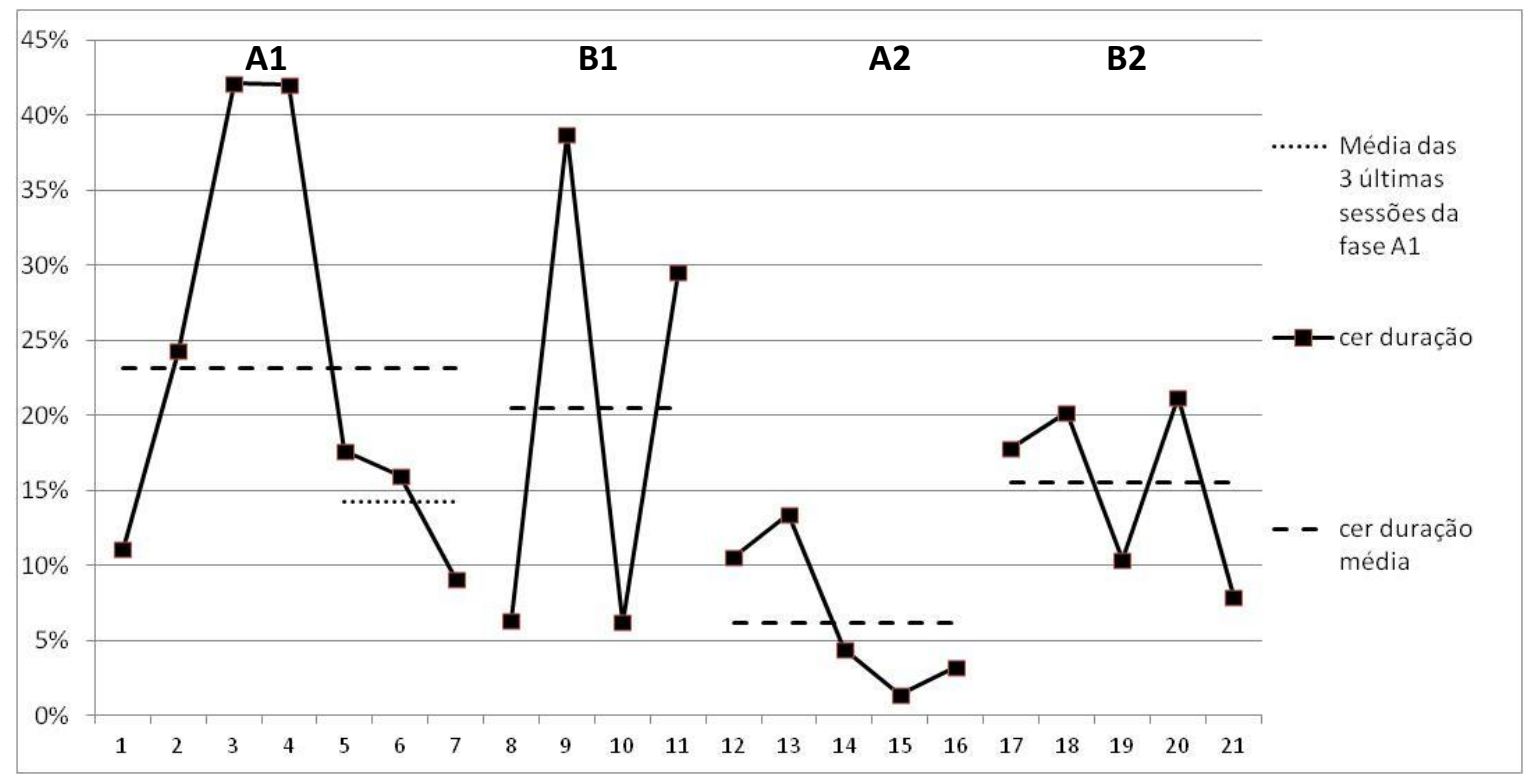

Figura 9. Porcentagens de duração da categoria cliente estabelece relações do cliente, a média da categoria por fase do delineamento e a média das sessões 5, 6 e 7 .

É nítida a mudança na média da categoria, por exemplo, entre as fases B1, com 20,5\%, e A2, com 6,22\%. Tal dado poderia corroborar a hipótese de que o manejo de metáforas poderia contribuir para terapia vir a ser evocativa, tal como sugerido no capítulo 3 .

Entretanto, entre A2 e B2, a diferença não se mostrou tão expressiva. Não obstante, há de se considerar que, como descrito no capítulo 4 "Método", que as sessões dessa fase foram realizadas num período de duas semanas, com apenas dois dias de diferença. Talvez o encurtamento do período de tempo entre as sessões, por conta das férias programadas da cliente e manutenção das sessões do procedimento experimental, por outro lado, possa ter prejudicado a responsividade do terapeuta nessa fase. 
A diferença entre as médias da CER entre as fases A1 e B1 não foram substanciais. Assim, poder-se-ia afirmar neste caso que a introdução da VI produziu uma redução do CER da cliente. Contudo, a literatura de pesquisa clínica, como em Hersen e Barlow (1976) e Kazdin (1982), aponta a possibilidade de vieses no início da pesquisa, como efeitos do registro ou efeito placebo. Nos casos em que ocorrem uma variabilidade comportamental não prevista anteriormente pelo pesquisador, Sidman (1970) recomenda explorar-se a fonte dessa variabilidade. Aparentemente, o fato de a cliente Natália ter sido encaminhada por uma outra terapeuta analítico-comportamental, pode ter elevado as taxas de relações estabelecidas pela cliente nas primeiras sessões. O terapeuta estaria "recuperando" as análises e relações feitas na terapia anterior e a cliente as "restabeleceria" nas sessões iniciais.

De todo o modo, caso desconsidere-se as 4 sessões iniciais para cálculo da média da CER (como indica a linha pontilhada na Figura 9), é possível notar a diferença então da média da categoria CER na fase A1 para a fase B2. Ou, outra possibilidade seria pensar o estudo como um delineamento BAB, a partir da sessão 8, com a introdução da VI.

Independentemente dos possíveis vieses no início da pesquisa, outro dado interessante a se notar é a tendência de decrescente da CER nas últimas sessões da fase A1, sessões 5, 6 e 7, e como na fase B2 a partir da 9 sessão, essa categoria volta a "subir".

Portanto, seja pelos vieses de registro, placebo ou pelo encaminhamento, ou pela tendência decrescente da CER no final da fase A1, e, considerando a diferença das médias da categoria CER entre as fases B1 e B2 e a fase A2, aparentemente o manejo de metáforas no procedimento evocou um estabelecimento de relações maior por parte da cliente nesse processo terapêutico, embora os dados sejam pouco conclusivos. O emprego de análises sequenciais ou estatísticas (de significância, por exemplo) poderiam vir a corroborar ou não esta afirmação. 
Outra possibilidade de análise que poderia contribuir seria a dos temas presentes na sessão, utilizando-se o eixo II do SiMCCIT, por exemplo.

A Figura 10 a seguir apresenta a qualidade das relações estabelecidas pelo cliente por fase do procedimento experimental.

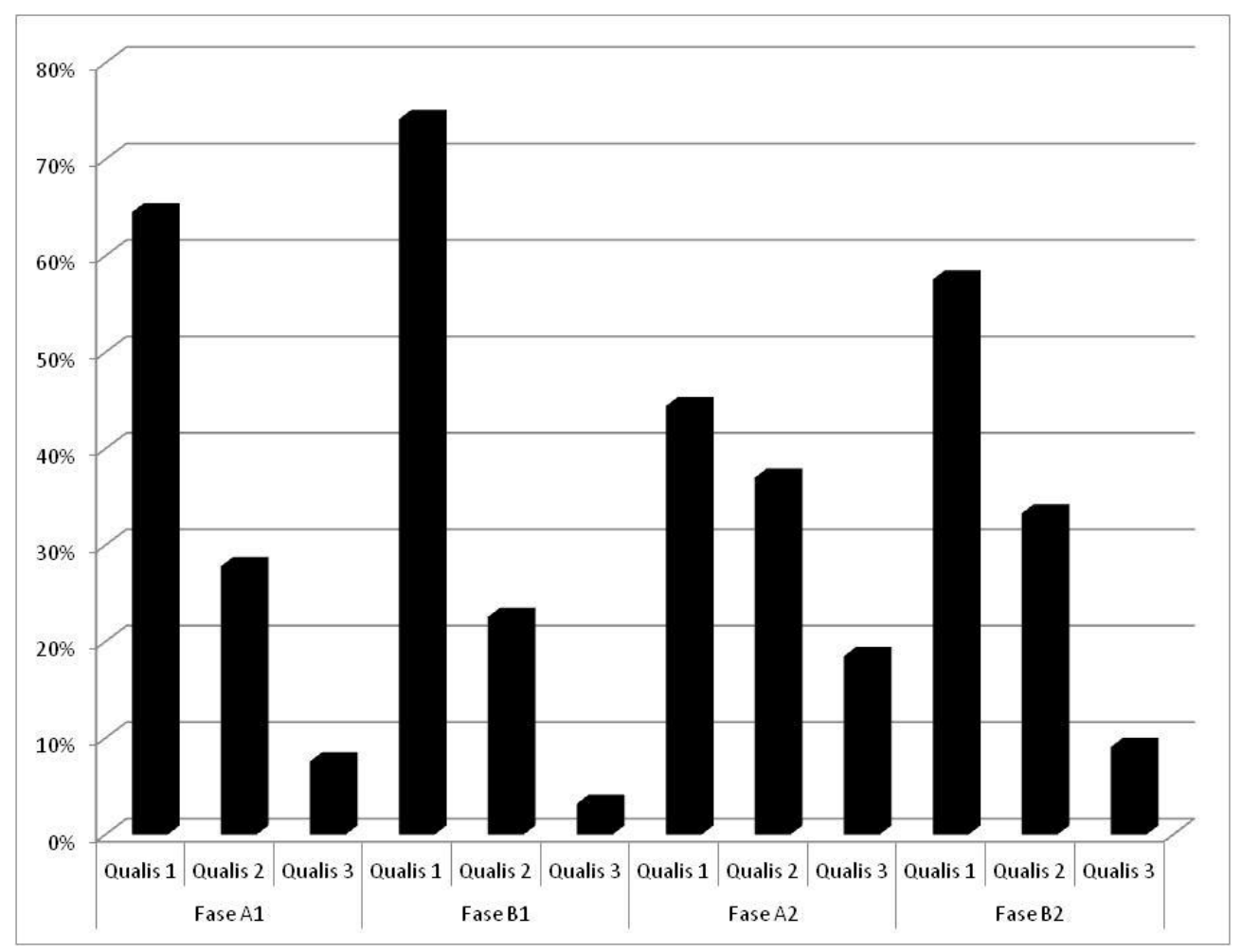

Figura 10. Porcentagens da qualidade das relações estabelecidas pela cliente por fases do procedimento experimental mediante o Qualificadores das Verbalizações de Estabelecimento de Relações de Rodrigues et al (no prelo) modificado.

Como é possível observar na figura 10, aparentemente a qualidade das relações estabelecidas nas sessões não sofreu grandes alterações pelo procedimento experimental. Há um número ligeiramente maior de relações estabelecidas na fase $\mathrm{B} 2$, seis a mais, em comparação à fase A2. Por outro lado, a qualidade das relações na fase A2 parece ser ligeiramente melhor - 37,03\% das relações foram qualis 2 e $18,51 \%$ foram qualis 3 na fase A2, ao passo que, na fase B2, 33,33\% das relações estabelecidas foram consideradas Qualis 2 e 9,09\% equivalentes à qualis 3 . 
Pode-se especular que, talvez nas fases em que houve manejo de metáforas, tenha havido um estabelecimento maior de relações por conta do efeito evocativo dessas, enquanto que nas fases que não houve manejo de metáforas, talvez as relações puderam ser melhores trabalhadas.

Possivelmente por se tratar do início da terapia, em proporção, houve um maior número de relações de qualis 1 na fase A1 do que nas demais fases.

\section{Caracterização de um episódio de manejo de metáfora}

A Tabela 3 a seguir apresenta um trecho recortado da planilha de categorização pelo SiMCITT de uma das sessões da fase B2, um episódio da sessão 8, em que foi manejado uma metáfora orientada para valor da ACT, a metáfora do esquiador (Anexo 5).

\begin{tabular}{|c|c|c|c|c|c|c|c|}
\hline \multirow{2}{*}{$\begin{array}{l}\text { Tempo } \\
00: 11: 11\end{array}$} & \multicolumn{4}{|c|}{ TERAPEUTA } & \multirow{2}{*}{$\begin{array}{c}\text { Tempo } \\
00: 11: 20\end{array}$} & \multicolumn{2}{|c|}{ CLIENTE } \\
\hline & sre & & & & & rel & \\
\hline $00: 11: 33$ & sre & fac & & & $00: 11: 34$ & rel & \\
\hline $00: 11: 45$ & int & sre & fac & apr & $00: 11: 50$ & rel & \\
\hline $00: 12: 24$ & int & sre & int & & $00: 13: 00$ & con & \\
\hline $00: 13: 10$ & int & sre & apr & apr & $00: 13: 30$ & rel & \\
\hline $00: 13: 54$ & int & srf & & & $00: 14: 40$ & rel & \\
\hline $00: 15: 00$ & emp & int & & & $00: 15: 34$ & con & rel \\
\hline $00: 15: 58$ & apr & int & fac2 & & & & \\
\hline
\end{tabular}

Tabela 3. Caracterização do manejo da metáfora do esquiador da ACT de acordo com o SiMCITT.

Neste episódio, pode-se observar a ocorrência sobretudo das categorias SRE e INT do terapeuta e REL do cliente. O estabelecimento de relações por parte da cliente posterior a esse episódio só vai ocorrer a partir do minuto 17, e, com uma duração maior, no final da sessão, 
no minuto 32 e 41 . Tal dado pode novamente corroborar tanto para o efeito pervasivo do comportamento verbal como ao efeito evocativo das metáforas. Mais uma vez pode-se pensar que este último não seria imediato, mas, poderia ser notado nas fases em que estas são manejadas, como foi discutido anteriormente na figura 9.

Dados obtidos das medidas de resultado, o BAI e o EAS 40.

A tabela 4 a seguir apresenta os resultados do Inventário de Ansiedade de Beck utilizado.

\section{INVENTÁRIO DE ANSIEDADE DO BECK - BAI}
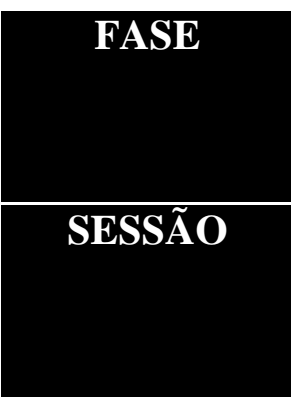

RESULTADO

ANSIEDADE

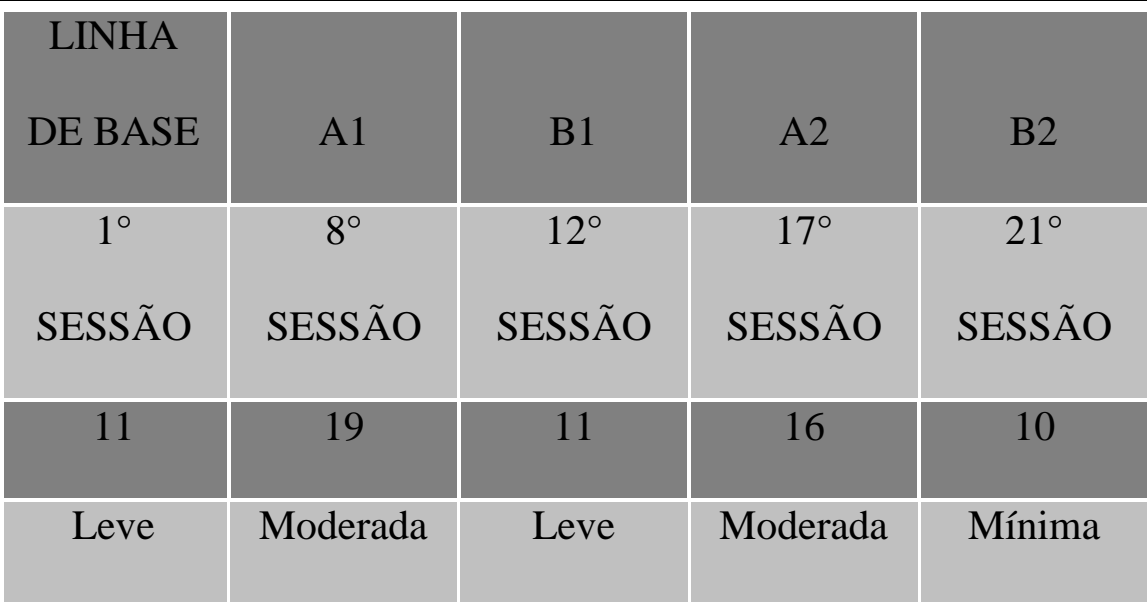

Tabela 4. Resultados do Inventário de Ansiedade do Beck (BAI) por fase do procedimento.

Interessantemente, como pode ser notado na tabela acima, após o término das fases experimentais, sessões 12 e 21, o nível de ansiedade apresentado no BAI era menor do que o apresentado nas fases controle, sessões 8 e 17. Essa redução no nível da ansiedade talvez possa ser atribuída ao fenômeno da transformação de função de estímulos e corroboraria a 
noção defendida por Wilson e Luciano (2002). Ou seja, na medida em que eram evocados e tratados alguns eventos por meio de metáforas, na sessão, outros estímulos perderiam ou teriam seu caráter aversivo atenuado fora dessas.

Pode-se notar também a redução - embora de apenas um ponto - de um nível de ansiedade leve no início da terapia para um nível mínimo no final da sessão 21 .

Pode-se pensar em um possível caráter aversivo ou ansiogênico da terapia nas fases A, em que não há o uso de metáforas. Talvez o fato de alguns temas não estarem sendo abordados na terapia, já que não eram evocados, pudesse estar ligado ao aumento no término dessas fases. A Tabela 5 a seguir apresenta os resultados da Escala de Avaliação de Sintomas, EAS-40.

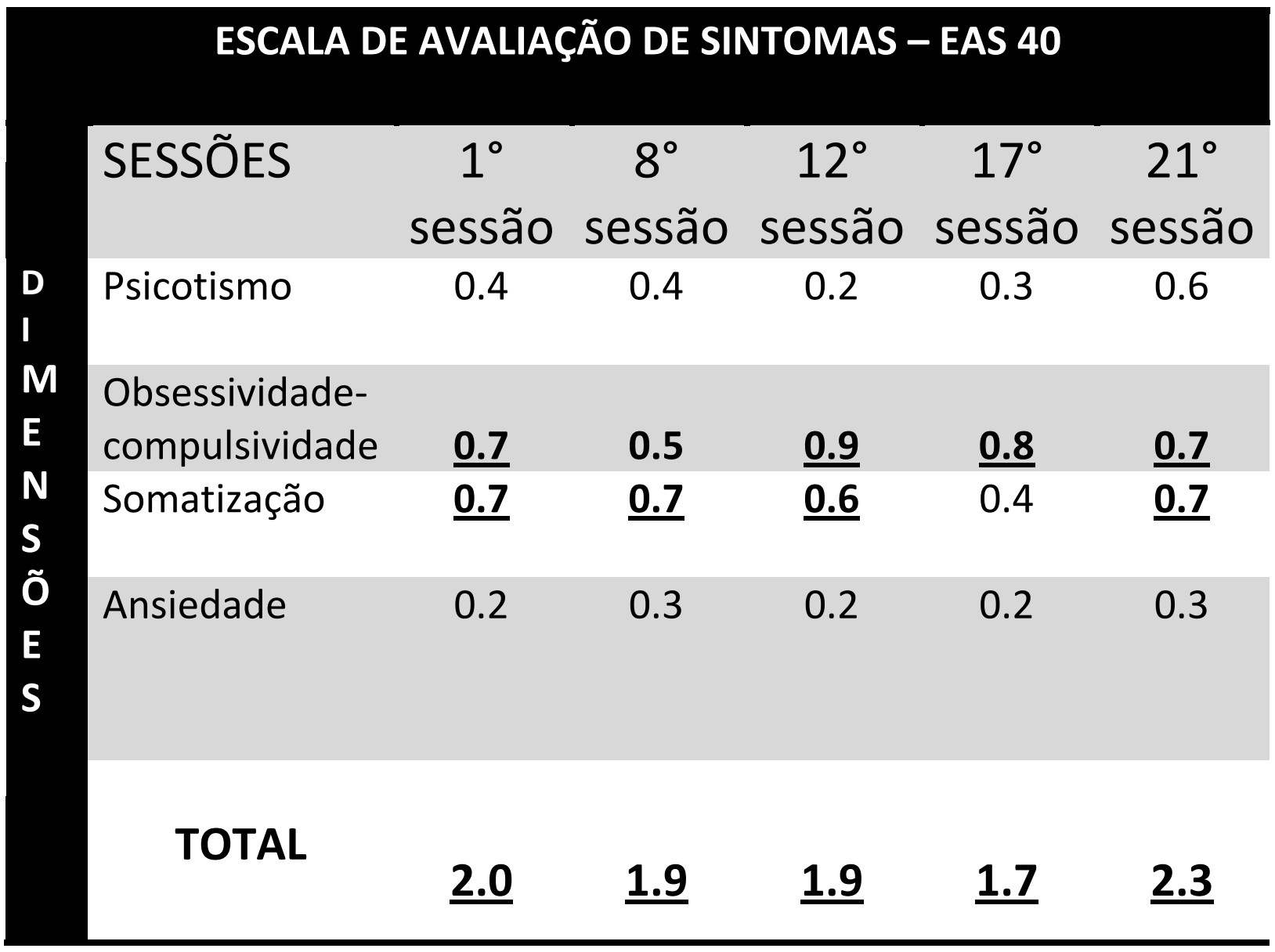

Tabela 5. Resultados da Escala de Avaliação de Sintomas EAS-40 por fase de procedimento experimental. 
Em destaque e sublinhados estão os valores considerados acima da média em cada uma das dimensões e no total. Curiosamente, apesar dos resultados do BAI e da cliente ter sido diagnosticada previamente com Transtorno de Ansiedade Generalizada, a dimensão do EAS-40 que apresentou os menores valores foi ansiedade. Entretanto, alguns itens como o 23 (sentir-se tenso e travado) e o 35 (sentir-se tão agitado que não é capaz de parar quieto), que eram costumeiramente marcados pela cliente como "muito" (equivalente a 0.2 pontos), na escala são atribuídos à dimensão obsessividade-compulsividade. Sendo assim, faz sentido os valores altos dessa dimensão e os valores baixos da ansiedade.

O aumento da dimensão psicotismo na última sessão pode estar ligada ao tema recorrente das últimas sessões, o relacionamento amoroso da cliente. Pela primeira vez itens como "não se sentir próximo", "envolver-se em discussões" ou "sentir-se sem importância" foram assinalados.

Semelhantemente, o aumento na dimensão somatização pode estar ligado ao fato da cliente ter realizado recentemente um procedimento médico invasivo, uma cirurgia no trato urinário, preocupada e angustiada com fraquezas ou dores. Tal cirurgia pode ter enviesado também o aumento no total na sessão 21 .

Por fim, reitera-se o argumento de que, aparentemente, o manejo de metáforas no procedimento evocou um estabelecimento de relações maior por parte da cliente e uma redução na ansiedade (segundo o BAI) nas fases em que metáforas eram manejadas, embora a qualidade das relações estabelecidas nas fases em que não houve manejo de metáforas foi superior, embora os dados sejam pouco conclusivos. Talvez o uso de análises seqüenciais ou estatísticas (de significância, por exemplo) poderiam vir a corroborar ou não esta afirmação. De qualquer maneira, o estudo aponta a possibilidade de que metáforas podem ser investigadas sistematicamente usando metodologia experimental. 
Cabe questionar quais efeitos outras metáforas poderiam produzir, assim como, se o uso de outro sistema de categorização poderia ser interessante. 


\section{CONCLUSÃO}

O presente estudo teve como objetivo investigar os efeitos do manejo de metáforas orientadas para valores sobre o repertório de uma cliente diagnosticada com transtorno de ansiedade generalizada através de um delineamento experimental de caso único na clínica. Neste, argumenta-se que o manejo de metáforas no procedimento evocou um maior estabelecimento de relações por parte da cliente em fases em que estas eram manejadas, em comparação a fases nas quais não eram, como consta na figura 9. Contudo, este estudo se limitou a não explorar quais relações foram propiciadas, favorecidas, ou, de que maneira as relações (implícitas) nas metáforas evocaram o estabelecimento de novas relações por parte da cliente.

Sendo assim, embora sugestivos, os dados ainda são pouco conclusivos. Há de se considerar também o problema da generalidade dos resultados ou da validade externa de pesquisas de caso único, sejam estas experimentais, como neste caso, ou narrativas (Barlow, 2009).

Possivelmente o uso de análises sequenciais ou estatísticas (de significância, por exemplo) poderiam vir a corroborar ou não esta afirmação ou os achados desse trabalho. De qualquer maneira, o estudo aponta a possibilidade de que metáforas podem ser investigadas sistematicamente na clínica utilizando-se uma metodologia experimental. Cabe questionar quais efeitos outras metáforas poderiam produzir, assim como, se o uso de outro sistema de categorização poderia ser interessante na análise dos dados. Sugere-se também conduzir uma revisão das categorias SiMCCIT, ou, de que maneira metáforas poderiam vir a ser contempladas além da categoria interpretação do terapeuta, como é previsto no manual de 2007. 
Paralelamente, se as análises não demonstrassem alguma significância estatística, caso fossem submetidas a algum de cálculo de significância, cabe questionar se, na medida em que relações foram estabelecidas nas sessões nas fases em que metáforas foram manejadas, e que estas se tornaram temas na sessão e influenciaram a tomada de decisões do terapeuta, se estas poderiam vir a ser consideradas com alguma significância clínica (Barlow, 2009).

Cabe assinalar que o uso de um categorizador das sessões, para o sistema multidimensional de categorização de comportamentos na interação terapêutica - SiMCCIT, pôde vir a contribuir como um atenuante de possíveis vieses que a categorização por parte do pesquisador poderia agregar.

Em estudos clínicos nos quais o terapeuta e o pesquisador são a mesma pessoa, poderse-ia considerar a possibilidade de um viés de performance do terapeuta/pesquisador, ou seja, esse poderia ter se comportado de modo a favorecer a hipótese da pesquisa. Contudo, a ausência de solicitações de reflexões em determinadas sessões experimentais, a alta correlação entre SRF e CER independentemente da fase, assim como um categorizador independente e um bom índice de concordância entre esse e o pesquisador/terapeuta sugerem que isso não ocorreu.

Ademais, o uso de observações repetidas e contínuas (registro e categorização de cada uma das sessões no estudo), a avaliação da linha de base e o critério de estabilidade nesta e para as mudanças de fases, assim como a replicação direta, permitem demonstrar confiabilidade e generalidade dos dados, que contribuíram para uma boa validade interna da pesquisa.

Para Kazdin (1982), tais características desta pesquisa a configurariam como um estudo de caso do tipo II. Para ser considerada um estudo de tipo III, o tipo com maior grau de validade interna, esta teria que conter múltiplos casos. Inicialmente esta pesquisa contaria 
com mais uma participante, outra cliente, mas esta abandonou a terapia no decorrer do procedimento, ainda na linha de base.

Enquanto que, para Kratochwill (2013), essa pesquisa atende aos critérios com reservas. Isso porque a fase B1 possui quatro sessões e não cinco. Vale ressaltar que o acesso a esse artigo foi posterior ao início da coleta e o procedimento foi alterado para se adequar ao que é proposto na referida publicação.

Semelhantemente, para a APA (2006) uma série de casos seria necessária para se avaliar qualquer efetividade do manejo de metáforas para ansiedade.

Em 1968, na época no lançamento do primeiro número do Journal of Applied Behavior Analysis, e posteriormente em 1987, Baer, Wolf e Risley analisaram a produção analítico-comportamental de pesquisas aplicadas e também estabeleceram critérios qualitativos para tal. De um modo geral, os critérios remetem às características descritas anteriormente, talvez com outros nomes, e consideradas importantes pelos outros autores, como Kazdin (1982) e Kratochwill (2013). Quanto ao critério generalidade, problema citado anteriormente, poder-se-ia ter utilizado outras medidas de registro extraconsultório, além do BAI e EAS-40.

Teria sido interessante também realizar alguma sondagem posterior à última fase do procedimento, um follow up. Contudo, esta etapa foi impraticável por conta do desejo da cliente em permanecer em terapia após o término da pesquisa. Outras replicações, sistemáticas dessa vez, com outros clientes, outros terapeutas - quem sabe com outras metáforas e em outros ambientes, talvez até extraconsultórios - poderiam ser ainda mais esclarecedores. 
De todo modo, por generalização lógica (Barlow, 2009), é possível pensar metáforas, ao menos as orientadas para valores, como um recurso interessante, talvez um facilitador, que poderia ser conciliado com outras intervenções sistematizadas, sobretudo em clientes com queixas difusas ou padrões de esquiva bem estabelecidos.

Evidentemente, como toda técnica, esta deveria ser pensada com parcimônia, levandose em conta variáveis clínicas, do terapeuta e do cliente antes de qualquer uso (APA, 2006). Para o terapeuta, ficou a sensação de que, por vezes, as metáforas cansaram a cliente - talvez seu uso sistematizado tenha contribuído nesse sentido. Por outro lado, cabe atentar à capacidade de abstração do cliente, ou, deste estabelecer relações verbalmente. Sugere-se que o manejo de metáforas em atendimento a clientes com desenvolvimento atípico precisa ser avaliado com cautela / é desencorajado. 


\section{REFERÊNCIAS}

Abreu e Silva, M. C. (2012). Metáfora e terapia analítico-comportamental: revisão de estudos brasileiros e verificação de seus prováveis efeitos. Dissertação de mestrado, Programa de Pós-Graduação em Psicologia, Universidade Federal do Paraná, Curitiba.

American Psychological Association. (2006). Evidence-based practice in psychology. American Psychologist, 61 (4), 271-285.

American Psychological Association (2013). Recognition of Psychotherapy Effectiveness. Psychotherapy, 50, 102-109.

Banaco, R. A. (1999). O acesso a eventos encobertos na prática clínica: Um fim ou um meio? Revista Brasileira de Terapia Comportamental e Cognitiva, 1(2), 135-142.

Baer, D.M., Wolf, M.M., \& Risley, T.R. (1968). Some current dimensions of applied behavior analyis. Journal of Applied Behavior Analysis. 1, 91-97.

Baer, D. M., Wolf, M. M., \& Risley, T. R. (1987). Some still-current dimensions of applied behavior analysis. Journal of Applied Behavior Analysis, 20, 313-327.

Beck, A. T., Epstein, N., Brown, G., \& Steer, R. A. (1988). An inventory for measuring clinical anxiety: psychometric properties. Journal of Consulting and Clinical Psychology, 56, 893-897.

Blackledge, J.T. (2003). An Introduction to Relational Frame Theory: Basics and Applications. The Behavior Analyst Today, 3(4), 421-433

Catania, A. C. (2006) Words as behavior. The Analysis of Verbal Behavior, 22, 87-88.

Chambless, D. L., Baker, M., Baucom, D. H., Beutler L. E, Calhoun K. S., Crits-Christoph, P., . . W Woody, S. R. (1998). Update on empirically validated therapies, II. The Clinical Psychologist, 51(1), 3-16

Chambless, D., \& Ollendick, T. (2001). Empirically supported psychological interventions: Controversies and evidence. Annual Review of Psychology, 52, 685-716.

Costa, N. (2011). O surgimento de diferentes denominações para a terapia comportamental no Brasil. Revista Brasileira de Terapia Comportamental e Cognitiva, 13 (2), 46-57.

Cunha, J. (2001). Manual em português das Escalas Beck. São Paulo: Casa do Psicólogo.

Donahoe, T. W. (1998). Interpreting Verbal Behavior. The analysis of Verbal Behavior, 9, 107-112

Dougher, M. J. (2000). Clinical Behavior Analysis. Reno, NV: Context Press.

Drash, P. W. \& Tudor, R. M. (1991) A standard methodology for the analysis, recording and control of verbal behavior. The analysis of Verbal Behavior, 9, 49-60.

Dymond, S., May, R. J., Munnelly, A. \& Hoon, A. E. (2010). Evaluating the evidence base for relational frame theory: A citation analysis. The Behavior Analyst, 33, 97-117.

Dymond, S. \& Roche B. (2012). Advances in relational frame theory and contextual behavioral science. Oakland: New Harbinger.

Eifert, G. H. \& Forsyth, J. P. (2005). Acceptance and Commitment Therapy for anxiety disorders. Oakland, CA: New Harbinger.

Eifert, G. H., \& Heffner, M. (2003). The effects of acceptance versus control contexts on avoidance of panic-related symptoms. Journal of Behavior Therapy and Experimental

Psychiatry, 34, 293-312

Eifert, G. H., \& Plaud, J. J. (1998). From behavior theory to behavior therapy: An overview. In J. J. Plaud \& G. H. Eifert (Eds.), From behavior theory to behavior therapy (pp. 114). Boston: Allyn and Bacon.

Eshleman, J. W. (1991). Quantified trends in the history of verbal behavior research. The Analysis of Verbal Behavior, 9, 61-80. 
Eysenck, H. J. (1952). The effects of psychotherapy: An evaluation. Journal of Consulting Psychology, 16, 319-324

Fidalgo, A. P. (2011) O estudo do comportamento verbal no Brasil: uma análise com base em resumos de dissertações e teses. Dissertação de mestrado. Programa de estudos Pòsgraduados em Psicologia Experimental: Análise do Comportamento, PUC-SP, São Paulo, Brasil.

Fisch, G. S. (1998). Visual inspection of data revisited: Do the eyes still have it? The Behavior Analyst, 21 (1), 111-123.

Fisch, G. S. (2001). Evaluating data from behavioral analysis: Visual Inspection or statistical model? Behavioural Processes, 54, 137-154.

Foody, M., et al (2014). RFT for clinical use: The example of metaphor. Journal of Contextual Behavioral Science, (3) 4, 305-313.

Forsyth, J. P., \& Hawkins, R. P. (1997). Introduction to the special issue thirty years of behavior therapy: Promises kept, promises unfulfilled. Behavior Therapy, 28, 327-331.

Foucault, M. (1994) Doença Mental e psicologia. $5^{\circ}$ Edição, Rio de Janeiro, RJ: Tempo Brasileiro, Trabalho original publicado em 1962.

Hayes, S. C., Strosahl, K. D., \& Wilson, K. G. (1999). Acceptance and commitment therapy: An experiential approach to behavior change. New York: Guilford Press.

Hayes, S. C. (2004). Acceptance and Commitment Therapy and the new behavior therapies: Mindfulness, acceptance and relationship. In S. C. Hayes, V. M. Follette, \& M. Linehan (Eds.), Mindfulness and acceptance: Expanding the cognitive behavioral tradition (pp. 1-29). New York: Guilford.

Hayes, S. C., Masuda, A., Shenk, C., Yadavaia, J. E., Boulanger, J., Vilardaga, R., Plumb, et al. (2007). Applied extensions of behavior principles: Applied behavior al concepts and behavioral theories. In D. Woods \& J. Kantor (Eds.), Understanding behavior disorders: A contemporary behavior analytic perspective (pp. 47-80). Reno, NV: Context Press

Hersen, M. \& Barlow, D. H. (1976). Single Case Experimental Designs: Strategies for Studying Behavior Changes. New York: Pergamon

Horvath, A. O., e Symonds, B. D. (1991). The relation between working alliance and outcome in psychotherapy: A meta-analysis. Journal of Counseling Psychology, 38, 139-149.

Glenn, S. S. (1989). Verbal behavior and cultural practices. Behavior Analysis and Social Action, 7 (1), 10-15.

Guedes, M. L. (1993). Equívocos em terapia comportamental. Temas em Psicologia, 2, 81-85.

Greenberg, L. S. \& Pinsof, W. M. (1986). The Psychotherapeutic Process: A Research Book. New York: The Guilford Press.

Grow, L. L. \& Kodak, T. (2010) Recent research on emergent verbal behavior: Clinical applications and future directions. Journal of Applied Behavior Analysis, 43 (4), 775778.

Kazdin, A. E. (1982). Single-Case Research Designs: Methods for Clinical and Applied Settings. Cambridge: Oxford University Press.

Kazdin, A. E. (2007). Mediators and mechanisms of change in psychotherapy research. Annual Review of Clinical Psychology, 3, 1-27.

Kerbauy, R. R. (2011). Análise do comportamento: Princípios e flexibilidade com as contingências. Boletim Contexto, 34, São Paulo, 28-32.

Kohlenberg, R. J., \& Tsai, M. (2001). Psicoterapia Analítica Funcional: Criando Relações Terapêuticas Intensas e Curativas. Santo André: ESETec. (trabalho original publicado em 1991).

Kohlenberg, R. J., Tsai, M., García, R. F., Aguayo, L. V., Parra, A. F. \& Virués-Ortega, J. (2005). Psicoterapia analítico-funcional y terapia de aceptación y compromiso: Teoría, 
aplicaciones y continuidad con el análisis del comportamiento. International Journal of Clinical and Health Psychology, 5 (2), 349-371.

Kovac, R. Zamignanni, D. R., \& Avanzi, A. L. (2009). Análise do comportamento verbal relacional e algumas implicações para a clínica analítico-comportamental. In R. C. Wielenska (Org.), Sobre comportamento e cognição: Desafios, soluções $e$ questionamentos, Vol. 24 (pp. 314-324). Santo André: ESETec Editores Associados.

Kratochwill, T. R., Hitchcock, J. H., Horner, R. H., Levin, J. R., Odom, S. L., Rindskopf, D. M. \& Shadish, W. R. (2013). Single-case intervention research design standards. Remedial and Special Education, 34 (1), 26-38.

Laloni, D. T. (2001). Escala de Avaliação de Sintomas-90-R SCL-90-R: adaptação, precisão $e$ validade. Tese de Doutorado não publicada, Campinas: Pontifícia Universidade Católica de Campinas.

Leigland, S. (1998). The methodological challenge of the functional analysis of verbal behavior. The Analysis of Verbal Behavior, 15, 125-127.

Leigland, S. (2005). Variables of Which Values Are a Function. The Behavior Analyst, 28 (2), 133-142.

Lipkens, R. \& Hayes, S. C. (2009). Producing and recognizing analogical relations. Journal of the Experimental Analysis of Behavior, 91, 105-126.

Luoma, J. B., Hayes, S. C. \& Walser, R. D. (2007). Learning ACT: An acceptance \& commitment therapy skills-training manual for therapists. Oakland, CA: New Harbinger Publications.

McCurry, S. M. \& Hayes, S. C. (1992) Clinical and experimental perspectives on metaphorical talk. Clinical Psychology Review, 12, 763-785.

McMullen, J., Barnes-Holmes, D., Barnes-Holmes, Y., Stewart, I., Luciano, C. \& Cochrane, A. (2008). Acceptance versus distraction: Brief instructions, metaphors, and exercises in increasing tolerance for self-delivered electric shocks. Behaviour Research and Therapy, 46, 122-129.

Meyer, S. B. (1995) Quais os requisitos para que uma terapia seja considerada comportamental? Retirado em 12/2012, http://www.inpaonline.com.br/artigos.

Meyer, S. B. (2000). Mudamos, em terapia verbal, o controle de estímulos? . Acta Comportamentalia, Mexico, 8, n. 2, p. 215-225.

Meyer, S., Oshiro, C., Donadone, J., Mayer, R. C. F., Starling, R. (2008). Subsídios da obra "Comportamento Verbal" de B. F. Skinner para a terapia analítico-comportamental. Revista Brasileira de Terapia Comportamental e Cognitiva, 10 (1), 105-118.

Meyer, S. B. (2009). Análise de 'solicitação de informação' e 'recomendação' em banco de dados de terapias comportamentais. Tese de livre-docência. Instituto de Psicologia, Universidade de São Paulo, São Paulo, Brasil.

Michael, J. (1982) Distinguishing between discriminative and motivational functions of stimuli. Journal of the Experimental Analysis of Behavior. 37, 149-155.

Migone, P. (1996). La ricerca in psicoterapia: Storia, principali gruppi de lavoro, stato attuale degli studi sul risultato e sul processo. Rivista Sperimentale di Freniatria, 2, 182-238.

Pérez Álvarez, M. P. (1996). La psicoterapia desde el punto de vista conductista. Madri, ESP: Editorial Biblioteca Nueva.

Pérez Álvarez, M. P. (2006). La Terapia de Conducta de Tercera Generación. EduPsykhé, 5 (2), 159-172.

Perez, W. F.; Nico, Y. C.; Kovac, R. Fidalgo, A. P.; Leonardi, J. L. (2014). Introdução à teoria das molduras relacionais (relational frame theory): Principais conceitos, achados experimentais e possibilidades de aplicação. Revista Perspectivas em Análise do Comportamento, 4 (1), 32-50. 
Peuker, A. C., Habibzang, L. F., Koller, S. H., Araujo, L. B. (2009). Avaliação de processo e resultado em psicoterapias: Uma revisão. Psicologia em Estudo, 14 (3), 439-445.

Pheula, G. F., \& Isolan, L. R. (2007). Psicoterapia baseada em evidências em crianças e adolescentes. Revista Psiquiatria Clínica, 34 (2), 74-83.

Psychological Treatments (n. d.) Lista de tratamentos psicológicos empiricamente suportados e atualizados pela Society of Clinical Psychology, divisão 12 da APA. Recuperado em 12 de maio de 2014, de http://www.div12.org/PsychologicalTreatments/treatments.html

Reed, D. D. \& Luiselli, J. K. (2009). Antecedents to a paradigm: Ogden Lindsleyand B. F. Skinner's founding of "BehaviorTherapy". The Behavior Therapist, 32 (4), 82-85.

Roche, B., Forsyth, J. P., \& Maher, E. (2007). The impact of demand characteristics on brief acceptance and control-based interventions for pain tolerance. Cognitive and Behavioral Practice, 14, 381-393.

Rodrigues et al (no prelo) Efeitos de intervenções reflexivas sobre o repertório do cliente no processo terapêutico analítico-comportamental.

Ruiz, F. J. \& Luciano, C. (20 12). Relacionar relaciones como modelo analítico-funcional de la analogía y la metáfora. Acta Comportamentalia, 20, 5-31.

Russel, R. L., \& Trull, T. (1986). Sequential analyses of language variables in psychotherapy process research. Journal of Consulting and Clinical Psychology, 54(1), 16-21.

Sidman, M. Tactics of Scientific Research. New York: Basic Books, 1960.

Stiles, W. B. (1999). Signs and voices in psychotherapy. Psychotherapy research, 9 (1), 1-21.

Suen, H. K. \& Ary, D. (1989). Analyzing quantitative behavioral observation data. Lawrence Erlbaum Associates: New Jersey.

Skinner, B. F. (1957). Verbal behavior. New York: Appleton-Century-Crofts.

Skinner, B.F. (2003). Ciência e comportamento humano. São Paulo: Martins Fontes. Trabalho original publicado em 1953.

Smith, J. D. (2012). Single-case experimental designs: A systematic review of published research and current standards. Psychological Methods, 17 (4), 510-550

Stewart, I., \& Barnes-Holmes, D. (2001). Understanding metaphor: A relational frame perspective. The Behavior Analyst, 24, 191-199.

Sturmey, P. (1996). Functional analysis in clinical psychology. Chichester: John Wiley \& sons.

Sturmey, P. (2007). Functional Analysis in Clinical Treatment. San Diego (CA): Academic Press.

Todorov, J. C. (2012). Sobre uma definição de comportamento. Revista Perspectivas em Análise do Comportamento, 3 (1), 32-37.

Törneke, N. (2010). Learning RFT: An introduction to relational frame theory and its clinical applications. Oakland, CA: New Harbinger Publications, Inc

Törneke, N., Luciano, C. \& Salas, S. V. (2008). Rule-governed behavior and psychological problems. International Journal of Psychology and Psychological Therapy, 8(2), 141156.

Tourinho, E. Z. (2006). Private stimuli, covert responses and private events: Conceptual remarks. The Analysis of Verbal Behavior, 29 (1), p. 13-31.

Tourinho, E. Z. (2012). Analogias, metáforas e cognições - comentários a partir do artigo de Ruiz e Luciano. Acta Comportamentalia, 20, (4), p. 32-37.

Tsai, M., Kohlenberg, R. J., Kanter, J. W., Kohlenberg, B., Follette, W. C., \& Callaghan, G. M. (2009). A guide to Functional Analytic Psychotherapy: Awareness, courage, love, and behaviorism. New York: Springer.

Vandenberghe, L. (2011) Terceira onda e terapia analítico-comportamental: um casamento acertado ou companheiros de cama estranhos? Boletim Contexto, 34, São Paulo, 33-41. 
Wilson, K. G., \& Luciano, C. (2002). Terapia de Aceptación y Compromiso: Un Tratamiento conductual orientado a los valores. Madrid: Pirámide.

Zamignani, D. R. (2007). O desenvolvimento de um sistema multidimensional para a categorização e análise de comportamentos na interação terapeuta-cliente. Tese de doutoramento. Instituto de Psicologia, Universidade de São Paulo, São Paulo, Brasil.

Zamignani, D. R. (2011). Comportamentos verbais do terapeuta no sistema multidimensional para a categorização de comportamentos na interação terapêutica (SiMCITT). Revista Perspectivas em Análise do Comportamento, 2 (1), 25-45. 


\section{ANEXO 1 \\ TERMO DE CONSENTIMENTO LIVRE E ESCLARECIDO PARA CLIENTES}

Prezado cliente,

Somos estudante de mestrado e professora do Laboratório de Terapia Comportamental do Instituto de Psicologia da Universidade de São Paulo e estamos estudando o processo de mudança do cliente na terapia.

Para isso estamos solicitando a sua permissão para participar de um projeto de pesquisa que será conduzido por mim, Emerson F. Simões Filho, sob orientação da Profa. Dra. Sonia Beatriz Meyer.

Para que você possa decidir se pode colaborar conosco, procuramos esclarecer resumidamente, a seguir, o que será feito. Se depois de ler, você tiver dúvidas e quiser esclarecimentos, estaremos à sua disposição, por telefone ou e-mail.

Esta pesquisa tem como objetivo estudar intervenções realizadas por metáforas na psicoterapia. Estas serão priorizadas, ou não, em alguns momentos do processo, para que estes possam ser comparados.

O atendimento psicoterápico será estruturado com sessões semanais de 50 minutos e será realizada na sala de atendimento oferecida pelo Laboratório de Terapia Comportamental que se localiza na Clínica-escola do Instituto de Psicologia da Universidade de São Paulo. O atendimento prosseguirá por um período de cerca de 6 (seis) meses e poderá continuar, se você cliente desejar, por mais algumas sessões, que a depender da disponibilidade do terapeuta poderá ser de até (mais) seis meses. Se houver a necessidade, após o término deste período, o encaminhamento para outro terapeuta poderá ser realizado.

As sessões no Laboratório de Terapia Comportamental serão filmadas e gravadas por uma câmera situada na parte superior da sala. A interrupção da gravação poderá ser solicitada e avaliada a qualquer momento.

As informações prestadas por você durante os atendimentos e as gravações de sessões serão utilizadas para fins didáticos e de pesquisa, incluindo publicações científicas. Além disso, tais informações são de fundamental importância para o processo terapêutico e serão utilizadas pelo terapeuta para a condução do mesmo. Essas informações serão tratadas de forma confidencial e os seus dados de identificação não serão divulgados em hipótese alguma. Somente os pesquisadores do grupo terão acesso às filmagens, sendo que todos assumirão o compromisso de absoluto sigilo sobre qualquer informação pertencente às sessões.

Se você concordar com a sua participação, caso sinta qualquer desconforto proveniente da pesquisa, você poderá suspender o processo terapêutico a qualquer momento. Será importante que 
você nos comunique sobre a desistência. Você poderá, a qualquer momento, discutir conosco qualquer questão ou dúvida e retirar seu consentimento, caso considere necessário. A retirada do consentimento não acarretará em qualquer prejuízo ou penalização a você. A não aceitação deste termo e/ou sua retirada futura não implica em qualquer prejuízo a você, sendo que seu direito de atendimento será garantido. O terapeuta continuará o atendimento ou o encaminhará a outro terapeuta, que se comprometerá a atendê-lo sem nenhum custo adicional. Qualquer informação adicional acerca desta pesquisa poderá ser obtida junto aos pesquisadores por meio do e-mail emersonfsf@gmail.com ou dos telefone: (11) 96361-7010 e (11) 99393-3325, ou ainda no endereço Av. Prof. Mello Moraes, 1721, Bloco F sala 121, Cidade Universitária - São Paulo, SP.

\section{Cordialmente,}

Emerson Figueirêdo Simões Filho

Psicólogo e aluno de mestrado no Programa de

Psicologia Clínica
Dra. Sonia B. Meyer

Professora do Programa de Psicologia Clínica

$\mathrm{Eu}$,

R.G.: participarei do projeto de pesquisa descrito acima e declaro que estou ciente e concordo com as condições apresentadas.

São Paulo, de. de 20

Assinatura do cliente: 


\section{ANEXO 2 \\ TERMO DE COMPROMISSO E RESPONSABILIDADE}

Prezado categorizador,

O presente trabalho intitulado "Manejo de metáforas em psicoterapia analítico-comportamental" é uma pesquisa de mestrado do psicólogo Emerson Figueirêdo Simões Filho e está sob orientação da Profa. Dra. Sonia Beatriz Meyer, da Universidade de São Paulo. É importante que algumas condições sejam respeitadas para garantir a proteção do cliente e do material utilizado:

1. Apenas eu poderei ter acesso ao conteúdo das sessões e dos registros;

2. Deverei guardá-los e manuseá-los em local seguro protegido da observação de terceiros;

3. Manter sigilo absoluto sobre toda e qualquer informação mantida nos registros que tive acesso, como por exemplo, identidade do terapeuta e do cliente, dados pessoais de ambos;

4. Comprometer-me a devolver todo o material utilizado sem efetuar cópias ou duplicações e sem qualquer tipo de violação do material original.

$\mathrm{Eu}$,

portador

do

RG realizando a atividade de

para a pesquisa descrita acima me comprometo a respeitar as condições definidas nesse termo.

/ I

Data

Assinatura

Assinatura do Pesquisador 
Nome:

Idade: Data de nascimento:

Data 1

Sexo:

M<smiles>FC1CCC1</smiles>

Estado civil:<smiles>O[SiH2][SeH2]C1CCC1</smiles><smiles>O=[13CH][13CH][13CH]1CC1</smiles><smiles></smiles><smiles>C1C[C@H]2CC[C@H]1O2</smiles>

Grau de escolaridade:

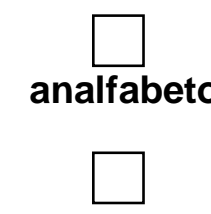

$2^{\circ}$. Grau<smiles>[Te][Te]1CCC1</smiles><smiles>C[Se]1CCC1[Se]</smiles>

\section{ORIENTAÇÔES:}

1- Preencha os dados da identificação na parte superior da folha.

2- Use um lápis preto para marcar a resposta.

3- Se você desejar alterar sua resposta, apague com cuidado a $1^{\text {a }}$. marca e marque a nova resposta.

4- Não faça outras anotações fora dos círculos.

\section{INSTRUÇÕES:}

A escala pode ser administrada nas duas formas, respondida pelo indivíduo sem ajuda do aplicador e respondida com ajuda do aplicador para a leitura dos itens.

Informe ao cliente que será apresentada uma lista de problemas que as pessoas algumas vezes têm. Por favor, leia-os cuidadosamente e pinte o círculo que melhor descreve o quanto aquele problema o tem preocupado ou anqustiado durante os últimos 7 dias incluindo hoje. Pinte o círculo em apenas um número para cada problema e não pule nenhum item. Se mudar de idéia apague a primeira marca e remarque o outro círculo. Leia o exemplo antes de começar. 


\section{EXEMPLO}

\begin{tabular}{|c|c|c|l|}
\hline $\begin{array}{c}\text { Nenhum } \\
\text { Pouco }\end{array}$ & $\begin{array}{c}\text { Um } \\
\text { Pouco }\end{array}$ & Muito & O quanto você está preocupado com: \\
\hline 0 & 1 & 2 & Dores no corpo \\
\hline
\end{tabular}

\section{PROTOCOLO}

\begin{tabular}{|c|c|c|c|c|}
\hline No. & $\begin{array}{c}\text { Nenhum } \\
\text { Pouco }\end{array}$ & $\begin{array}{c}\text { Um } \\
\text { Pouco }\end{array}$ & Muito & O quanto você está preocupado com: \\
\hline 1 & 0 & 1 & 2 & Fraqueza ou tonturas \\
\hline 2 & 0 & 1 & 2 & Dores no coração ou no peito \\
\hline 3 & 0 & 1 & 2 & Sentir medo em espaços abertos ou nas ruas \\
\hline 4 & 0 & 1 & 2 & Pensamentos de acabar com a própria vida \\
\hline 5 & 0 & 1 & 2 & Repentinamente sentir medo sem razão \\
\hline 6 & 0 & 1 & 2 & Ter medo de sair de casa sozinho \\
\hline 7 & 0 & 1 & 2 & Dores nas costas e quadris \\
\hline 8 & 0 & 1 & 2 & Sentir-se sem importância \\
\hline 9 & 0 & 1 & 2 & Sentir medo \\
\hline 10 & 0 & 1 & 2 & Náuseas, enjôos ou estômago ruim \\
\hline 11 & 0 & 1 & 2 & Dores musculares (dor no corpo) \\
\hline 12 & 0 & 1 & 2 & Sentir-se vigiado e comentado pelos outros \\
\hline 13 & 0 & 1 & 2 & Ter que conferir e reconferir o que fez \\
\hline 14 & 0 & 1 & 2 & Sentir medo de andar de ônibus, metrô ou trens \\
\hline 15 & 0 & 1 & 2 & Problemas para respirar \\
\hline 16 & 0 & 1 & 2 & Ondas de calor ou frio \\
\hline 17 & 0 & 1 & 2 & $\begin{array}{l}\text { Ter que evitar certas coisas, lugares ou atividades que o } \\
\text { amedrontam (dão medo) }\end{array}$ \\
\hline 18 & 0 & 1 & 2 & Um "branco" na cabeça (ter uma incapacidade \\
\hline
\end{tabular}




\begin{tabular}{|c|c|c|c|c|}
\hline & & & & momentânea de raciocinar ou lembrar-se de algo) \\
\hline 19 & 0 & 1 & 2 & Dormência ou formigamento em partes do corpo \\
\hline 20 & 0 & 1 & 2 & Sentir-se sem esperança sobre o futuro \\
\hline 21 & 0 & 1 & 2 & Dificuldade de concentração \\
\hline 22 & 0 & 1 & 2 & Sentir fraqueza em partes do corpo \\
\hline 23 & 0 & 1 & 2 & Sentir-se tenso ou travado \\
\hline 24 & 0 & 1 & 2 & Sentir peso nos braços e pernas \\
\hline 25 & 0 & 1 & 2 & $\begin{array}{l}\text { Sentir-se desconfortável quando as pessoas o } \\
\text { observam ou falam de você }\end{array}$ \\
\hline 26 & 0 & 1 & 2 & $\begin{array}{l}\text { Ter que repetir as mesmas ações como tocar, contar ou } \\
\text { lavar }\end{array}$ \\
\hline 27 & 0 & 1 & 2 & Ter desejos de quebrar ou destruir coisas \\
\hline 28 & 0 & 1 & 2 & Sentir-se muito acanhado ou preocupado com os outros \\
\hline 29 & 0 & 1 & 2 & $\begin{array}{l}\text { Sentir-se inquieto numa multidão, fazendo compras ou } \\
\text { no cinema }\end{array}$ \\
\hline 30 & 0 & 1 & 2 & Sentir que tudo é um esforço \\
\hline 31 & 0 & 1 & 2 & Ondas de terror ou pânico \\
\hline 32 & 0 & 1 & 2 & Envolver-se frequentemente em discussões \\
\hline 33 & 0 & 1 & 2 & Sentir nervosismo quando é deixado sozinho \\
\hline 34 & 0 & 1 & 2 & Sentir-se solitário mesmo quando está acompanhado \\
\hline 35 & 0 & 1 & 2 & $\begin{array}{l}\text { Sentir-se tão agitado que não é capaz de parar quieto } \\
\text { (de movimentar-se) }\end{array}$ \\
\hline 36 & 0 & 1 & 2 & Gritar ou atirar coisas \\
\hline 37 & 0 & 1 & 2 & Com medo de desmaiar em público \\
\hline 38 & 0 & 1 & 2 & Nunca se sentir próximo a outra pessoa \\
\hline 39 & 0 & 1 & 2 & Sentimentos de culpa \\
\hline 40 & 0 & 1 & 2 & A idéia de que há algo errado com sua mente \\
\hline
\end{tabular}




\section{ANEXO 4}

INVENTÁRIO DE ANSIEDADE DE BECK - BAI

Data: 1

Checado por:

Abaixo temos uma lista de sintomas comuns à ansiedade. Favor preencher cada item da lista cuidadosamente. Indique agora os sintomas que voce apresentou durante A ÚLTIMA SEMANA INCLUINDO HOJE Marque com um X os espaços correspondentes a cada sintoma.

\begin{tabular}{|c|c|c|c|c|}
\hline & 0 & 1 & 2 & 4 \\
\hline & Ausente & $\begin{array}{l}\text { Suave, não } \\
\text { me incontoda } \\
\text { multo }\end{array}$ & $\begin{array}{c}\text { Moderado, t } \\
\text { desagradivel } \\
\text { mas consigo } \\
\text { suportar }\end{array}$ & $\begin{array}{l}\text { Severo; } \\
\text { quase nabo } \\
\text { consigo } \\
\text { suportar }\end{array}$ \\
\hline \multicolumn{5}{|l|}{ 1. Dormencia ou formigamento } \\
\hline \multicolumn{5}{|l|}{ 2. Sensaçúes de calor } \\
\hline \multicolumn{5}{|l|}{ 3. Tremor nas pernas } \\
\hline \multicolumn{5}{|l|}{ 4. Incmoaz de relaxar } \\
\hline \multicolumn{5}{|l|}{ 5. Medo de acontecimentos ruins } \\
\hline \multicolumn{5}{|l|}{ 6. Contuso cu delirante } \\
\hline \multicolumn{5}{|l|}{ 7. Coração batendo forte er rapido } \\
\hline \multicolumn{5}{|l|}{ 8. Inseguro (a) } \\
\hline \multicolumn{5}{|l|}{ 9. Apavcrado (日) } \\
\hline \multicolumn{5}{|l|}{ 10. Nervaso (a) } \\
\hline \multicolumn{5}{|l|}{ 11. Sengaça de sufocamento } \\
\hline \multicolumn{5}{|l|}{ 12. Tremor nas maos } \\
\hline \multicolumn{5}{|l|}{ 13. Tremulo (a) } \\
\hline \multicolumn{5}{|l|}{ 14. Medo de perder o controle } \\
\hline \multicolumn{5}{|l|}{ 15. Dilculdade de respitar } \\
\hline \multicolumn{5}{|l|}{ 16. Modo de morter } \\
\hline \multicolumn{5}{|l|}{ 17. Assustado (a) } \\
\hline \multicolumn{5}{|c|}{ 18. Indigestäo ou desconforto abdominal } \\
\hline \multicolumn{5}{|l|}{ 19. Desmaios } \\
\hline \multicolumn{5}{|l|}{ 20. Rubor facial } \\
\hline 21. Sudorese (năo devido ao calor) & & & & \\
\hline
\end{tabular}




\section{ANEXO 5 \\ METÁFORAS ORIENTADAS PARA VALORES UTILIZADAS NA PESQUISA}

\section{1) Metáfora do esquiador}

Esquiar pendiente abajo puede proporcionar um ejemplo útil. Se siente como si, al inclinarse hacia adelante, usted fuera a perder el control y fuera a caer dando tumbos montaña abajo. Pero cuando se esquía, la única forma de mantener el control de su velocidad y su equilibrio, es, precisamente, ir pendiente abajo en lugar de echarse hacia atrás, aunque su inclinación natural sea ésa (Wilson \& Luciano, 2012).

Esquiar inclinado para baixo pode fornecer um exemplo útil. Sente-se como, ao inclinar-se para frente, você vai perder o controle e cair rolando montanha abaixo. Mas quando você esquia, a única maneira de manter o controle de sua velocidade e equilíbrio é precisamente inclinar-se ladeira abaixo, em vez de puxar para trás, mesmo que a sua inclinação natural seja essa (tradução livre).

\section{2) Metáfora do dentista}

Ir ao dentista proporciona outro ejemplo: si impulso natural es apartase com fuerza del torno, pero se usted hace eso, el daño podría ser peor. Como mínimo, no conseguirá arreglar sus dientes. Así que, ¿por qué entonces nos sentamos y permitimos que use el torno con nosotros? Seguro que no es porque nos guste ese instrumento. Nos sentamos porque sentarse ahí surte efecto (Wilson \& Luciano, 2012). 
Ir para o dentista fornece outro exemplo: seu impulso natural é afastar-se com força da broca, mas se você faz isso, o dano poderá ser pior. No mínimo, não conseguirá corrigir seus dentes. Assim, por que então sentamos e permitimos o uso da broca em nós? Claro que não é porque gostamos desse instrumento. Ficamos ali porquê sentar ali surte algum efeito (tradução livre).

\section{3) Metáfora da tartaruga}

...Imagínate una tortuga que se dirige hacia su cueva, donde están sus crias, el resto de tortugas... Pero la tortuga, cada vez que llueve, cuando soplaeEl viento, cuando se topa com piedras, se mete em su carapazón. A veces sale del caparazón, avanza un poco, pero en cuento ocurre a su alrededor algo inesperado (aparece una mariposa, ve un relámpago...) se mete dentro del caparazón... ¿Cres que de esta forma puede alcanzar lo que pretende? A lo mejor la alternativa es avanzar con todo el cuerpo fuera, en pleno contacto con el suelo, abierta a todo lo que pueda surgír en ese camino, notando todo lo que surja mientras avanza en dirección a sus crías, el resto de tortugas... Probablemente no le gusten muchas de las cosas que estén en ese camino, o tal vez sí, pero eso es absolutamente distinto de su compromiso de avanzar por el sendero... (Wilson \& Luciano, 2012).

Imagine uma tartaruga que vai para sua caverna, onde seus filhotes estão o resto das tartarugas... Mas a tartaruga, cada vez que chove, quando o vento sopra, quando topa com pedras, se enfia no seu casco. As vezes, sai do casco, avança um pouco, mas quando ocorre algo inesperado ao redor (uma mariposa aparece, vê um raio...) ela se enfia dentro do casco... Você acha que desta forma ela pode conseguir o que pretende? A melhor alternativa é avançar com o corpo inteiro para fora, em pleno contato com o solo, aberto a qualquer coisa que possa 
surgir nesse caminho, observando tudo o que surge enquanto ela avança em direção aos seus filhotes, as outras tartarugas... Provavelmente não gosta de muitas das coisas que estão na estrada, ou talvez sim, mas isso que é bastante diferente do seu compromisso de avançar ao longo do caminho... (tradução livre).

\section{4) Metáfora do acidente de avião}

Not so long ago, a plane landed seemingly miraculously on the River Hudson. All 155 people came out alive. What did those 155 people feel as they stood on dry land and realized what they'd been through? Would they all have had the same reaction? Absolutely not! Many would have felt very distressed and upset - they nearly died, and they might decide never to fly again as it's clearly too dangerous. Others might been overwhelming relief and happiness at having survived. Some might decide to live life to the full as a result of their experience, and be determined to fly even more. There could be 155 different reactions. Same event, different responses. It's not the event which causes our emotions, it's the meaning we give them. Those who interpreted the event as terrifyingly dangerous may feel very distressed, and be too anxious to fly again. Others will feel ecstatic as the meaning they gave the event was that they were incredibly lucky to survive (Ayres, 2009).

Não muito tempo atrás, um avião pousou aparentemente milagrosamente sobre o rio Hudson. Todas as 155 pessoas saíram vivas. O que essas 155 pessoas sentiram quando eles estavam em terra seca e perceberam o que tinha passado? Será que todos eles tiveram a mesma reação? Absolutamente não! Muitos poderiam ter se sentido muito angustiados e perturbados - eles quase morreram, e eles podem decidir nunca mais voar novamente, já que é 
claramente muito perigoso. Outros podem sentir um imenso alívio e felicidade por terem sobrevivido. Alguns podem decidir viver a vida ao máximo, como resultado de sua experiência, e serem determinados a voar ainda mais. Pode haver 155 reações diferentes. Mesmo evento, diferentes respostas. Não é o evento que faz as nossas emoções, é o significado que lhes damos. Aqueles que interpretaram o evento como terrivelmente perigoso podem se sentir muito angustiados, e estarem muito ansioso para voar novamente. Outros vão se sentir em êxtase, pois o significado que eles deram ao evento foi a de que eles eram incrivelmente sortudos de sobreviver (tradução livre).

\section{5) Metáfora da diretora de filme}

Picture your life as a movie. The first episodes are already shot. (Here I usually summarize what I know of the - usually difficult-salient moments of the clients life). Now the movie is going on. Imagine you are the director and you can direct an actor that plays your part. But you're a special kind of director with a limited power. You can't go to the screenplay writer and ask him to change the life events happening to you or direct the other characters to act like you'd want them to do. The only actor you can have an influence on is the one playing your part. You can have him/her play exactly like the person you dream to be. Figure out how you would want him/her to act, in that precise situation you are experiencing now. How would you instruct the actor to act if you want the continuation of the movie to resemble what you would like your life to be, or to show the father / spouse / colleague / etc. you would like to be? (Recuperado em 12 de maio de 2014, de http://contextualscience.org/your_life_as_a_movie) 
Imagine sua vida como um filme. Os primeiros episódios já foram gravados. (Aqui eu costumo resumir o que eu sei dos - geralmente difíceis - momentos marcantes da vida dos clientes). Agora o filme está acontecendo. Imagine que você é o diretor e você pode dirigir um ator que interpreta sua parte. Mas você é um tipo especial de diretor com um poder limitado. Você não pode ir para o roteirista e pedir-lhe para mudar os eventos da vida que acontecem com você ou dirigir os outros personagens para agir como você quer que eles façam. O único ator que você pode ter uma influência sobre é aquele que interpreta a sua parte. Você pode fazê-lo (a) interpretar exatamente como a pessoa que você sonha ser. Descubra como você gostaria que ele/ela agisse, precisamente na situação que você está enfrentando agora. Como você instruiria o ator agir se você quer que a continuação do filme se pareça com o que você gostaria que sua vida fosse, ou, para mostrar o pai / cônjuge / colega / etc como você gostaria de ser (tradução livre)?

\section{6) Um exemplo da metáfora do funeral}

Cierra los ojos, céntrate en el observador que hay en ti y date cuenta de que inhalas... y exhalas. Date cuenta de tu respiración... observa tu posición sentada..., nota que te das cuenta de que estás oyendo mi voz... y el ruido de fuera. Observa el movimiento de tu vientre según respiras... Nota que estás pensando..., las sensaciones que sientes..., contémplalas por unos segundos desde esa parte que hay en ti que te permite contemplar cualquier cosa que ocurre..., los que sientes..., lo que haces..., lo que piensas. Hay una parte en ti única y segura desde la que puedes observar todo lo que tu mente te da... Ahora, desde ese lugar que hay en ti, imagínate que has muerto y que asistes a tu entierro. Imagina que toda tu familia, todas las personas que quieres, están a tu alrededor. Céntrate en esa situación... Imagínate ahí y observa quiénes están a tu alrededor..., ¿quiéns están? (deje que el cliente lo diga). 
Ahora pon tu atención en tu hijo... y déjale decir lo que a ti gustaría que él dihera de ti... déjale hablar... ójelo, piensa que tienes poder y que puedes conseguir que diga lo que a ti más gustaría que dijese de ti... (el cliente, llorando, dice: "fue cariñosa conmigo, estaba conmigo, jugábamos y me ayudaba”)... ahora pon tú atención en tu marido, déjale decir lo que te gustaría que dijese. Déjale hablar... ("me cuidó y era amable conmigo, aunque se enfadaba...”)... También está alli tu madre. Piensa lo que a ti más te gustaría que dijera, qué querrías poner en sus labios si pudieras... ("estuvo a mi lado cuando estaba enferma, me ayudó, me quería...”). Escucha ahora tus hermanos, déhalos hablar sin reservas, lo que a ti gustaría que ellos dijesen, míralos y dime qué están diciendo sin reservas, déjales hablar... (llorando. “... no quiso”) Vamos a tu padre... Déjale habalar con lo que a ti más te gustaría que dijesen... ("era alegre, me ayudó cuando lo necesité...”) Dime, quién más hay acompañándote en tu entierro. ¿a quién ves?... (“mis compañeros de trabajo...”). Déjales hablar con lo que a ti más gustaría que dijesen... ("siempre fue une buena compañera y trabajadora”). ¿Hay alguien más? (“no”). Ahora, nuevamente, date cuenta de que estamos aquí, tu y yo en esta habitación..., nota la postura sentada, tus brazos y piernas apoyados..., aprecia desde ese lugar que siempre está detrás, de lo que sientes, que te permite observar que tus ojos están cerrados..., de los pensamientos que ahora tienes..., que se da cuenta de que estás aquí escuchando mi voz... Desde esa posición contempla tus pensamientos, contempla cómo fluyen, nota cualquier cosa que te dé tu mente sin hacer nada... contémplalos cómo observas el movimiento del mar... (deje el cliente unos minutos). Cundo quieras abre los ojos (silencio prologando) (...) (Wilson \& Luciano, 2012).

Feche os olhos, concentre-se no observador que há em você e se dê conta de que você inala ... e expire. Perceba sua respiração sua respiração... Observe a sua posição sentada ... note que você percebe que você está ouvindo a minha voz ... e o ruído de fora. Acompanhe o 
movimento do seu corpo enquanto você respira... Note que você está pensando ..., as sensações que você sente ... contemple elas por alguns segundos desde essa parte que há em você permite que você veja qualquer coisa... o que você sente ..., o que você faz ... o que você acha. Há uma parte você única e fixa desde que você pode ver tudo o que a sua mente lhe oferece... Agora, a partir desse lugar que há em você, imagine que você morreu e que você assisti o seu funeral. Imagine que toda a sua família, todas as pessoas que você quiser, estão todos ao seu redor. Concentre-se na situação... Imagine-se lá e veja quem está ao seu redor ... Quem está na cena? (Deixe que o cliente diga). Agora, coloque sua atenção em seu filho ... e deixe-o dizer o que você gostaria que ele dissesse à você ... deixe-o falar ... olhe-o, pense que e você tem o poder e que você pode levá-lo a dizer o que você mais gostaria que ele te dissesse ... (o cliente, chorando, disse: "Foi carinhosa comigo, estava comigo, jogamos e me ajudou") ... agora coloque sua atenção sobre o seu marido, deixe-o dizer o que você gostaria que ele lhe dissesse. Deixe-o falar ... ("me cuidou e foi amável comigo, embora estava com raiva...") ... Também está ali sua mãe. Pense no que você mais gostaria que ela lhe dissesse, o que você gostaria de colocar em seus lábios se você pudesse ... ("Ela ficou ao meu lado quando eu estava doente, me ajudou, eu queria..."). Ouça agora os seus irmãos, deixe-os falar sem rodeios o que você gostaria que eles dissessem, olhe para eles e me diga o que estão dizendo, sem reservas, deixe-os falar ... (chorando. "... Não quero") Vamos ao seu pai ... Deixe-o falar, deixe-o dizer o assim você gostaria que ele lhe dissesse ... ("ela era feliz, me ajudou quando eu precisei ...") Então, quem mais está acompanhando você em seu funeral. Quem você vê? ... ("Meus colegas de trabalho ..."). Deixá-los falar o que você mais quer que eles lhe digam... ("Ele sempre foi uma boa companheira e trabalhadora"). Há mais alguém? ("Não"). Agora, mais uma vez, note que estamos aqui, você e eu, neste quarto ... observe a sua postura sentada, os braços e as pernas apoiadas ... aprecie o lugar que está sempre por detrás, do que você sente, que te permite observar que seus olhos estão fechados ... Dos pensamentos 
que você tem agora... Note que que você está aqui ouvindo a minha voz ... a partir desta posição, contemple seus pensamentos, como eles fluem, observe qualquer coisa que vier a sua mente sem fazer nada contemplá-los ... Observe eles como olha os movimentos do mar ... (deixe o cliente falar por alguns minutos). Quando você quiser pode abrir os olhos (silêncio prolongado) (...) (tradução livre). 


\section{ANEXO 6 \\ RESUMO DE CATEGORIAS DO EIXO 1 DO SiMCCIT - Sistema Multidimensional de Categorização de Comportamentos na Interação Terapêutica}

\section{Categorias do Eixo I: Respostas Verbais para o TERAPEUTA.}

Terapeuta Solicita Relato

(SRE)

Solicita ao cliente descrições a respeito de ações, eventos, sentimentos ou pensamentos.

Terapeuta facilita o relato do cliente (FAC)

Verbalizações curtas ou expressões paralingüísticas.

Terapeuta demonstra empatia (EMP)

Acolhimento, aceitação, cuidado, entendimento, validação da experiência ou sentimento do cliente.

Terapeuta Fornece Informações (INF)

Relata eventos ou informa o cliente sobre eventos, que não o comportamento do cliente ou de terceiros.

Terapeuta Solicita Reflexão (SRF)

Solicitação para que o cliente pense, reflita, estabeleça ou relate relações a respeito de eventos.

Terapeuta Recomenda ou solicita a execução de ações, tarefas ou técnicas (REC)

Sugestão de alternativas de ação ou solicitação que cliente se engaje em ações ou tarefas. 
Terapeuta interpreta (INT)

Relações causais e/ou explicativas ou padrões a respeito do comportamento do cliente ou de terceiros.

Terapeuta aprova ou concorda com ações ou avaliações do cliente (APR)

Avaliação ou julgamento favorável.

Terapeuta reprova ou discorda de ações ou avaliações do cliente (REC)

Avaliação ou julgamento desfavorável.

Outras verbalizações do terapeuta (OUTRAS VOCAL TERAPEUTA)

Verbalizações do terapeuta não-classificáveis nas categorias anteriores

Terapeuta permanece em silêncio (T SILÊNCIO)

Resposta verbal do tipo estado é encerrada sem que uma nova resposta verbal do tipo estado do mesmo falante seja iniciada.

Registro Insuficiente (INSUFICIENTE TERAPEUTA)

Categorias do Eixo I: Respostas Verbais para o CLIENTE.

Cliente solicita informações, opiniões, asseguramento, recomendações ou procedimentos (SOL)

Pedidos ou questões ao terapeuta.

Cliente relata eventos (REL)

Descreve ou informa a ocorrência de eventos. 
Cliente relata melhora ou progresso terapêutico (MEL)

Relata mudanças satisfatórias.

Cliente formula metas (MET)

Descreve projetos, planos ou estratégias para a solução de problemas.

Cliente estabelece relações entre eventos (REL)

Estabelece relações causais e/ou explicativas entre eventos.

Cliente relata concordância ou confiança (CON)

Julgamento ou avaliação favorável, relato de satisfação, esperança ou confiança.

Cliente se opõe, recusa ou reprova (OPO)

Discordância, julgamento ou avaliação desfavorável.

Outras verbalizações do cliente (OUTRAS VOCAL CLIENTE)

Não classificáveis nas categorias anteriores.

Cliente permanece em silêncio (C SILÊNCIO)

Idem T Silêncio.

Registro Insuficiente (INSUFICIENTE CLIENTE) 